Fossil Enengy Phogram

\title{
Fossil Energy Program Progress Report for August 1979
}

\author{
L. E. McNeese
}

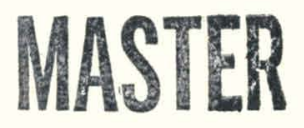

\section{OAK RIDGE NATIONAL LABORATORY} OPERATED BY UNION CARBIDE CORPORATION - FOR THE DEPARTMENT OF ENERGY 


\section{DISCLAIMER}

This report was prepared as an account of work sponsored by an agency of the United States Government. Neither the United States Government nor any agency Thereof, nor any of their employees, makes any warranty, express or implied, or assumes any legal liability or responsibility for the accuracy, completeness, or usefulness of any information, apparatus, product, or process disclosed, or represents that its use would not infringe privately owned rights. Reference herein to any specific commercial product, process, or service by trade name, trademark, manufacturer, or otherwise does not necessarily constitute or imply its endorsement, recommendation, or favoring by the United States Government or any agency thereof. The views and opinions of authors expressed herein do not necessarily state or reflect those of the United States Government or any agency thereof. 


\section{DISCLAIMER}

Portions of this document may be illegible in electronic image products. Images are produced from the best available original document. 


\section{Printed in the United States of America. Available from National Technical Information Service \\ U.S. Department of Commerce \\ 5285 Port Royal Road, Springfield, Virginia 22161 \\ NTIS price codes-Printed Copy: A06 Microfiche A01}

This report was prepared as an account of work sponsored by an agency of the United States Government. Neither the United States nor any agency thereof, nor any of their employees, makes any warranty, expressed or implied, or assumes any legal liability or responsibility for any third party's use or the results of such use of any information, apparatus, product or process disclosed in this report, or represents that its use by such third party would not infringe privately owned rights. 
Contract No. W-7405-eng-26

FOSSIL ENERGY PROGRAM

PROGRESS REPORT FOR AUGUST 1979

L. E. McNeese

Program Director

Date Published: October 1979

OAK RIDGE NATIONAL LABORATORY

uak Rluge, Tenncesee 37830 operated by UNION CARBIDE CORPORATION

for the DEPARTMENT OF ENERGY

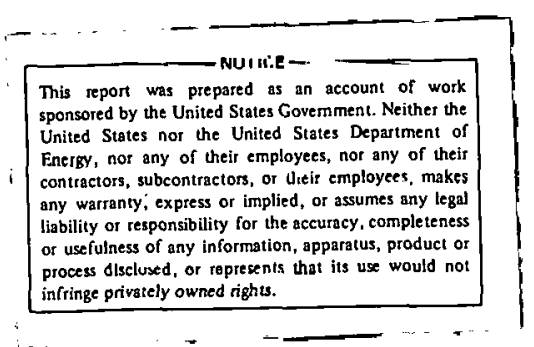




\section{THIS PAGE}

\section{WAS INTENTIONALLY LEFT BLANK}




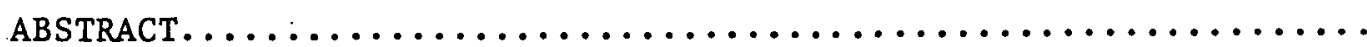

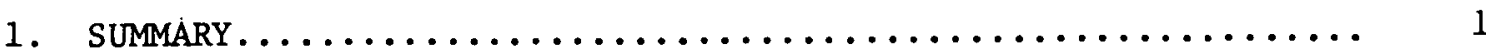

2. COAL CONVERSTON DEVELOPMENT..................... 7

2.1 Physical Properties of Coal Liquids................ 7

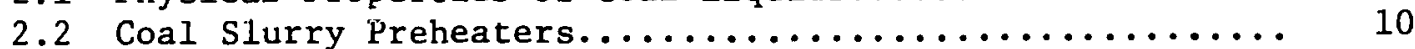

2.3 New Liquefaction 'lechnology.................... 10

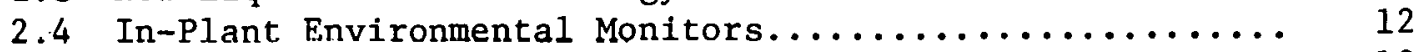

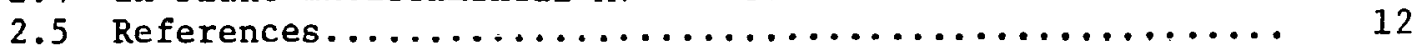

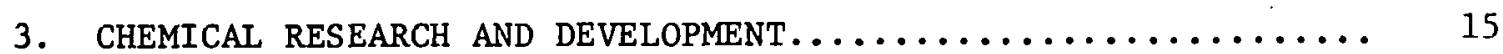

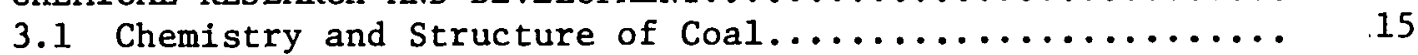

3.2 In-Process Tracer Studies of Coal Liquefaction

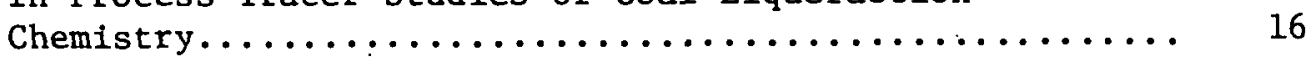

4. MATERIALS ENGINEERING.......................... 17

4.1 Pressure Vessel and Piping Materials.............. 17

4.2 Fossil Energy Welding and Cladding Development......... 17

4.3 Fireside Corrosion of AFBC Heat Exchanger Materials..... 18

4.4 Failure Prevention and Analysis.................. 18

4.5 Materials for $\mathrm{ZnCl}_{2}$ Liquefaction Process.............. 19

4.6 Materials to Resist Stress-Corrosion Cracking in Coal

Liquefaction Pilot Plants...................... 19

4.7 Development of Advanced $9 \mathrm{Cr}-1$ Mo Structural Steel...... 20

1.8 Ceramic Recuperator (Heat Fxr.hangers).............. 21

5. COMPONENT AND PROCESS EVALUATION STUDIES............... 23

5.1 Coal Feeder Test Program........................ 23

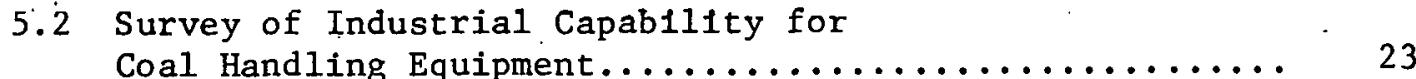

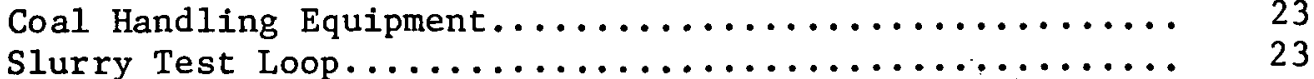

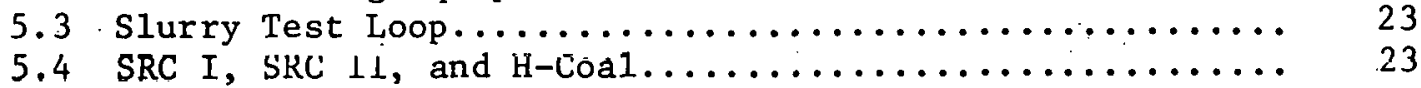

6. ENGINEERING STUDIES AND TECHNTCAL SUPPORT.............. 24

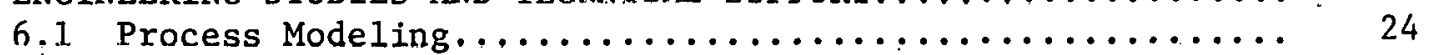

6.2 Coal Liquefaction. Advanced Research Digest............ 25

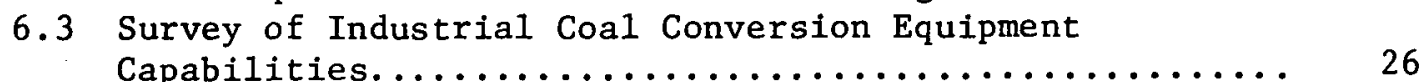

6.4 Environmental Controls for Low-Btu Gasification........ 27

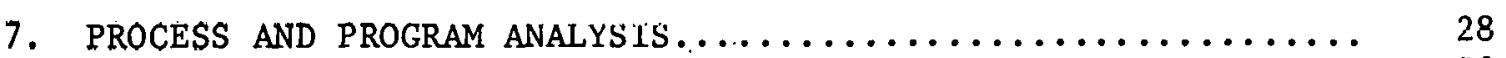

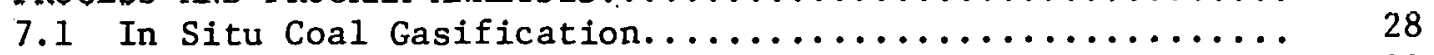

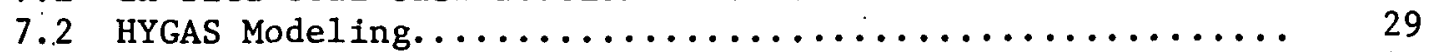

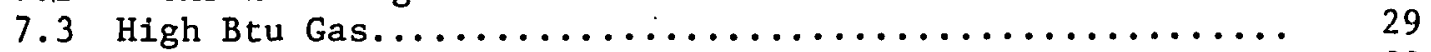

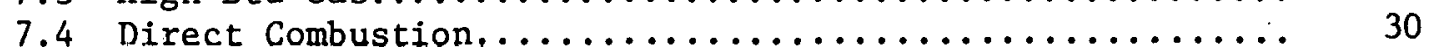

7.5 Advanced Power Conversion Systems................. 31

7.6 Fuel-Grade Methainol Synthesis Technology Asscssment..... 31.

7.7 Liquefaction Technology Assessment (LTAS)........... 33 
8. FOSSIL ENERGY ENVIRONMENTAL PROJECT............... 35

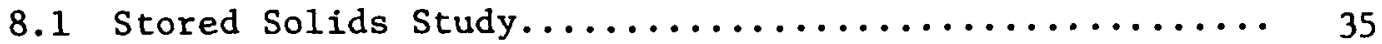

8.2 Processing of Coal Conversion Wastes for

Disposal and Resource Recovery............... 36

8.3 Coal Conversion Demonstration Projects............ 36

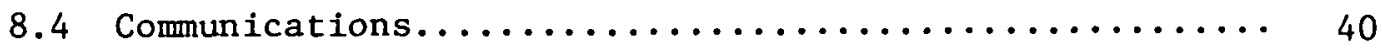

8.5 Milestones........................... 40

9. MAGNETIC PREPARATION OF DRY CRUSHED COAL............. 41

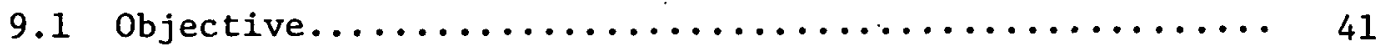

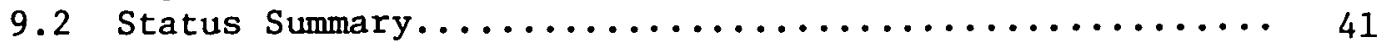

10. ATMOSPHERIC FLUIDIZED BED COAL COMBUSTOR

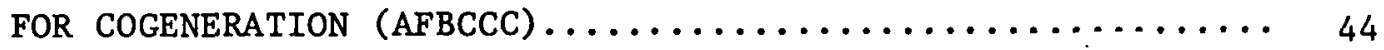

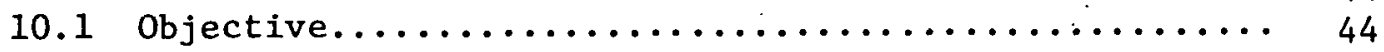

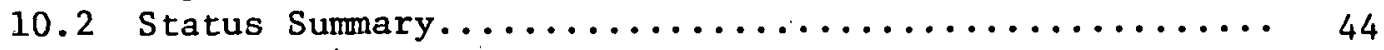

11. TENNESSEE VALLEY AUTHORITY (TVA) FLUIDIZED BED

COMBUSTION (FBC) DEMONSTRATION PLANT PROGRAM

TECHNICAL SUPPORT......................... 46

11.1 AFBC Technology Support - Task $2 \ldots \ldots \ldots \ldots \ldots \ldots \ldots \ldots . \ldots \ldots$

$11.24 \times 4$ Cold Flow Model - Task 3............... 47

11.3 AFBC Modeling and Simulation - Task $4 \ldots \ldots \ldots \ldots \ldots \ldots . \ldots 48$

11.4 AFBC Bench Scale Facility - Task $5 \ldots \ldots \ldots \ldots \ldots \ldots \ldots . \ldots 8$

11.5 Assessment of the State-of-the-Art of

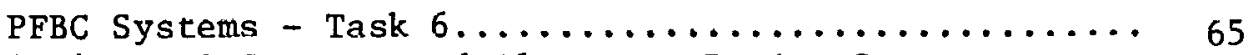

11.6 Analytical Support and A1ternate Design Concepto

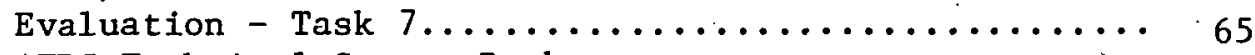

11.7 AFBC Technical Source Book

und R\&D Evaluation - 'l'isk $. \ldots \ldots \ldots \ldots \ldots \ldots \ldots \ldots \ldots, 69$

11.8 Materials Support for TVA Pilot

and Dehionstration AFBC Plants - Task $9 \ldots \ldots \ldots \ldots \ldots .71$

11.9 Dynamic Modeling of the TVA Fluidized Bed Combustion

Pilot Plant - Task 10...................... 74

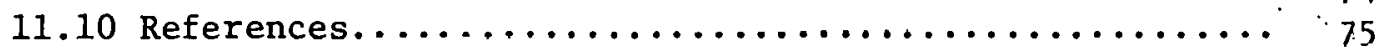

12. COAL COGENERATION/DISTRICT HEATING PLANT ASSESSMENT....... 76

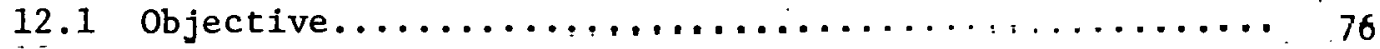

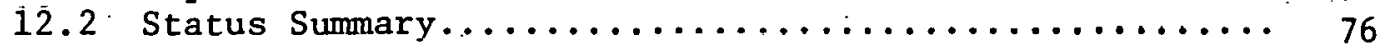

13. TECHNICAL SUPPORT TO MAJOR LIQUEFACTION PROJECTS ......... 78

13.1 SkC Demonstration Plants Design Review........... 78

13.2 Direct Liquefaction R\&D Review................ 79

13.3 SRC Source Data Book...................... 80

13.4 SRC Envi.ronmental Support................. 81

13.5 SRC Net Energy Analysis.................... 83

$13.6 \mathrm{H}$-Coal Materials and Technology Review............ 83

$13.7 \mathrm{H}$-Coal Quality Assurance Assistance.............. 86

13.8 References for Section $13 \ldots \ldots \ldots \ldots \ldots \ldots \ldots \ldots \ldots . \ldots \ldots$ 
PREVIOUS REPORTS IN THIS SERIES

\author{
ORNL/TM-5044, Progress Report for August 1974 \\ ORNL/TM-5045, Progress Report for September 1974 \\ ORNL/'IM-5046, Progress Keport for October 1974 \\ ORNL/TM-4787, Progress Report for November 1974 \\ ORNL/TM-4796, Progress Report for December 1974 \\ ORNL/TM-4850, Progress Report for January 1975 \\ ORNL/TM-4873, Progress Report for February 1975 \\ ORNL/TM-4892, Progress Report fur March 1975 \\ ORNL/TM-4946, Progress Report for April 1975 \\ ORNI./TM-4966, Progress Report for May 1975 \\ ORNL/TM-5010, Progress Report for June 1975 \\ ORNL/TM-5037, Progress Report for July 1975 \\ ORNL/TM-5092, Progress Report for August 1975 \\ ORNL/TM-5124, Progress Report for September 1975 \\ ORNL/TM-5186, Progress Report for October 1975. \\ ORNL/TM-5214, Progress Report for November 1975 \\ ORNL/TM-5246, Progress Report for December 1975 \\ ORNL/TM-5301, Progress Report for January 1976 \\ ORNL/TM-5321, Progress Report for February 1976 \\ ORNL/TM-5430, Progress Report for March 1976 \\ ORNL/TM-5479, Progress Report for April 1976 \\ ORNL/TM-5532, Progress Report for May 1976 \\ ORNL/TM-5595, Progress Report for June 1976 \\ ORNL/TM-5611, Progress Report for July 1976 \\ ORNL/TM-5654, Progress Report for August 1976 \\ ORNL/TM-5674, Progress Report for September 1976 \\ ORNL/TM-5717, Progress Report for October 1976 \\ ORNL/TM-5752, Progress Report for November 1976 \\ ORNL/TM-5770, Progress Report for December 1976 \\ ORNL/TM-5819, Progress Report for January 1977 \\ ORNL/TM-5858, Progress Report for February 1977 \\ ORNL/TM-5883, Progress Report for March 1977 \\ ORNL/TM-5932, Progress Report for Apr11 1977 \\ ORNL/TM-5980, Progress Report for May 1977 \\ ORNL/'IM-6003, Progress Report for June 1977 \\ ORNL/TM-6038, Progress Report for July 1977 \\ ORNL/TM-6066, Progress Report for August 1977 \\ ORNL/TM-6104, Progress Report for September 1977 \\ ORNL/TM-6137, Progress Report for October 1977 \\ ORNL/TM-6217, Progress Report for November 1977 \\ ORNL/TM-6262, Progress Report for December 1977 \\ ORNL/TM-6274, Progress Report for January 1978 \\ ORNL/TM-6329, Progress Report for February 1978 \\ ORNL/TM-6385, Progress Report for March 1978 \\ ORNL/TM-6386, Progress Report for April 1978 \\ ORNL/TM-6454, Progress Report for May 1978 \\ ORNL/TM-6489, Progress Report for June 1978 \\ ORNL/TM-6518, Progress Report for July 1978
}


PREVIOUS REPORTS IN THIS SERIES (CONTINUED)

ORNL/TM-6592, Progress Report for August 1978

ORNL/TM-6630, Progress Report for September 1978

ORNL/TM-6666, Progress Report for October 1978

ORNL/TM-6682, Progress Report for November 1978

ORNL/TM-6767, Progress Report for December 1978

ORNL/TM-6815, Progress Report for January 1979

ORNL/TM-6829, Progress Report for February 1979

ORNL/TM-6886, Progress Report for March 1979

ORNL/TM-6923, Progress Report for April 1979

ORNL/TM-6928, Progress Report for May 1979

ORNL/TM-6997, Progress Report for June 1979

ORNL/TM-7031, Progress Report for July 1979 
FOSSIL ENERGY PROGRAM REPORT FOR AUGUST 1979

\begin{abstract}
This report - the sixty-first of a series - is a compendium of monthly progress reports for the ORNL research and development programs that are in support of the increased utilization of coal and other fossil fuel alternatives to o1l and gas as sources of clean energy. The projects reported this month include those for coal conversion development, materials engineering, a coal equipment test program, an atmospheric fluid bed combustor for cogeneration, engineering studies and technical support, process and program analysis, environmental assessment studies, magnetic beneficiation of dry pulverized coal, technical support to the TVA fluid bed combustion program, coal cogeneration/district heating plant assessment, chemical research and development, and technical support to major liquefaction projects.
\end{abstract}

\title{
1. Summary
}

L. E. McNeese

Highlights of our progress in August are as follows:

Coal Conversion Development - Elemental analyses and solvent fractionation results are presented for three product slurry samples taken during the Coal Liquid Flow System run reported last month. Computer interfacing equipment was installed for pipeline viscometer rheological characterization data logging. With this information the computer generates a flow curve immediately after a data set is completed. The low conversions when biphenyl ether is reacted with coal support the hypotherized reaction sequence for the reaction of phenol with coal. These ideas will be tested further in planned reactions between biphenyl ether and coal whose hydrogen-donating components have been removed by chloroform extraction. Fabrication of the two portable PNA spotters for the field testing program continued during August. The units are expected lo be teady for the field evaluation by octobcr 1 .

Chemical research and development - A simple free-radical model for the thermolysis of bibenzyl in the presence of $\alpha$-naphthol appears insufficient to account for the observed results; further data will be necessary to clarify the unanticipated chemistry occurring in this model system for interaction of radicals with the phenolic functional groups in coal. The synthesis of $1-{ }^{11} \mathrm{C}$-tetralin $(22 \mathrm{mCi})$ for the anticipated in-process tracer study of coal liquefaction has been completed. 
Materials Engineering - The study of the effect of coal conversion environment on the mechanical properties of pressure vessel steel was continued. A 400-h exposure of samples with different heat treatment histories to hydrogen at $1500 \mathrm{psi}$ and $490^{\circ} \mathrm{C}$ is nearing completion. In the task to develop techniques for weld overlay cladding with type $320 \mathrm{Cb}$ stainless steel, a subcontract was initiated with Sandvik, Inc. to produce strip clad weld samples for evaluation. Recent activities on materials for atmospheric fluidized-bed combustors have concentrated on preparation of a materials test plan for the Boiler Materials Test Apparatus (BMTA). A draft version of the test plan was provided to DOE-ORO and DOE-METC for review. Failure analyses for coal liquefaction plants continued. Chemical analyses of scale on corroded trays removed from the Wilsonville fractionation column confirmed that the deposit is primarily nickel sulfide. The results of examination of the Johnson screen distributor plate from the METC AFBC are also reported. Work continued on setting up the 1.oop for exposing materials to the recuperator environment of the $\mathrm{ZnCl}_{2}$ Liquefaction Process. In the study of materials to resist stress corrosion cracking in coal liquefaction pilot plants, exposure of U-bend specimens at both the Wilsonville and Fort Lewis SRC pilot plants continued. Assembly of laboratory equipment for performing stress-corrosion cracking studies is almost complete. The development of modified $9 \mathrm{Cr}-1$ Mo structural steel continued. Mechanical property characterization, fabrication, weldability, and steam corrosion studies continued on experimental heats to better define the desired chemistry of the commerical. heats to be melted in September for the Fossil Energy Program. In the task to develop ceramic recuperators, work was continued on preparing a report summarizing the results of the three subcontracts completed earlier this year to assess the economic application, design considerations, and materials availability for ceramic heat exchangers. Work continued on schedule to install the Ceramic Recuperator Analysis Facility on the Refractory Test Facility to permit testing of candidate ceramic heat exchanger elements.

Component and Process Evaluation 3tudies - The Coal Handling Survey report has been typed in final form and was in proofreading at the end of the reporting period. A successful shakedown run of the slurry test loop was completed, using water at low pressure.

Engineering Studies and Technical Support - A CDC compatible form of ORNL's Double Precision Converter program has been developed and will.1 be forwarded to Lehigh University for their use in developing computer models of coal conversion processes. Documentation of this program for general use is also in progress.

Proceos and Program Analysis - The final report of our 1977 technical evaluation of in situ coal gasification, Process Designs and Economic Evaluations for the Linked Vertical Well In Situ Coal Gasification Process (ORNL-5341), was published and distributed on August 22. This report detailed three conceptual process designs and cost estimates which. illustrated the following potential applications of underground coal gasification: (1) a 900-MW(e) combined-cycle electric generating plant fired by. low-Btu gas, (2) a substitute natural gas (SNG) plant producing $155 \mathrm{MMscfd}$ of $954 \mathrm{Btu} / \mathrm{scf}$ gas, and (3) a synthesis gas plant producing 388 MMscf of gas suitable for further conversion to chemicals. 
Fossil Energy Environmental Project - In the Stored Solids Study, column leaching studies using varfable residence times were initiated on Grace/Ebasco/Texaco solid waste. In the Resource Recovery work, three gasifier wastes have been subjected to direct leach with nitric, sulfuric and hydrochloric acids. From these preliminary tests and in terms of recoveries of aluminum and iron, hydrochloric acid appears to be the acid of choice.

A considerable effort was expended in justifying our environmental information needs for the Grace EIS. The ICGG Scoping Meeting was held in Cutler, Illinois, on August 15. On the CoNOco project, a draft Implementation Plan and Notice of Intent was prepared and delivered to DOE. EIS related work was carried out on all six demonstration projects: SRC-I, SRC-II, Grace, MLGW, CONOCO, and ICGG.

Magnetic Preparation of Dry Crushed Coal - Sala Magnetics is converting their carousel to dry transport, and arrangements with TVA for coal have been finalized in preparation for the continuous separation testing.

Samples have been separated using induced roll magnets, and we are awaiting chemical analysis on the samples.

The contract with Powell Construction Company has been negotiated.

Additions to our analytical magnet mode have and are being made.

Atmospheric Fluidized Bed Coal Combustor for Cogeneration (AFBCCC) The eval.uation of the CCC proposals was completed early this month. A team composed of Westinghouse, Babcock and Wilcox, and Stone and Webster was selected by the eval,nation team to receive the subcontract award. A meeting was held with DOE-FFU Division in Washington on August 10, and ORNL was given approval to negotiate a subcontract with the Westinghouse team.

TVA FBC Demonstration Plant Program - In AFBC technical support, a review of proposals from Babcock \& Wilcox and Combustion Engineering to design and build an AFBC pilot plant for TVA has been initiated and practically completed this past month. The review was undertaken by a multidiscipline team. A preliminary summary letter was drafted and submitted to TVA which included 43 comments and discussions on a number of issues of specific concern to TVA.

Tests were conducted to investigate the effects of slumping a portion of the bed and continuing operation of the remainder. Observations were made to study mixing between the active and slumped portions, fluidizing air bypass through the slumped section, elutriation from the fluidized section, deposit in the slumped section, and maximum buildup of the slumped bed. A film technical report on this program has been completed and will be presented to TVA program personnel in September. 
In AFBC modeling, the ORNL attrition-elutriation model was used to predict the performance of the $B \& W 6 \times 6$ AFBC based on test series 5 and 6 performed in November 1978 and February 1979, respectively. The differential particle size distribution for the feed material in the bed and for the elutriated solids are presented. These results predict that $21.1 \mathrm{gm} / \mathrm{sec}(22 \%)$ of inlet limestone solids are blown out of the cell and that about half of this $(11.6 \mathrm{gm} / \mathrm{sec}$ or $12 \%$ ) is caused by attrition. Preliminary estimates from experimental data indicate that roughly $4 \%$ of the bed weight is attrited in an hour. The calculations based on the $4 \%$ estimate yield an attrition rate for the overall bed of $27.11 \mathrm{gm} / \mathrm{sec}$, as compared to $11.6 \mathrm{gm} / \mathrm{sec}$ predicted by the model. In order to resolve this disagreement, the data from the $B \& W$ experimental series 5 and 6 were analyzed and correlated. Sperifically, the total rate of liüeslune sollds elutriated and the rate due to attrition were calculated from the data.

In the AFBC Bench Scale Facility, ten coal combustion runs totaling 36 hours were completed during the month. Superficial velocities of 4 , 5 , and $6 \mathrm{ft} / \mathrm{sec}$ were investigated for sulfur capture. Test resulis indicate that for a superficial velocity of $6 \mathrm{ft} / \mathrm{sec}$ and a bed temperature of $1550^{\circ} \mathrm{F}$, a calcium to sulfur mole ratio of about $4.5: 1$ is required in order to achieve $90 \%$ sulfur capture. The carbon burnup for this series uf tests was about $83 \%$. This is reasonable when shallow beds with no recycle of char are considered. For the $5 \mathrm{ft} / \mathrm{sec}$ series of tests, bed temperatures were held to $1500^{\circ} \mathrm{F}$. A calcium to sulfur mole ratio of just over $3: 1$ is required for $90 \%$ sulfur capture. Carbon burnup was about $86 \%$.

In AFBC technical and economic evaluations, we have completed performance analyses for 16 cases. Preliminary concluoions for the cases studied are:

- Combustion above the hed can have a major impact on the location and area of the heat transfer surfacec.

- Bed depth is very important in combustion efficiency and sulfur capture. Reducing the static bed depth from 6 to $3 \mathrm{ft}$ reduced combustion efficiency about $3 \%$ and increased limestone requireWenls almost 50\%.

- Velocity changes have a relatively minor effect on operation. The primary result of higher velocity is greatly reduced plan area.

- Reducing excess air inrreases overall boilcr efficiency, iucruudco the maximum freeboard temperature, and decreases combustion efficiency. Cutting excess air from $20 \%$ to $3 \%$ increased boiler efficiency by $0.65 \%$, increased the maximum freeboard temperature from $1945^{\circ}$ to $2003^{\circ} \mathrm{F}$, and decreased main bed combustion efficienry from $94: 8 \%$ to $94: 0 \%$.

Overall, bed depth and freeboard combustion appear to be the most important parameters evaluated to date. Economic evaluations are now being completed for the first 16 cases. 
In the AFBC technical source book, heat transfer correlations were reviewed this month for immersed tube bundles inside the fluidized bed. Certain correlations gave reliable estimates for the heat transfer coefficient. These are defined in detail in the body of the report.

Other considerations affecting the heat transfer coefficient that have been reviewed this month are:

1. flattening the tubes,

2. adding fins on tubes,

3. slanting the tubes, and

4. particle size.

The first version of the fluidization section is almost complete. The fluidization section will be reviewed with Henry Withers of TVA during the coming month.

In materials support, the proposals submitted to TVA by Babcock and Wilcox (B\&W) and Combustion Engineering (CE) for the AFBC pilot plant were reviewed in terms of materials requirements and selections. In general, neither bidder adequately addressed potential problem areas with respect to materials; however, this is primarily a reflection of a lack of definitive information regarding response of materials to potential environments in an AFBC. Metallographic examinations show that, in general, the sulfate deposits are unusually thick on the chrome-moly steels, probably ciaused by the relatively low exposure temperature and high thermal conductivity of the ferritic steels. Beneath the oxide-metal. interface are numerous small inclusions of manganese sulfides that are exposure related. The stainless steels show much thinner sulfate deposits, thin continuous oxide scale, and subsurface sulfide inclusions to depths of about $20 \mu \mathrm{m}$. At this time, it is not apparent that the corrosion of any specimen is positional or orientation dependent.

While the observation of corrosion features to depths of about $20 \mu \mathrm{m}$ in a 1000-h test might seem alarming, it should be noted that other tests have indicated that corrosion of these and similar alloys in AFBC's is initially rapid, but decreases with time. The samples removed at the end of the second 1000-h have now been received and will be examined in the near future.

In the dynamic modeling task, a portion of this month was devoted to reviewing the vendors' proposals for the TVA pilot plant. A number of observations and recommendations related to the instrumentation and controls section were submitted to TVA for consideration. As time permitted, development of an $\mathrm{SO}_{2}$ capture submodel for the dynamic modeling work was undertaken. Details will be reported next month, when the submodel is expected to be completed. 
Coal Cogeneration/District Heating Plant Assessment - In early August, we initiated the contracting procedure with the St. Paul District Heating Development Company. The goal is to have the contract in place by October 1, 1979 .

M. A. Karnitz attended a DOE D1str1ct Heating Task Force Meeting on August 7 in Washington, D.C.

Preliminary performance curves for the two closed-cycle gas turbine systems for district heating were derived.

Technical support to major liquefaction projects - An intensive review and evaluation of the Phase 0 deliverables for the SRC-I and SRC-II projects was made during the month of August. Phase 0 documents were received on August 3, and a final draft report of our review and evaluation results was transmitted to DOE-ORO on August 28. A major part of this effort was devoted to an assessment of technical risks and onvironmental concerns. Work un uller SRC lasks was substantially reduced during August because of the large review and evaluation effort.

The H-Coal Materials and Technology Task Force met with ASFI representatives on August 2 in Catlettsburg, Kentucky. The purpose of the meeting was to coordinate the work of the Task Force with similar activities being performed by ASFI. A revised work statement on action plans for the Task Force was completed and submitted to DOE-ORO. Assistance in quality assurance activities has continued for the H-Coal Pilot Plant Project. 


\section{COAL CONVERSION DEVELOPMENT}

J. R. Hightower, Jr.

Coal conversion development activities are carried out in the Chemical Technology Division. This section discusses four projects conducted for the Division of Fossil Fuel Processing -- Physical Properties of Coal Liquids, Coal Slurry Preheaters, New Liquefaction Techniques, and In-Plant Environmental Monitors. The project conducted for the Division of Fossil Fuel Extraction -- Experimental Engineering Support for In-Situ Gasification Processes -- has been completed.

\subsection{Physical Properties of Coal Liquids}

G. E. Oswald and E. L. Youngblood

Physical properties (viscosity, density, thermal conductivity, and heat capacity) of both coal-solvent slurries and solids-free, coalderived liquids will be measured at typical processing conditions, up to $31 \mathrm{MPa}$ (4500 psig) hydrogen pressure and $810 \mathrm{~K}\left(1000^{\circ} \mathrm{F}\right)$ in a bench-scale, continuous flow system, the system includes a slurry preheater section and a hydrogenation reactor to simulate processing conditions prior to physical property measurement. Immediately after physical property measurement, the test fluids will be quenched and sampled for chemical characterization. Physical properties will be correlated with chemical characteristics of the test liquid.

'The operation of the coal liquids flow system (CLFS) during this report period, product slurry analytical results, and plans for future work are discussed in this section.

\subsubsection{Work accomplished}

Two weeks of operator training sessions were completed. Table 2.1 contains process operating conditions for run 7-29-79 reported last month. Table 2.2 presents elemental analyses and solvent fractionation results for three product slurry samples taken during this run. The inline samples were taken during the run as noted; the composite sample is from the total product slurry collected over the duration of the run. Correspondence between the inline and composite samples is quite good, indicating rapid attainment nf steady operating conditions. As reported last month, offgas composition reached steady state 1.5 hours after slurry feed was initiated. THF conversion and liquid product fractionation (soxhlet extraction) agree very well with product slurries produced in the Preheater Studies in Coal Liquefaction project at Sandia Laboratories ${ }^{1}$ using a 33 wt \% Illinois No. 6 coal in SRC II heavy distillate slurry.

Liquid product fractionation by soxhlet extraction will be a correlating parameter for future slurry rheological characterizations and other physical property measurements. 
Table 2.1. Process conditions summary, run 7-29-79

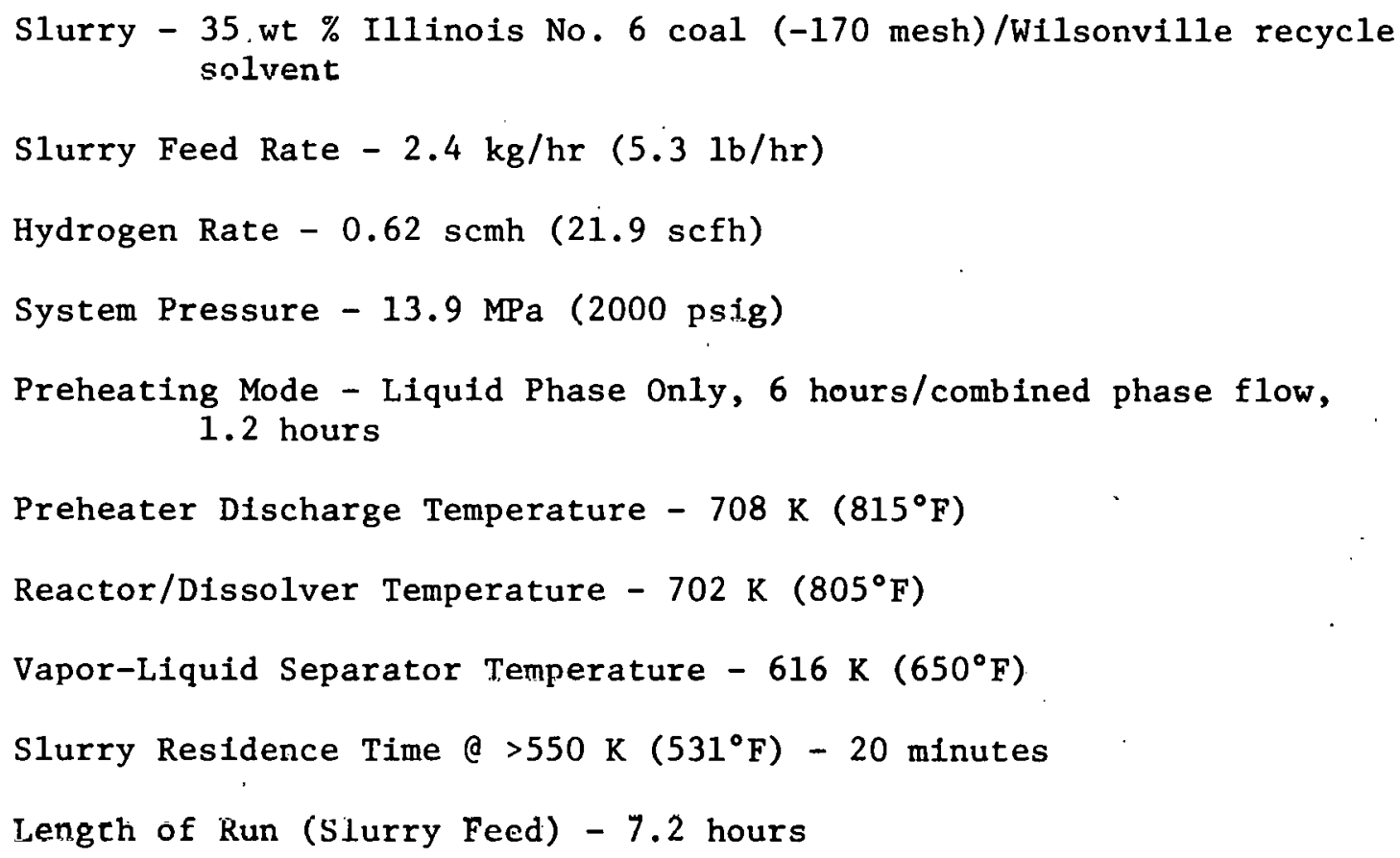


Table 2.2. Product slurry samples, run 7-29-79

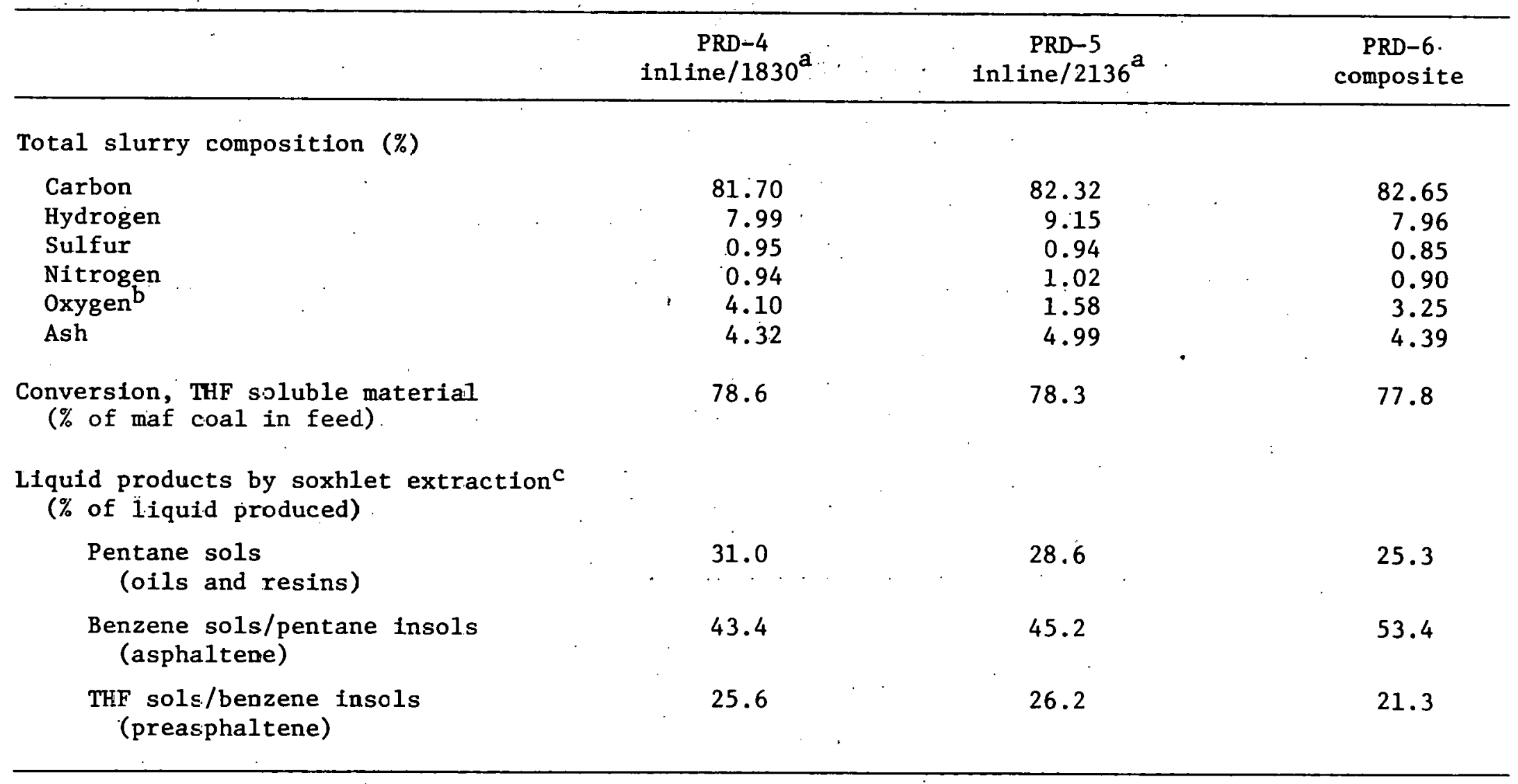

a Time of sample, slurry feed initiated @ $16: 5$ hours.

$b_{\text {By difference. }}$

${ }^{\mathrm{c}}$ Solids free liquid product minus recycle solvent in feed slurry

(assumes no change in recycle solvent during slurry liquefaction). 


\subsubsection{Work forecast}

Operator training sessions will continue.

\subsection{Coal Slurry Preheaters}

J. R. Thurgood and E. L. Youngblood

This preheater project is principally concerned with thermal and rheological characterizations of slurry flow in preheaters at preheating conditions (pressures up to $31 \mathrm{MPa}$ and temperatures to $810 \mathrm{~K}$ ). Experiments are made in conjunction with a companion project, Physical Properties of Coal Liquids. Installation of computer interface equipment for data logging and analysis is discussed in this section.

\subsubsection{Work accomplished}

Computer interfacing equipment was installed for pipeline viscometer rheological characterization data logging. BCD output from the feed tank digital load cell indicator transmits slurry feed tank weight to the computer and a pressure-to-current converter is used to transmit the pipeline viscometer differential pressure transmitter's pneumatic output signal. With this information the computer will generate a flow curve immediately after a data set is completed. Pipeline viscometer inlet and outlet temperatures, key preheater surface temperatures, and preheater electrical heat input are also continuously logged by the computer.

\subsubsection{Work forecast}

Two camples of H-coal PDU reactor effluent slurry have been received from Hydrocarbons Research Incorporated. Rheological characterization and density measurements will be made on this material during the first quarter of FY 1980.

\subsection{New Liquefaction Technology}

J. W. Larsen*, T. I. Sams, and B. R. Rodgers

Our working hypothesis has been that the ability of phenn t th give up its hydroxyl hydrogen readily in radical reactions and its inability to do much other radical chemistry than regain that hydroxyl hydrogen is central to its ability to aid the internal shuffle of hydrogen in coal. The hypothesized sequence of reactions is

$$
\begin{aligned}
& \text { coal }- \text { coal } \stackrel{\text { heat }}{\longrightarrow} 2 \text { coal } \therefore \\
& \text { coal }+\phi \mathrm{OH} \longrightarrow \operatorname{coal}-\mathrm{H}+\phi O . \\
& \phi O+\operatorname{coal}-\mathrm{H} \longrightarrow \operatorname{coal}+\phi \mathrm{OH}
\end{aligned}
$$


of course phenol interacts (solvates) strongly with coals. This also must play a role in the observed chemistry. In order to evaluate the importance of the hydroxyl hydrogen we have studied the pyrolysis of coal in diphenyl ether; which has all the functionality and character of phenol without the hydroxyl hydrogen, whose critical importance we had postulated. If the role of the hydroxyl hydrogen is dominant, then observed conversions with diphenyl ether should be much less than those obtained with.phenol. The data are shown in Table 2.3. It can be seen that the conversions obtained with diphenyl ether are much lower than those obtained with phenol. This supports the notion that phenol serves as a hydrogen carrier via its hydroxyl hydrogen.

Table 2.3. Conversions to pyridine solubles obtained with phenol and diphenyl ether

\begin{tabular}{lcccc}
\hline $\begin{array}{c}\text { Coal } \\
(\text { wt g) }\end{array}$ & $\begin{array}{c}\text { Solvent } \\
(\text { wt g) }\end{array}$ & $\begin{array}{c}\text { Run } \\
\text { temperature } \\
\left({ }^{\circ} \mathrm{C}\right)\end{array}$ & $\begin{array}{c}\text { Run } \\
\text { time } \\
(\text { min) }\end{array}$ & $\begin{array}{c}\text { Conversion to } \\
\text { pyridine soluble } \\
(\%)\end{array}$ \\
\hline Wyodak & none & ambient & none & 14 \\
Wyodak & none & 460 & 10 & 15 \\
Wyodak & $\phi \mathrm{OH}$ & 460 & 15 & 69 \\
Wyodak & $\phi \mathrm{O} \phi$ & 460 & 15 & 36 \\
Bruceton & none & ambient & none & 22 \\
Bruceton & $\phi \mathrm{OH}$ & 482 & 15 & 82 \\
Bruceton & $\phi 0 \phi$ & 482 & 15 & 46 \\
\hline
\end{tabular}

The conversions obtained with diphenyl ether are still greater than those obtained when dry coal is heated. Neave ${ }^{2}$ has suggested that the chloroform soluble fraction of coal is responsible for hydrogen donation and/or hydrogen transfer when coals are heated in media which are good solvents but poor hydrogen donors or transfer agents. Removal of the chloroform soluble fraction from coking coals retards or destroys their ability to coke and Neavel suggests that the same fundamental bond cleavages are responsible for the coking or the solubilization of coals. In the former case, continued heating leads to further cross linking as the radicals react with coal; in the latter, the radicals react with the hydrogen donors or transfer agents leading to permanent bond breaking and solubilization. If this model is correct, and it is very attractive, hydrogen transfer agents within the coal are responsible for the conversion observed with diphenylether. This can be tested by repeating these 
reactions using chloroform-extracted coals. If Neavel is correct, decreased conversion will be observed. Those experiments have been scheduled.

Unfortunately for the above argument, Franz has shown that a slow exchange between 1, 1-di-deuterotetralin and the ring hydrogens of phenol does occur under our reaction contitions. 3 Thus it is possible that diphenylether may have some hydrogen transfer ability, although it should be slight.

\subsection{In-Plant Environmental Monitors \\ D. D. Schuresko}

Fabrication of the field testing units continued during August. The electronics modules are being assembled and should be ready by october 1. These units will incorporate some final design changes, such as relocating the mercury arc lamp ignition pulse transformer from the electronics module to the optics unit. Thus the problem of lamp supply cables which can handle 6 amps of steady current and are insulated to 5 kilovolts is resolved by the use of two pairs of separate current supply and ignition pulse lines. This modification will make the umbilical bundle significantly smaller and more flexible and is a step in the direction of making the spotter explosion proof.

Additional Laboratory measurements were carried out with the prototype portable unit to provide performance data for presentation at the 1979 Symposium on Instrumentation and Control for Fnssil Energy Processes held in Denver, Colorado on August 20-22. The dynamic range of the spotters response exceeds the 0.1-10 $\mu \mathrm{gm}$ range of the data shown in Figure 2.1. The samples used were dilute solutions of perylene in cyclohexane which were placed $50 \mathrm{~cm}$ in front of the spotter. Figure 2.2 shows a plot of the distance dependance of the spotter output for conditions where the excitation beam is collimated and the telephoto lens aperture is stopped down to $7: 56$. The signal varles very nearly as (distance) $)^{-2}$ as expected.

\section{2.j References}

1. R. K. Traeger, R. M. Curlee, Preheater Studies in Coal Liquefaction, April 1 - June 30, 1978, SAND-78-1872 (Oct. 1978).

2. R. C. Neave1, Proceedings of the Coal Agglomeration and Conversion Symposium, Morgantown, West Virginia (April 1976).

3. J. A. Franz, Fue1, 58, 405 (1979). 


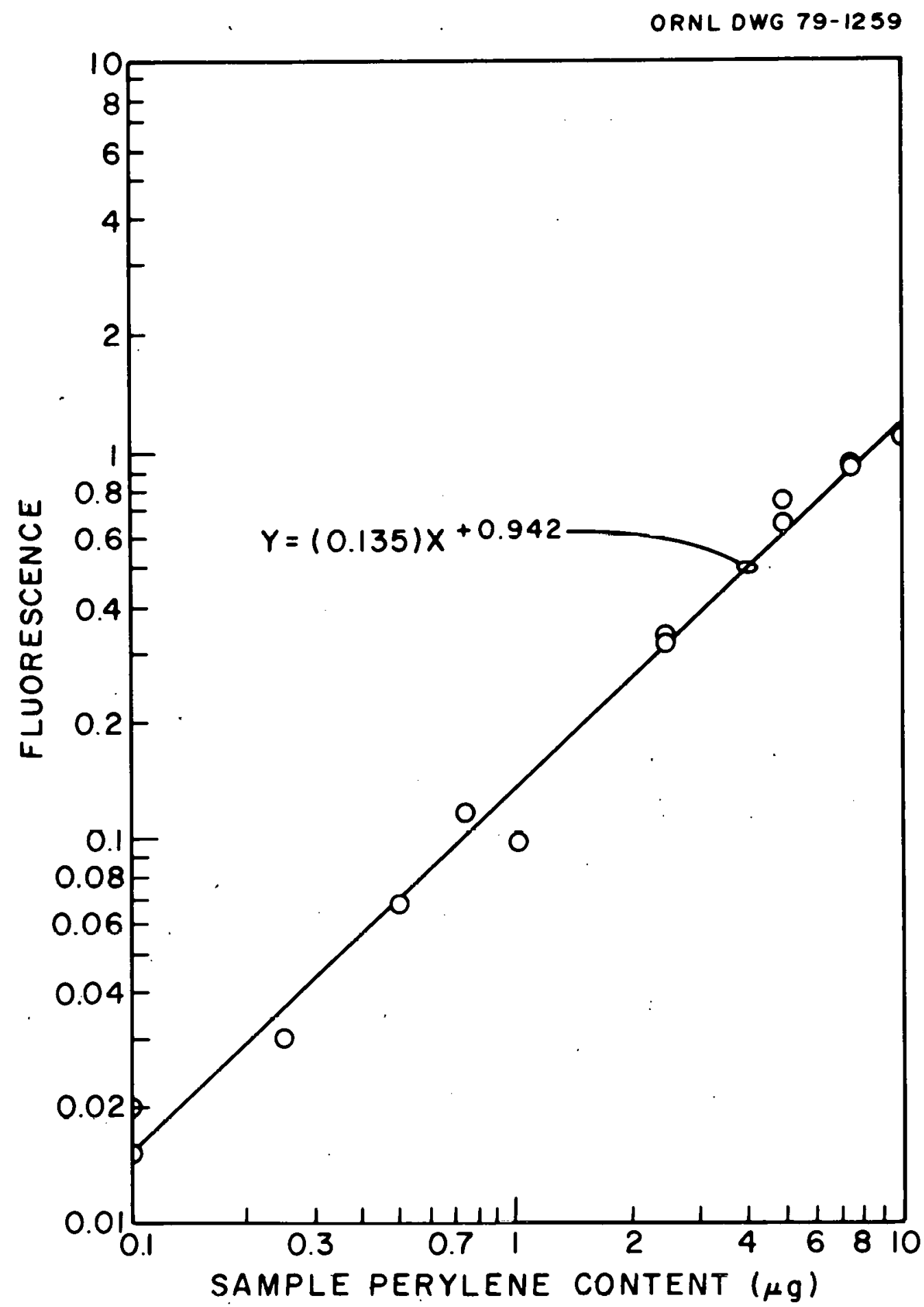

Fig. 2.1. Spotter output vs sample PNA content. 


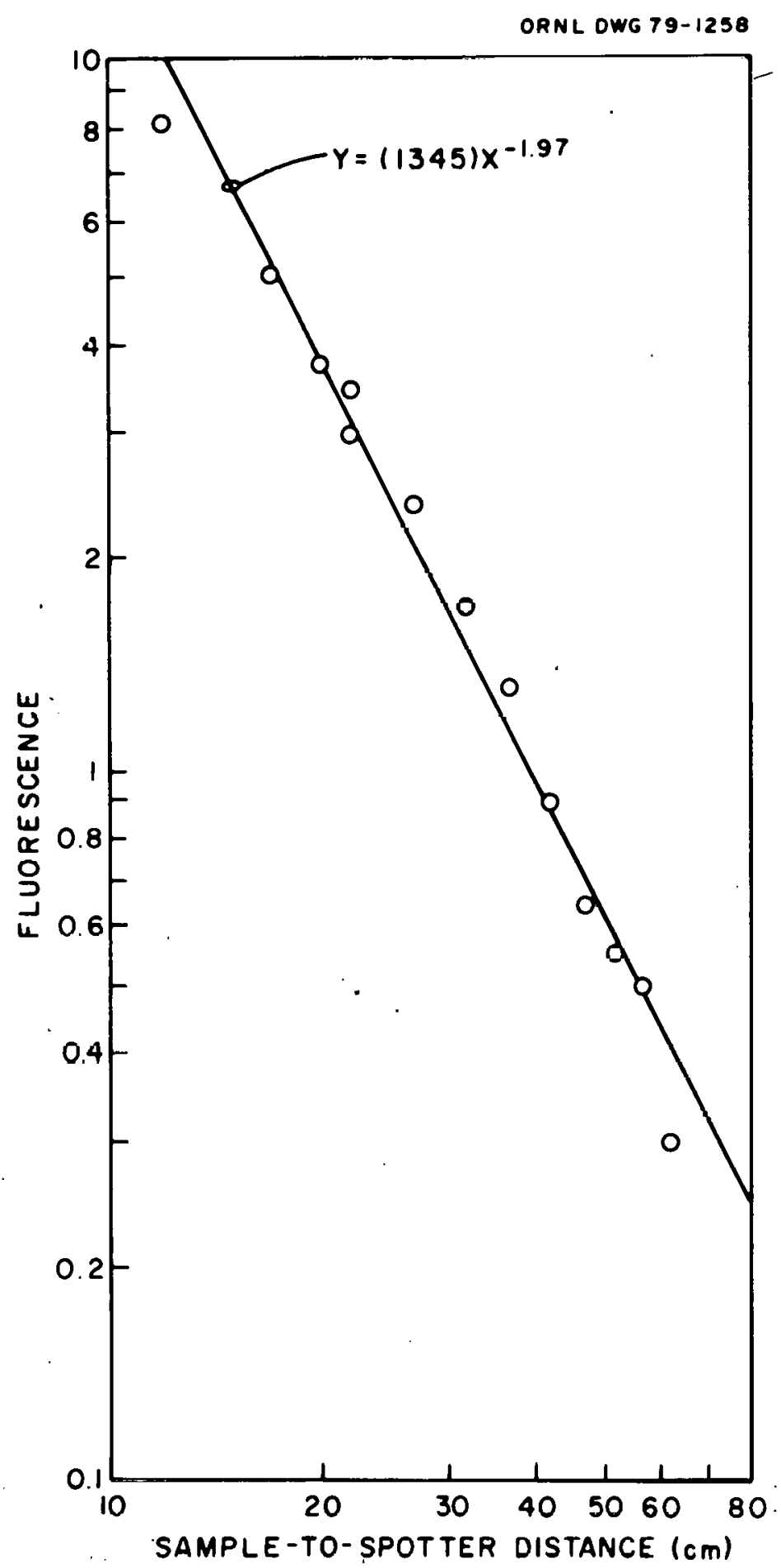

Fig. 2.2. Distance variation of spotter output. 


\section{CHEMICAL RESEARCH AND DEVELOPMENT}

\section{L. Poutsma}

\subsection{Chemistry and Structure of Coal}

M. L. Poutsma and M. Sahler*

Last month we presented a preliminary reaction scheme for the gasphase thermolysis of bibenzy 1 in the presence of $\alpha$-naphthol. Data for several more runs at lower conversion level have been gathered. However, the key observation this month concerns the role of $1,1^{\prime}$-binaphthalene4,4'-diol (1), from which we deduce that the scheme presented is seriously incomplete. Three lines of evidence point to this conclusion:

(1) Production of authentic $\alpha$-naphthoxy radicals by oxidation of $\alpha$-naphthol with $\mathrm{FeCl}_{3}$ at $100^{\circ} \mathrm{C}$ is well known to produce $\underline{\underline{1}}$ as the major product with minor amounts of 2,2'-binaphthalene-1,1'-diol (2). We have confirmed this behavior and isolated a pure sample of 1 . We can detect $\underline{1}$ with our glpc procedures but only after silylation. Analysis of silylated co-thermolysis products suggests that 1 was not present in significant quantities. However, when a small portion of 1 was added to bibenzyl- $\alpha$-naphthol before thermolysis, it could still be $\overline{\bar{d}}$ etected after reaction and silylation. Hence we conclude that significant amounts of 1 are not formed during the co-thermolysis itself. Yet the major co-thermolyis product derived from $\alpha$-naphthol is dinaphtho[1,2-b;2',1'-d]furan (3), which would appear to arise by dehydration of initially formed diol 2. Clearly then we cannot rationalize our results simply by coupling of $\alpha$-naphthoxy radicals, if they behave at $400^{\circ} \mathrm{C}$ in the gas phase in the same fashion as at $100^{\circ} \mathrm{C}$ in aqueous solution.

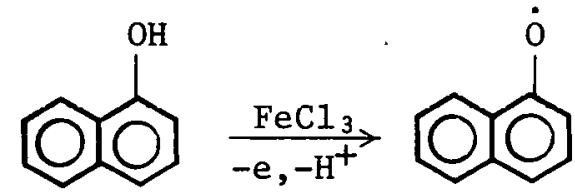

2<smiles>[O-]c1cccc2ccccc12</smiles>

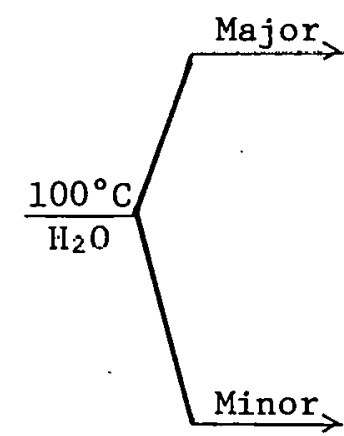<smiles>Oc1ccc(-c2ccc(O)c3ccccc23)c2ccccc12</smiles><smiles>OCCCc1ccc2c(O)c(-c3ccc4ccccc4c3O)ccc2c1</smiles>
$\underline{2}$<smiles>c1ccc2c(c1)ccc1c3ccccc3oc21</smiles>

*ORAU Summer Rcecarch Participant. 
(2) During co-thermolysis with an $\alpha$-naphthol:bibenzy1. ratio of 6.3 , the molar ratio of 3 :toluene produced was 5 whereas the maximum ratio is on $1 \mathrm{y} 0.5$ if $\underline{3}$ is prōduced from $\alpha$-naphthoxy radicals which in turn are formed by hydrogen abstraction from $\alpha$-naphthol by benzyl radicals.

(3) Thermolysis of $\alpha$-naphthol alone at $400^{\circ} \mathrm{C}$ produced detectable amounts of $\stackrel{3}{=}$.

Clearly the mode of genesis of $\underline{3}$ and its relationship to the thermolysis of bibenzyl must be more comp $\overline{\bar{p}}$ lex than we anticipated. Hence we will not report in detail the thermolysis results gathered this month because their interpretation demands clarification of this problem first:

\subsection{In-Process Tracer Studies of \\ Coal Liquefaction Chemistry}

M. L. Poutsma and C. J. Collins

The final analysis and assay of the $1-^{14} \mathrm{C}$-tetralin synthesized showed it to have a radiochemical purity of $96.6 \%$. It will be transmitted to the Chemical Technology Division for the in-process tracer run. 


\title{
4. MATERIALS ENGINEERING
}

\author{
R. A. Bradley
}

The materials engineering and associated technology reported here are in support of activities directed or coordinated by the Materials Section, Division of Planning and Systems Engineering, Fossil Energy. Other related work funded by the Division of Fossil Fuel Utilization and the Division of Fossil Fuel Processing is also included.

\subsection{Pressure Vessel and Piping Materials}

W. J. Stelzman, R. O. Williams, and D. $\Lambda$. Canonico

The program is concerned with the influence of an operating environment on the in-service reliability and safety of large pressure vessels for use in second generation coal conversion systems. The candidate steels from which these vessels will be constructed are subject to an environmentallyinduced embrittlement at the currently projected operating condition of these units. Of prime concern is the effect of the coal conversion environment, in particular hydrogen, on both low temperature and high temperature properties of these steels.

A draft of the documentation report for our multicomponent thermodynamic program has been turned in for typing.

We are nearing the end of a 400-h run in which ten samples of different histories have been exposed to hydrogen at approximately 1500 psi and $490^{\circ} \mathrm{C}$. The run has been without incident except that we have been bothered by loosing the signals from some of our strain gages late in the run. Hopefully, we will be able to locate the origin of this problem when the run is completed.

\subsection{Fossil Energy Welding and Cladding Development}

J. F. King and G. M. Goodwin

A proposal package for contract work by Sandvik has been prepared and is currently in the Purchasing Division. This contract will produce strip clad weld samples of various alloys, primarily type $320 \mathrm{Cb}$, on $21 / 4 \mathrm{Cr}-1$ Mo base material for our evaluation. This evaluation will include corrosion resistance, weldability; and mechanical properties of the clad deposit. 


\subsection{Fireside Corrosion of AFBC Heat Exchanger Materials}

T. G. Godfrey and J. H. DeVan

Examination of the samples from the 4500-h test at Fluidyne has been delayed due to the press of other commitments.

Preliminary metallographic examination of the EPRI specimens from the first 1000-h test at BCURA Leatherhead is reported in Chapter 11 of this report under TVA activities.

At the direction of DOE/ORO and METC we are preparing the experimental work plan for the proposed Boiler Materials Test Apparatus (BMTA) facility. The appruach adoped is to tirst determine the boundaries of safe operating conditions through a series of parametric studies of short duration ( $200 \mathrm{~h})$. The primary variable for the early tests will be excess air and the secondary variables will be those that affect mixing within the bed, such as primary/ secondary air, size consist, and superficial velocity. Results from these early tests will gulde selection of a set of "safe" operating conditions for one of the four AFBC units for a long-term test $(210,000 \mathrm{~h})$. The other three units will also be transitioned to longer term test as the parametric tests are completed.

We also provided cost estimates to METC for the instrumentation, metallography, and chemistry required for test interpretation and specimen analysis during BMTA operation.

\subsection{Failure Prevention and Analysis}

R. W. Swindeman

Plans have been made for ORNL staff members to visit the Fort Lewis SRC II plant in September. On site metallographic evaluation will be performed on the wash solvent column and future failure analysis activities will be formulated. Personnel from Battelle Columbus Laboratories visited ORNL, on August 7 and were briefed on failure analysis and surveillence work.

\subsubsection{Examination of corrosion coupons from SRC plants - (V. B. Baylor and J. R. Keiser)}

Chemical analysis of scale on corroded trays removed from the T105 fractionation Tower at the Wilsonville SRC plant confirmed that the deposit is primarily nickel sulfide.

A search was initiated of the literature concerning corrosive attack due to the following agents: ammonium chloride, naphthenic acid, and polythionic acid. 


\subsubsection{Examination of Johnson Screen Distributor Plate From METC 8-in. AFBC (T. G. Godfrey and M. D. Allen)}

The afr distributor plate from one of the 8-in. AFBC experimental units at the Morgantown Energy Technology Center (METC) developed a hole during a bed ignition sequence. At the time failure was detected, the bed of fresh limestone and Arkwright bituminous coal was being raised to $1550^{\circ} \mathrm{F}$ by underbed (plenum) propane-air injection. The operators surmised that the flame front propogated into the plenum space and created a torch directed at the underside of the distributor plate.

The Johnson Screen is constructed as a series of crossed, tapered bars held in a heavy ring. The screen is reported to be of type 304 stainless steel. The failure appears as an upward, flared hole, slightly off-center, with a thick crust of black, porous, clinker-like material.

Metallographic examination of sections from the distorted portion of the screen revealed a cored microstructure, systematic of a melted and heavily oxidized metal. Electron microprobe examinations of these areas showed only. $\mathrm{Fe}, \mathrm{Cr}$, and $\mathrm{Ni}$ with occasional embedded particles contaning $\mathrm{Ca}$. Sulfur was not detected in these sections. X-ray diffraction of the clinkerlike material showed iron oxides as the major phase.

The analyses indicate that the failure of the Johnson Screen was caused by excessive temperature and severe oxidation which resulted in localized melting. Chemical examination of the failed area guggests that the limestone and coal played no part in the failure. This indicates that propane ignition did occur in the plenum and produced the requisite high temperature.

\subsection{Materials for ZnC.1.2 Tiquefaction Process \\ V. B. Baylor and J. R. Keiser}

Assembly of the testing apparatus is almost complete with some minor amounts of electrical work yet to be done. Determination of thermal gradients in the loop has been initiated. Coated specimens were received from LockheedPalo Alto to be tested and approximately 20 other materials were machined into specimens, Specimens were measured, weighed, and identified.

\subsection{Materials to Resist Stress-Corrosion Cracking in Coa1 Liquefaction Pilot Plants}

V. B. Baylor and J. R. Kelser

Stress corrosion cracking U-bend specimens are still in place in both the Wilsonville and Fort Lewis SRC plants. Personnel responsible for materials testing at $\mathrm{H}$-Coal have requested $\mathrm{U}$-bend samples for their program. 
Assembly of laboratory equipment is almost complete and laboratory testing should begin next month.

\subsection{Development of Advanced $9 \mathrm{Cr}-1$ Mo Structural Steel}

V. K. Sikka

Mechanical property characterization, fabrication, weldability, and steam corrosion studies continued on experimental heats and one of the four DOE Reactor Research and Technology Division commercial argon-oxygencarburization (AOD) process heats. Several accomplishments made during the last month are as follows:

1. Three creep tests were completcd on weldment IC-9 (fillei wilt male from Quaker heat and PWHT at $732^{\circ} \mathrm{C}$ for $1 \mathrm{~h}$ ) and one on PC-10 (filler wire made from standard $9 \mathrm{Cr}-1$ Mo steel and PWHT at $732^{\circ} \mathrm{C}$ for $1 \mathrm{~h}$ ). All the creep data on PC-9, PC-10 and the previous weldments were compared with the base metal data. Results show that the weldments are generally weaker than the base metal and have low reduction of areas. Furthermore, the rupture times are independent of the filler wire composition and the PWHT. These observations 1mply that, when the weldments are tested, properties are controlled by a narrow heat affected zone (HAZ) which is tempered at a fairly high temperature during welding.

Attempts will be made during the next few weeks to either avoid or minimize such a $\mathrm{HAZ}$.

2. Eighteen experimental heats were melted and fabricated into 13-mm thick plates. These heats have nominal composition with variations of $\mathrm{Si}, \mathrm{N}$, and $V$. Three creep tests on heats containing $0.13,0.36$, and $0.46 \% 3 i$ were conipleted during the last months. Three additional tests on these heats are currently 1n' progress. Charpy-impact tests and additional creep tests on these heats are planned for the next few months. Data on these heats will be used in writing the ASTM Specifications for the alloy.

3. Recent note from Carpenter Technology indicated that the two 15-ton heats will be melted during the first week of September. Test coupons from these heats are expected at ORNL by the first week of nctober.

4. Welght gain data on spectmens of several chromium-molybdenum steels during $2556 \mathrm{~h}$ test in superheated steam were obtained. The chromium content for these heats varied from $5-9 \%$ and the $S i$ content varied from $0.01-0.36 \%$. The weight gains were approximately the same for 5-9 $\mathrm{Cr}$ heats of the same silicon level, indicating thereby that $\mathrm{Cr}$ has only a small influence in 1mproving steam corrosion resistance. For the 9-Cr heats, an increase in Si content from $0.01-0.36 \%$ decreased the weight gain to half of what was observed for a $\mathrm{Si}$ level of $0.01 \%$. These results, therefore, suggest that the Si content has a very strong effect on the corrosion resistance of $\mathrm{Cr}-\mathrm{Mo}$ steels and thus it should be carefully optimized. 


\subsection{Ceramic Recuperator (Heat Exchangers) \\ V. J. Tennery, G. C. Wei, and G. W. Brassell}

In Subtask A, entitled "Economic Application, Design Analyses, and Materials Avallability for Ceramic Heat Exchangers," work has continued on report preparation summarizing results of the three subcontracts completed this fiscal year. Results of the Garrett-AiResearch contract indicate that ceramic tube and shell heat exchangers capable of heating $9000 \mathrm{~kg}(20,000 \mathrm{1b})$ to $11,400 \mathrm{~kg}(25,000 \mathrm{lb})$ of air per hour from $38^{\circ} \mathrm{C}$ $\left(100^{\circ} \mathrm{F}\right)$ to $985^{\circ} \mathrm{C}\left(1800^{\circ} \mathrm{F}\right)$ can have simple payback periods of approximately 1.5 years when used as recuperators on fossil fired furnaces based upon fossil fuel costs of approximately $\$ 3,35$ per $10^{6}$ BTU. Heat exchangers with economies and capable of heat transfer rates of approximately $90 \times 10^{6} \mathrm{BTU} / \mathrm{h}$ appear achievable if ceramic tube costs can approach $\$ 2.25$ per $\mathrm{kg}$ ( $\$ 9$ per $1 \mathrm{~b}$ ). A survey of four ceramic industry vendors indicated confidence that such material costs were achievable in the next five years if an adequate development and commercialization program is started relatively soon.

In Subtask B, entitled "Testing and Evaluation of Candidate Ceramic Heat Exchanger Elements," two major efforts continued essentially on schedule.

Assembly and instrumentation of the Ceramic Recuperator Analysis Facility (CRAF) continued. Repair of the Refractory Test Facility (RTF) which is the combustor for the CRAF has been completed. This repair included installation of new burner blocks, fabrication of a new refractorylined door, and repair of the door frame with ramming refractory mix and the spalled lining with fibrous insulation. The purchase order of a sufficient quantity of high-vanadium No, 6 fuel o1l for the $500 \mathrm{~h}$ CRAF Test No. 1 was placed this month. We plan to start the CRAF Test No. 1 using this No. 6 fuel ofl on September 10.

This month we recelved several SiC tubes including Refel SiC (Pure Carbon Co.), sintered a-SiC (Carborundum Co.), and CVD SiC and CVD SiC coated on SiC (Deposit and Composite). To date, we have received all the ceramic tubes for CRAF Test No. I except the CVD SiC tubes made by Materials Technology Corp. The newly promised dates of delivery from the vendors of a high-temperature suction pyrometer for flue gas temperature measurement and Pitot tubes for combustion air flow rate measurement are mid-September.

Pretest characterization of the ceramic tubes to be tested in CRAF Test No. 1 continued. Metallography and electron microprobe analyses are essentially completed. Chemical $x$-ray diffraction, and SEM analyses are in progress. The permeability apparatus modified for measurements on highpermeability tubes was completed and measurements started. A high-temperature dilatometer was repaired this month. It will be used for measuring the thermal expansion coefficient of the ceramic tubes. 
A meeting was held at Hague International in South Portland, Maine, by V. J. Tennery and G. W. Brassell to review the status of the work plans for the 200-h pressurized ceramic heat exchange test using coal-oil-mixture (COM) fuel. Frabrication of the six finned tubes having $\alpha-S i C$ seal seats is complete and permeability tests are finished. Plans are to start the $200 \mathrm{~h}$ flring test on September 24.

Inquiries were received this month from two industrial firms who are doing marketing analyses for ceramic heat exchangers, and information developed in this program and appropriate to their needs was provided. 


\section{COMPONENT AND PROCESS EVALUATION STUDIES}

J. M. Holmes and J. E. Jones Jr.

Component and Process Evaluation Studies in progress in the Engineering Technology Division Fossil Energy Program include the following.

- Coal Feeder Test Program

- Survey of Industrial Capability for Coal Handling Equipment

- Slurry Test Loop

P. K. Carlson attended the Sixth Annual Conference on Coal Gasification, Liquefaction, and Conversion to Electricity in Pittsburgh, PA, froni July 31 through August 2.

\subsection{Coal Feeder Test Program \\ B. T. Thompson}

Work on this program is being held up for the present.

\subsection{Survey of Industrial Capability for Coal Handling Equipment \\ F. C. Zapp, O. W. Thomas, M. D. Silverman, and D. A. Dyslin}

The survey report has been edited and typed in final form and is in the process of final proofreading.

\subsection{Slurry Test Loop}

P. K. Carlson and L. F. Parsly

On August 27, a shakedown run of the Slurry Test Loop was successfully completed. The Moyno pump was run with water for approximately two hours to demonstrate operability and flush dirt and rust from the system. High pressure operation is planned.

$$
5.4 \text { SRC I., SRC TT, and H-C.na.T. }
$$

SRC and H-Coal work being done in the Engineering Technology Division is reported in Section 13 . 
6. ENGINEERING STUDIES AND TECHNICAL SUPPORT

R. W. Glass

Engineering studies and technical support are provided primarily for the DOE/FE Division of Fossil Fuel Processing. The effort includes: the development of analytical tools for use in the evaluation of processes and equipment; the technical and economic evaluation and comparison of coal conversion processes and subprocesses on a unfform basis; surveys of the need for coal conversion equipment and the capability of industry to provide such equipment; and studies of the magnitude and control of coal conversion plant emissions.

\subsection{Process Modeling}

R. Salmon, D. M. Lister, O. L. Culberson, D. G. Ball, and K. W. Childs

\subsubsection{Contract Objective}

The objective is to assist DOE/FE in its plan for computer analysis and computer support for coal conversion studies. This includes assistance to Purdue and Lehigh Unfversities in the development of computer programs for this plan. Physical property data are being collected and computerized primarily by Purdue and will be used in support of programs prepared by both universities. Purdue's general design program will aim at material and energy balances, equipment size and costing, plant capacity, and general economics. Lehigh's dynamic simulation programs will address plant design primarily from the standpoint of process performance during transient operations, but can also be used for steady-state conditions. A single flowsheet will be selected to assess the operability and complementary utility of both design programs.

\subsubsection{Status Summary}

\section{Checkout of Lehigh Models}

Checkout of the single prectsion results obtained from running the Lehigh Models continued. The following paragraphs summarize the findings.

a. Compressor Mode1 (COMP1) - fond apreement with the CDC reaulto was obtained for the Time (hrs.), Speed (RPH), and Temperature (R) variables. Unfortunately, the values of Steam $(1 \mathrm{~b} / \mathrm{hr})$ obtained were not as good, the worst errors being of the order of $4 \%$.

b. Carbon Dioxide Removal (DCO2) - Subroutine ZBENTY required by the model has not been supplied. 
c. Dynamic Hydrogen Plant version 2 (DHP2) - Good agreement with the CDC results was obtained.

d. Gasifier Model - Subroutine ZSYSTM required by the mode1 has not been supplied.

e. Methanation Plant Version 1 (METH1) - Good agreement with the CDC results was obtained.

f. Physical Properties Package (PHYSP) - Good agreement with the CDC results was obtained.

g. Steady State Hydrogen Plant Version 1 (SSHPI) - Good agreement with the CDC results was obtained.

Conversion to Double Prectsion

The compllations of the double precision versions of the models showed that many common areas contained misaligned double precision variables. Thus, the extremely laborious and tedious task of reordering these commons was undertaken and is almost complete.

Documentation of Double Precision Converter Program

This task was resumed. Detalled formal flowcharts of all subroutines have been completed. During this process two minor errors were detected and corrected. It was also realized that subroutine SEARCH would not perform as required under certain circumstances and, thus, it was recoded.

\subsection{Coal Liquefaction Advanced Research Digest}

F. M. O'Hara, Jr., and R. W. Glass

\subsubsection{Contract Objective}

The objective is to provide continuing technical assistance to DOE/FE by preparing digest reviews of current or potential subjects relating to coal conversion technology.

\subsubsection{Status Summary}

A first draft of the article "Chemical Reaction Mechanisms of Coal Liquefaction" for the third Digest issue was completed and submitted for review this month. Rewriting of the draft will begin in early October following recelpt of reviewer, comments. The internal review of "Depolymerization of Coal" which was inttlated last month has been completed and the article is being revised to incorporate reviewer suggestions. 


\subsection{Survey of Industrial Coal Conversion Equipment Capabilities}

W. R. WIIllams and D. W. Hatcher

\subsubsection{Contract Objective}

The objective of this project is to conduct surveys of industrial equipment capabilities that will identify the present capability of industry to supply the equipment needed. The project will also determine research and development needs, including lead time requirements, for producing equipment of advanced design for the various unit operations of critical importance to the Division of Fossil Fuel Processing.

\subsubsection{Status Summary}

The last three reports related to the survey of industrial coal conversion equipment capabilities are being edited by Technical Publications. 'lhese include a report on letdown valves (ORNL/TM-6585), a report on equipment operating experience, prices, and development programs (ORNL/TM-6587), and a report providing an executive sumnary of all work done on survey of industrial coal conversion equipment capabilities (ORNL/TM-6810).

\subsection{Environmental Controls for Low-Btu Gasification}

S. P. N. Singh, M. S. Edwards, J. F. Fisher, G. R. Peterson, and R. Salmon

\subsubsection{Contract Objective}

The objective of this project is to evaluate the various environmental control processes that might be used in connection with low-Btu gasification facilities and to determine the economic tradeoffs for various processes and levels of control.

The project is divided into two phases: Phase I consists of Tasks 1 through 5 of the work statement and covers the preparation of a detailed work plan and the selection of gasification and environmental control processes for use in the study. Phase II consists of Tasks 6 through 8 in the work statement and covers the collection and analysis of technical and economic data on the various environmental control processes and the preparation and analysis of flowsheets showing overall systems of environmental control processes used with various gasifiers. 
6.4.2. Status Summary

DOE/Fossil Energy approval on the two draft reports titled Costs of Environmental Control Processes for Low-Btu Coal Gasification Plants (ORNL-5425) and Evaluation of Elght Environmental Control Systems for Low-Btu Coal Gasification Plants (ORNL-5481) has been recelved.

Proponent review of both reports was completed in June, followed by incorporation of reviewer comments and suggestions in early July. It was expected that editing, publication, and distribution could be completed by late August, but delays have forced a revision of the anticipated distribution date to December 1979. 


\title{
7. PROCESS AND PROGRAM ANALYSIS
}

\author{
R. W. Glass
}

Process and program analysis studies are being conducted for the DOE Fossil Energy Engineering Economics and Standards Section of the Planning and Systems Engineering Division. This effort includes research studies on most of the coal conversion and utilization processes. The program objective is to provide on a consistent basis, technical and economic evaluations of competing processes and systems for coal conversion and utilization.

\subsection{In Situ Coal Casification}

M. S. Edwards and W. C. Ulrich

\subsubsection{Contract Objective}

The objective of this program is to provide technical and economic evaluations of candidate processes for the conversion of coal in situ to fluld products presently of interest. During FY 1977, technical and economic evaluations of the linked vertical well process applied to subbicuminous coal were addressed. Three alternative end product configurations were considered - electricity, SNG, and syngas. In FY 1978, an evaluation was conducted of an in situ facility for producing gasoline from methanol via the Mobil-M process.

\section{1 .2 Status Summary}

The final report of our 1977 technical evaluation of in situ cual gaslfication, Process Vesigns and Economlc Evaluations for the Linked Vertical Well In Situ Coal Gastfication Process (ORNL-5341), was published and distributed on August 22. This report detailed three conceptual process designs and cost estimates which illustrated the following potential applications of underground coal gasification: (1) a 900-MW(e) combined-cycle electric generating plant fired by low Btu gas, (2) a subst1tute natural gas (SNG) plant producing 155 MMscfd of $954 \mathrm{Btu} / \mathrm{scf}$ gas, and (3) a synthesis gas plant producing 388 Malscfd of gas suitable for further conversion to chemicals.

Designs were based on experimental data and mathematical modele from the Laramie Energy Research Center on the linked vertical well (LVW) in situ coal gasification process. In-place coal consumption for the three facilities is 18,073, 22,951, and 22,951 tons/day, respectively, based on a subbituminous Wyoming coal. Respective capital investments were estimated to be $\$ 395, \$ 351$, and $\$ 312$ million in first-quartcr 1977 dollars. Product prices were calculated as a function of the debt/equity ratio, the annual earning rates on debt and equity, the cost of coal, and plant factor (onstream efficiency). Using a debt/equity ratio of $70 / 30$, an interest rate on debt of $9 \%$, an after-tax earning rate on 
equity of $15 \%$, a coal feed cost of $\$ 5 /$ ton, and a plant factor of $90 \%$, product prices were $19 \mathrm{mills} / \mathrm{kWh}$ for electricity, $\$ 2.89 / 10^{6}$ Btu for SNG, and $\$ 2.48 / 10^{6}$ Btu for syngas. Calculated overall thermal efficiencies for the three facilities were 24,38 , and $40 \%$, respectively, based on in-place coal.

Preparation of the 1978 report, Evaluation of an In Situ Coal Gasification Facility for Producing M-Gasoline via Methanol (ORNL-5439), is nearly complete, with publication expected in late September.

\subsection{HYGAS Modeling}

J. P. Meyer, G. C. Frazier, J, W. Wells, and J. P. Belk

\section{2:1 Contract Objective}

The objective of this project is to develop a computer model of the HYGAS gastfier.

\subsubsection{Status Summary}

The draft final report Mathematical Model of the HYGAS Pilot Plant Reactor (ORNL-5475) has been revlewed and approved for issue by DOE-FE/DPSE. Several copies have since been distributed for limited proponent review by IGT and others with final revisions scheduled near the end of the fiscal year. Publication and distribution are expected to be complete in December.

\subsection{High Btu Gas}

R. W. Glass

\subsubsection{Contract Objective}

This subprogram is being analyzed under subcontract by the Scientific Design Company, Incorporated (SD) with A. S. West as Project

Manager. The present work is divided into three phases as follows:

1. The objective of Phase I is to provide technical and economic evaluations of competing processes, concepts, and systems for the production of high Btu gas from coal.

2. The objective of Phase II 1 s to monitor and analyze data from the HYGAS Pllot Plant.

3. The objective of Phase III is to perform a technical and economic evaluation of the Battelle Agglomerating Ash Burner Process for the production of medium Btu fuel gas, synthesis gas, and hydrogen from coal. 


\subsubsection{Status Summary}

As mentioned in previous progress reports, Phase I activities in this project have resulted in the issue of a final report, Battelle Agglomerating Ash Burner Process for High-Btu Gas Applications (ORNL/Sub$7240 / 1$. Further evaluation of the Battelle process for medium-Btu gas applications (Phase III) has been completed and issue of the final report (ORNL/Sub-7240/4) occurred in July.

Monitoring of IGT's HYGAS Pilot Plant by SD engineers was discontinued during the month of July. Effort is currently directed toward preparation of a final report on this activity. This report is to provide a synopsts of operations observed and a discussion of problems assoclated with pilot plant operations, their causes, and probable solutions. A consultant, Fred A. Zenz, is assessing two major problems about which SD and IGT have differing viewpoints. A draft of the final report is expected to be completed in September.

\subsection{Direct Combustion}

E. C. Fox and T. D. Anderson

\subsubsection{Contract objectives}

The purpose of this study program is to assist DOE/FE in their effort to develop a national strategy to increase the near-term use of coal through direct combustion; the applications of Liteiest in this study are the small-to-moderate industrial user and the large residential/commercial user. The following objectives w1ll be accomplished.

1. Identify and quantify the important factors restricting the use of coal in the sectors of interest.

2. Evaluate potential technological and institutional solutions to the problems identified in (1) above.

3. Make recommendations to DOE/FE relative to the most promising approaches to Increasing the near-term use of coal.

\section{4 .2 Statue summary}

The main report "Conversion to Direct Coal Combustion in the Industrial and Commercial/Residential Sectors - A Study of the Barriers to Implementation in the Near Term,". ORNL/TM-6139, is being prepared for final publication. 


\subsection{Advanced Power Conversion Systems}

J. E. Jones Jr. and A. P. Fraas $a$

\subsubsection{Contract objective}

The objectives of this project are to review selected major advanced power conversion systems and to assess these systems with respect to their basic R\&D status.

\subsubsection{Status summary}

A total of eleven systems or components of systems were evaluated. Draft reports covering all of these topics, an overall summary report, and an executive summary report have been completed and are undergoing final review.

\subsection{Fue1-Grade Methanol Synthesis Technology Assessment}

R. Salmon, M. S. Edwards, and R. M. Wham

\subsubsection{Contract Objective}

The objective of this work is to review and assess the present state-of-the-art of indirect liquid fuels synthesis, with particular emphasis placed upon those processes which produce methanol suitable for use as fuel as the primary or principal product.

\subsubsection{S.tatus Summary}

Information was obtained on currently commercial methanol synthesis processes (ICI, Lurgi, Haldor-Topsoe, and Mitsubishi Gas-Chemical), previously commercial technologies and concepts, and developing processes (i.e., the Chem Systems three-phase reactor process and the Wentworth Brothers Methyl Fuel process). These processes were reviewed, a judgmental assessment of relative technical and economic potential of the identified processes, relative to production of fuel-grade methanol, was then performed, and a draft final report, Production of Methanol and Methanol-Related Fuels from Coal (ORNL-5564), was prepared. Initial DOE comments on the draft report have been received and several copies have since been made avallable for proponent review. Final revisions to the report began in August and technical editing is expected to begin in early October. Conclustons summarized from this study are:

1. We did not find any discarded or obsolete methanol synthesis processes that appear to offer any advantage over currently-commercial processes for the production of fuel-grade methanol. Thus, if the study is restricted to the production of fuels consisting essentially of

$a_{\text {Consultant }}$ 
methanol with minor amounts (up to $20 \%$ ) of other fuel-type compounds as impurities, then our conclusion is that no process is available that appears to be better than current methanol synthesis technology.

However, if the scope of the study is expanded to include the production of other synthesis products (for example, Fischer-Tropsch type products, olefins, etc.) and the possible conversion of such products to other fuels (such as gasoline or diesel fuel), then the possibilities for new process development are enormously increased. This appears to us to be a very fruitful field for process and catalyst research and development.

2. It appears that for the production of industrial methanol, the low-pressure process (50-100 atm) has a clear economic advantage over the older high-pressure process (200-300 atm).

3. The industrial preference for the low-pressure process since its introduction in about 1966 is not based on greater product purity or improved selectivity, but on better overall process economics. Thus it appears that even if the product purity specifications are relaxed to permit the production of fuel-grade methanol, the low-pressure process will still have the economic advantage.

4. The capital cost of the final product purification section is negligible in comparison to the costs of other parts of the plant. Operating costs for the final distillation towers are also negligible since the heat can be supplied by low pressure steam which will generally be avallable in excess quantities in a coal-to-methanol plant. Thus elimination of product purification in a fuel-grade methanol plant reduces costs by only a very minor amount.

5. Development of a synthesis catalyst of greater activity could substantially reduce the cost of methanol production. There is no indication at present that such a catalyst is close to discovery. However, there is no reason to rule out the possibility of such a development in the future.

6. The Mobil MTG (methanol to gasoline) process has shown the potentlalities of upgrading the initial synthesis products to highoctane gasoline. If similar upgrading processes could be developed for a wider range of initial synthesis products (for example, FischerTropsch products), then the possibilities for economic combinations of synthesis conditions, catalysts, and products are greatly increased. Industrial research in this area appears to be active.

7. In a coal-to-gasoline plant using the methanol-Mobil-MTG route, the capital investment in the methanol synthesis 1onp is only about $10 \%$ of the total facility cost. The largest part of the total investment is in the coal handling, gasification, oxygen plant, gas purification, and utilities (steam, power, and water) systems. 
8. New catalyst development could take place at any time which could result in more economical process routes to the production of methanol-related fuels from synthesis gas. This possibility is especially bellevable if the acceptable product spectrum is expanded to include higher alcohols, aliphatics, aromatics, ethers, and other compounds which wight be useful as automotive or turbine fuels. Also, new developments in methanol synthesis catalysts could increase the optimal operating pressure for large-scale fuel-grade methanol plants and could increase the maximum methanol throughput per train, thus improving the economics. Al1 these possibilities appear to be under active investigation by industry. However, because the contribution of the synthesis section to the overall product cost is already modest, major reductions in product cost are unlikely to result.

\subsection{Liquefaction Technology Assessment (LTAS)}

R. C. Forrester III, R. Salmon, A. R. Irvine, S. P. N. Singh, J. F. Fisher, R. M. Wham, and S. W. Thiel

\subsubsection{Contract Objective}

The objective of this study is to provide a comparative assessment of the technical feasibility, economic competitiveness, and environmental acceptability of selected coal liquefaction processes representing different process classes on a uniform, consistent, and impartial basis.

This assessment encompasses four phases of work, identified ao Phase 0, Phase I, Phase II, and Phase III. Each phase includes development of process designs, capital and operating cost estimates, process economic analysis, sensitivity studies, and assessment of technical feasibility and risk on as consistent a basis as possible. Existing process designs and cost estimates will be used whenever possible, with modification as necessary.

\section{7 .2 Status Summary}

Writing of the Phase 0 draft final report was completed on August 17 , followed by a preliminary in-house review. After minor modification, the draft report was transmitted to Frank M. Ferre11, DOE/DPSE, for review by members of the LTAS Steering Committee. Following receipt of DOE comments, the report will be made available for limited proponent review and final changes will be incorporated shortly thereafter. The publication process is expected to begin in late November.

Phase I activities have gotten underway during the month with the acceptance by Fluor Engineers and Constructors of a limited letter subcontract to begin work on the lindlrect liquefaction process designs. A "kickoff" meeting is scheduled to take place in Houston on September 4, when work schedules, scope detalls, and project management plans will be 
established. As mentioned previously, Phase I scope includes analysis of the EDS direct liquefaction process (Eastern bituminous coal) and an indirect liquefaction process: spectfically, Lurgi gasification of a Western subbituminous coal followed by synthesis of methanol. Three methanol product upgrading options will be examined:

1. Drying to turbine fuel use specifications,

2. Upgrading to gasoline blending specifications,

3. Conversion to gasoline via the Mobil-M process. 


\title{
8. FOSSIL ENERGY ENVIRONMENTAL PROJECT
}

\author{
C. R. Boston
}

The Fossil Energy Environmental Project provides DOE with program assistance in the performance of environmental assessment functions related to the expansion of fossil energy conversion technologies, performs assigned technical assistance tasks, and conducts programmatic environmental investigations that are critical to the early realization of advanced fossil energy technologies.

\subsection{Stored Solids Study} \\ W. J. Boegly, Jr., C. W. Francis, H. W. Wilson, Jr., E. C. Davis, \\ S. K. Hall, and S. Y. Lee
}

During the reporting period, column leaching studies were initiated on Grace/Ebasco/Texaco solid waste. Two types of watering regimes are being used. In the first type, water is applied in the usual manner of a single application of a set amount of deionized water in a 24-hour period. In the other column, the same volume of water is applied, but the flow rate of the incoming water is adjusted so that this application is continuous over the entire 24-hour period. This will enable a comparison of leachate quality when the residence time of the leaching. solution in the column is varied. Equal fractions of leachate are being collected using a mechanical fraction collector. The ability to collect equal fractions continuously will result in more accurate quantification of the dissolution rate of toxic elements from the waste. A constant fiow column also has the potential for experiments using an intermittent flow to the column to provide a wetting/drying cycle that can be both varied and exact.

Soil sampling trips to both the SRC-I and SRC-II demonstration plant sites have been ocheduled for mid-September to coincide with geohydrologic subcontractor's work at the SRC-II site.

Requests have been made to the industrial partners for the various DOE/FE demonstration projects requesting release of the ORNL leaching data on their solid waste for use in the preparation of environmental impact statements for their demonstration plants. To date, releases have been obtained for two of the solid wastes (Grace/Texaco Gasifier and British Gas Lurgi). It is anticipated that the remaining data will be releaced during the month of Scptcmber. 
A trip was made to the Waterways Experiment Station of the U. S. Corps of Engineers in Vicksburg, Mississippi to discuss leaching experiments on solid wastes. At the present time they have 22 lysimeters in operation (11 each 6-ft. diameter and 11 each 30-inch diameter units). These lysimeters are currently being used in studies that they are performing for EPA on the codisposal of municipal and industrial solid wastes. This installation appears to be the largest facility of this type in the United States.

\subsection{Processing of Coal Conversion Wastes for Disposal and Resource Recovery}

R. M. Canon, G. Jonee, Jr., and J. S. Watson

Three gasifier wastes have been subjected to direct leach with each of three acids: nitric, sulfuric, and hydrochloric. These experiments were performed with $6 \mathrm{~N}$ acid at reflux temperatures and an initial liquid to solid ratio of 10:1. Material balances were excellent for all tests, and the values shown for $\mathrm{Al}$ and $\mathrm{Fe}$ in Table 8.1 are accurate within $+3 \%$. On this basis alone, $\mathrm{HCl}$ would appear to be the acid of choice for all three ashes, giving recoveries at least equal to (and sometimes much better than) those for sulfuric acid. However, the cost of different acids and the potential availability of sulfuric acid from gasifier off-gas processing must also be considered. Nitric acid was the least efficient in all cases. The experiments with $\mathrm{H}_{2} \mathrm{SO}_{4}$ on GA2 demonstrate the improvement possible with long-term leaches. 4 Data for GA2 are not in agreement with previous data for the same residue (previous tests showed 1ittle recovery with $\mathrm{H}_{2} \mathrm{SO}_{4}$ ), and this may result from the use of solids from different batches of material. Early tests were performed on a small sample of material available at that time; more recently, a substantially larger quantity of homogeneous residue has become available.

All streams from these experiments are also being analyzed for trace metals using $x$-ray fluorescence and inductively coupled plasma techniques (ICP.). Additional tests with various acid concentrations, temperatures, and leach times are planned.

\subsection{Coal Conversion Demonstration Projects}

\subsubsection{Liquefaction projects - S. G. DeCicco}

This activity is reported in Chapter 13. 
Table 8.1. Metals Recovery from Gasification Ash by Acid Leaching

\begin{tabular}{|c|c|c|c|c|c|}
\hline \multirow[b]{2}{*}{ Ash } & \multirow[b]{2}{*}{ Acid } & \multirow{2}{*}{$\begin{array}{c}\text { Leach Time } \\
(\mathrm{hr})\end{array}$} & \multicolumn{2}{|c|}{$\%$ Recovery } & \multirow[b]{2}{*}{ Run No. } \\
\hline & & & & $\mathrm{Fe}$ & \\
\hline \multirow[t]{4}{*}{ GA2 } & $\mathrm{H}_{2} \mathrm{SO}_{4}$ & 16 & 86 & 81 & 005 \\
\hline & $\mathrm{H}_{2} \mathrm{SO}_{4}$ & 4 & 65 & 57 & 014 \\
\hline & $\mathrm{HNO}_{3}$ & 4 & 21 & 23 & 015 \\
\hline & $\mathrm{HCl}$ & 4 & 84 & 86 & 013 \\
\hline \multirow[t]{3}{*}{ GA3 } & $\mathrm{H}_{2} \mathrm{SO}_{4}$ & 4 & 89 & 77 & 017 \\
\hline & $\mathrm{HNO}_{3}$ & 4 & 71 & 61 & 020 \\
\hline & $\mathrm{HCl}$ & 4 & 83 & 78 & 019 \\
\hline \multirow[t]{3}{*}{ GA4 } & $\mathrm{H}_{2} \mathrm{SO}_{4}$ & 4 & 73 & 66 & 023 \\
\hline & $\mathrm{HNO}_{3}$ & 4 & .63 & 62 & 028 \\
\hline & $\mathrm{HCl}$ & 4 & 72 & 94 & 029 \\
\hline
\end{tabular}




\subsubsection{Gasification projects - A. J. Witten}

MT.GW - The ER is due September 14. Thus far, we have received, in draft form, all of Chapter 3, Environmental Setting, along with the Site Evaluation and Selection Report which will become the Alternative Sites Section of the ER. The initiation of PDEIS preparation is scheduled for September 14, based upon receipt of the complete ER, with a PDEIS completion date of December 14. We can, at this time, begin PDEIS preparation and substantial work can commence when we receive ER Chapter 2, Description of the Proposed Action. DOE and MLGW were made aware of this at the Monthly Review Meeting at Foster Wheeler on August 23. An effort will be made by Foster Wheeler to provide us with a preliminary draft of this chapter.

A tentative meeting between ORNL and Energy Impact Associates (EIA) has been scheduled for the end of September to discuss the ER.

Grace - A meeting took place at DOE in Germantown on August 1 to discuss the Grace ER. It was determined that deficiencies in the ER were due, at least in part, to barriers in channels of communication, i.e., ORNL could not deal directly with Envirosphere. As a result of this meeting, more direct communication has been established. ORNL attended a meeting at Envirosphere on August 6 to discuss comments on the Grace Draft ER. Grace/Ebasco/Envirosphere took the firm position that: (1) no additional field daca would be provided other than in the areas of air quality and aquatic ecology; (2) our requests for additional information, especially in the socioeconomic area, were unjustifiable and excessive. Although many telephone calls have been made to both DOE and Envirosphere; some deticiencies in the ER st1ll appear unresulved. The persisting problem areas are Noise, Traffic, and Geohydrulugy.

The Final ER is due on October 1. If the Final ER is complete and contains the necessary information, the PDEIS will be completed by January 1, 1980 .

ICGG - The ICGG Scoping Meeting was held at Cutler Auditorium, Cutler, Illinois, on August 15. The meeting proceeded smoothly. Most of the public's concerns related to employment prospects. ORNL's detailed comments on the Draft ER were sent to DOE on August 3. These were integrated with comments from HQ, PETC, and COE, Huntsville, in a letter to ICGG on August 23.

The Final ER should be received some time in mid September and completion of the PDEIS is then anticipated in mid December. 
CONOCO - Another draft of the environmental contract modification last discussed in April was sent to ORNL for comment. We found it to be satisfactory with the exception that our recommendation for a spring spawning study was rejected.

ORNL proposed a briefing meeting with EIA, similar to those held quarterly for MLGW. This has been placed on the agenda for the monthly review meeting in early September.

It is our understanding that the Draft ER is due to CONOCO in November. It will be submitted to DOE after review. The delivery date to ORNL is still uncertain.

A draft Notice of Intent and Implementation Plan has been prepared and sent to DOE. 


\subsection{Communications}

a. Boston, DeCicco, Witten, and Zittel attended a meeting in Germantown (DOE/FE) on August 1 to discuss ORNL's comments on the Grace Draft ER.

b. Boston, DeCicco, and Row met with Bob Martin (DOE/ORO) at ORNL on August 2 to discuss schedules for the.SRC-EISs.

c. Triegel attended a conference of the Soil Sciences Society of America in Denver on August 6-9.

d. Boston and Zittel attended a meeting at DOE/ORO on August 9 to discuss problem areas as perceived by E. A. Lloyd (DOE/FE) and H. T. Jones $(\mathrm{DOE} / \mathrm{FE})$.

e. Witten attended the ICGG Scoping Meeting dry run at DOE (Germantown) on August 9.

f. Boston, Row, and Zittel attended a meeting at DOE/ORO on August 13 to discuss problem areas.

g. Boston, DeVault, Kornegay, Kroodsma, Triege1, and Witten attended the ICGG Scoping Meeting and site visit on August 15-16.

h. Boston attended the Grace Monthly Progress Review Meeting in Memphis on August 16-1.7.

i. Witten attended the MLGW Monthly Progress Review Meeting in Livingston, N. J. on August 22-23.

j. France attended a meeting wilh Gulf and Stearus-Rügir on August 22 to review plant descriptions and design alternatives for SRCII.

k. Boston and DeCicco attended a meeting in D. C. on August 23 to discuss schedules, implementation plans, notices of intent, EIS contents, and related matters for the SRC-I and SRC-II projects.

1. DeCicco, DeVault, and Triegel participated in an SRC-II progress review meeting on August 30 in Denver.

\subsection{Milestones}

Preliminary draft environmental statements (PDES's) will be completed three months after receipt of acceptable, final environmental reports (FER's) from the industrial partners. Current schedules, contingent on delivery of FER's, call for PDES's, as follows: Grace, 1-2-80; SRC-I, 1-2-80; SRC-II, 1-2-80; ICGG, 12-15-79; MLGW, 12-15-79; CONOCO, 2-1-80. 


\title{
9. MAGNETIC PREPARATION OF DRY CRUSHED COAL
}

\author{
E. C. Hise and A. S. Holman
}

\subsection{Objective}

The objectives of this program are: to develop, demonstrate, and bring to commercial viability the removal of pyrite and ash-forming minerals from dry crushed coal by either or both processes of high-gradient magnetic separation (HGMS) and open-gradient magnetic separation (OGMS); to integrate the magnetic process into the coal preparation system to achieve the most effective and economic preparation of the raw coal; and to develop processes to minimize refuse disposal by efficiently utilizing the heating value and concentrated mineral resources in that refuse.

\subsection{Status Summary}

A visit was made to Sala Magnetics, Inc., to review the current status of the carousel continuous separation test. Presently, Sala expects to begin operating the carousel around october 1,1979 . The carousel at Sala is being converted from its typical wet transport to dry transport for the test series. During the visit, arrangements were completed with TVA to supply Sala with. 25 tons of Kentucky No. 9 for the test series. Sala is performing separability tests on a Lower Kittaning coal for Pennsylvania Power and Light (PP\&L). If the separability tests are acceptable to PP\&L, then they have also agreed to supply Sala with 25 tons of coal to be used as the second coal sample for the test series. We are also in the process of performing separability tests on a Lower Kittaning to see if our results agree with Sala's. During this trip, a tour of the Francis Bitter Magnet Laboratory was arranged to view the magnet facilities available.

While at the Advanced Coal Cleaning Conference held in Rindge, New Hampshire, Mr. Chris Mills of Behre, Dolbear, and Associates, Inc., became extremely interested in our work and offered to try to separate a sample of Kentucky No. 9 using an induced roll magnet. A Kentucky No. 9 sample was sent to Reading U.S., Inc., who performed separation lests. Reading has notified us that the induced roll separator removed approximately $22 \mathrm{wt} \%$ as magnetics in four passes. Gravimetric and magnetic separations of similar samples of Kentucky No. 9 have produced good mineral reduction and BTU recovery at around 22 wt \% rejection. However, chemical analyses of the product and magnetics, when they are returned, will be required to determine if this separation was effective.

The contract with Powe11 Construction Company for a process flow sheet of the magnetic circuit has been negotiated. 
In-house testing of coal samples from United Coal Companies is continuing, and the chemical comminution experiment with TVA is set up and in operation.

The analytical tools for modeling different magnet configurations for open-gradient magnetic separation continue to be developed. At present, there are models for the Frantz Isodynamic and for an infinite radius solenoid that produce in graphic or tabular form the total field, the X-component of the field, the Y-component of the field, and the field gradient in the $\mathrm{X}$-direction as a function of $\mathrm{X}$ and $\mathrm{Y}$ position. Another model is capable of determining the trajectory of a particle, described by its physical and magnetic characteristics, as it passes through a magnetic field. 'Ihis model can now be operated with the isodynamic field model and is being integrated with the infinite radius model.

Figure 9.1 is a graphic presentation of the field formed by two opposing (cusp mode) infinite radius solenoids, each $12.5-\mathrm{cm}$ high by $1-\mathrm{cm}$ thick, with no separation between them, and a current density of 30,000 amps $/ \mathrm{cm}^{2}$. The field is plotted along a line $1 \mathrm{~cm}$ from the edge of the conductor for the $25-\mathrm{cm}$ length of the magnet. The force acting in the $\mathrm{X}$-direction on any particle within a magnetic field is proportional to the product of the total field and the $\mathrm{X}$-gradient. For this particular calculation, that product is around $54 \times 106$ Gauss $2 / \mathrm{cm}$, which is quite close to that calculated for the Frantz Isodynamic. These calculations are preliminary and do not necessarily represent a realizeable configuration; however, they do show an emerging capability for modeling and indicate a possibility of an open-gradient separator.

Installation of our superconducting magnet continues to be delayed pending preparation of one lab area. The rooms have now been cleaned and are currently being painted. 


\section{Infinite Radius Solenoid}

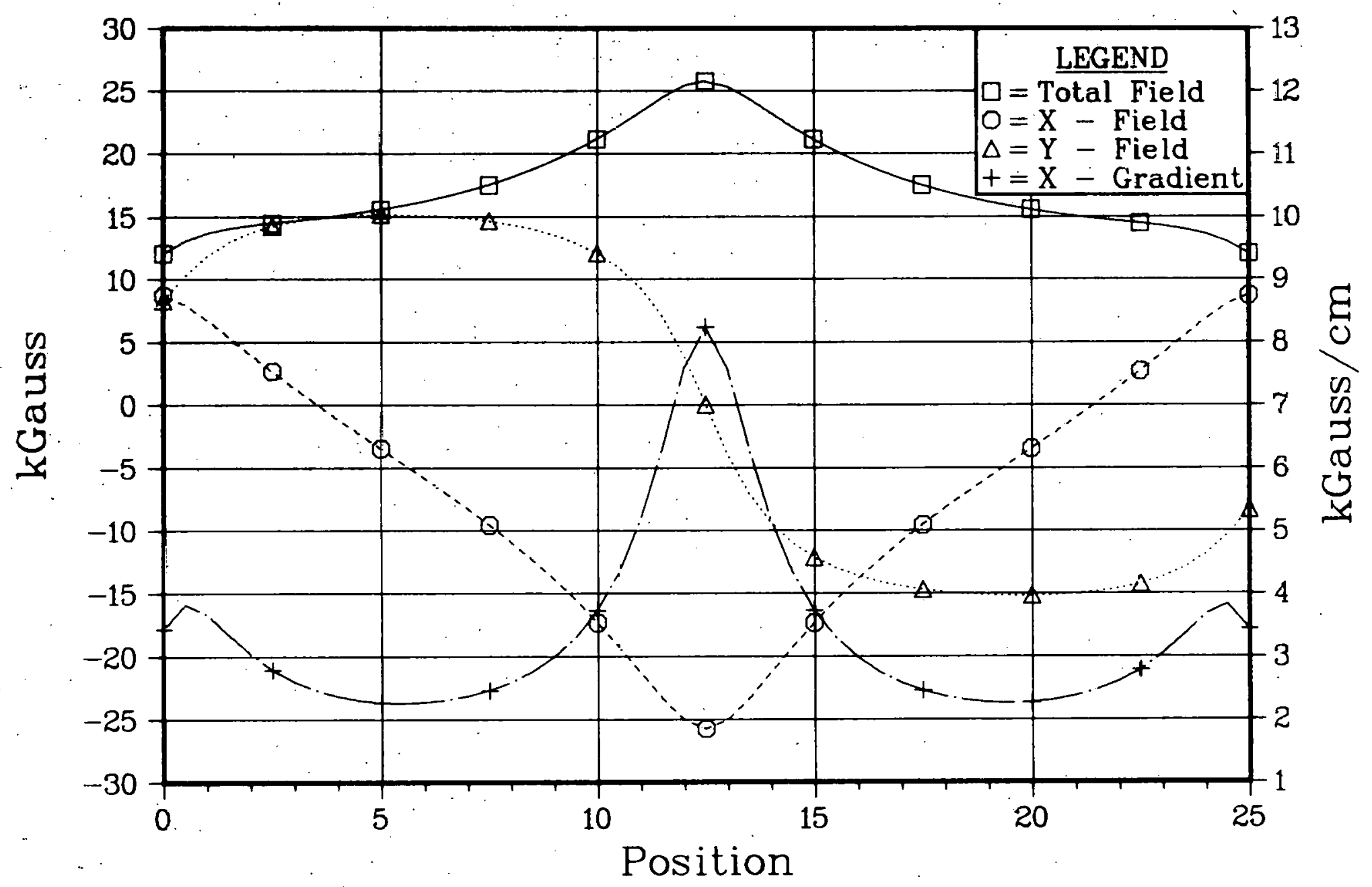

Figure 9.1. Plot of the magnetic field formed $1-\mathrm{cm}$ from the conductors by two opposing (cusp mode) infinite radius solenoids each $12.5-\mathrm{cm}$ high by $1-\mathrm{cm}$ thick with no separation between the solenoids and a current density of $30,0100 \mathrm{amps} / \mathrm{cm}^{2}$. 


\section{ATMOSPHERIC FLUIDIZED BED COAL COMBUSTOR FOR COGENERATION (AFBCCC)}

R. S. Holcomb

\subsection{Objective}

The Coal Combustor for Cogeneration (CCC) Program is directed at the development of a fluidized bed coal combustion system heating air inside tubes to provide high temperature clean air to drive a gas turbine to generate electricity. The heat in the air leaving the turbine exhaust would be recovered to supply industrial process heat. The gas turbine is very well suited for cogeneration since the ratio of thermal to electrical energy is about 3 to 1 . for the gas turbine cycle as compared to $a$ ratio of about 5 to 1 for a back-pressure steam turbine, and the exhaust heat from the gas turbine is available at a higher temperature. The scope of the program Includes the study of Industrlul cogeneration plants in the size range from 5 to $50 \mathrm{MW}(\mathrm{e})$ and the construction and testing of a $0.3 \mathrm{MW}(\mathrm{e})$ technology test unit.

\subsection{Status Summary}

The evaluation of the CCC proposals was completed the first week of August. The evaluation team selected the proposal submitted by a team composed of Westinghouse, Babcock and Wilcox, and Stone and Webster as the best proposal and recommended that they be awarded the program subcontract. A review of the evaluation and the recommendation for award was presented to the management of the DOE-FFU Division in a meeting held in Washington on August 10. OKNL was given approval by DOE'F'F' to proceed to negotiate a subcontract with the Westinghouse team to implement the CCC program.

The Westinghouse team proposal included seven tasks: Conceptual Design of a 20-25 MW(e) Reference Plant, Design and Construction of a $200 \mathrm{KW}(\mathrm{e})$ Test Unit, Test Program, Preliminary Design of a Site Specific Demonstration Plant, Gas Turbine Compatibility Study, Extended Application Studies, and Commercialization Plan. Each of these tasks would be performed in its entirety by the subcontractor team with the exception of the Design and Construction of the Test Unit and the Test Program. The test combustor and its major associated equipment would be designed and fabricated by Babcock and Wilcox. They would also prepare specifications for other major components in the test system for procurement by ORNL. ORNL will be responsible for installation of the test system. equipment at the Y-12 Plant site. The test program will be conducted jointly by ORNL, Westinghouse, and Babcock and Wilcox.

Purchasing Division representatives met with Westinghouse, Babcock and Wilcox, and Stone and Webster during the last week in August to discuss the legal terms and conditions for the subcontract. Further negotiations are planned and it is anticipated that the terms can be 
agreed upon in a period of two to three months. Meanwhile, a request will be made to the Westinghouse team to begin work on the design of the Reference Plant and the Test Unit as soon as possible on the basis of a Letter of Intent to place a subcontract upon reaching agreement of terms and DOE approval.

The work statement for the subcontract is being prepared by ORNL and discussions will be held with the Westinghouse team to reach agreement. It will be based on their proposal as submitted with amendments to clarify the level of effort and scope of responsibility and to insure a clear understanding of the work agreed upon. The amendments will include the requirements for the design and fabrication of the test system components and equipment. 


\title{
11. TENNESSEE VALLEY AUTHORITY (TVA) FLUIDIZED BED COMBUSTION (FBC) DEMONSTRATION PLANT PROGRAM TECHNICAL SUPPORT
}

\author{
$\mathrm{J}$. E. Jones Jr.
}

Tennessee Valley Authority has assumed a lead role in the demonstration of FBC technology for application in large utility boilers. ORNL will provide technical support and services to TVA in FBC systems. This work is to support TVA Energy Research's objective to develop FBC systems for utility electric power generation which will burn high-sulfur coal and meet environmental emission standards.

TVA will be the lead agenry in this work and will reimburse DOE for the work to be performed by ORNL. This work is to be conducted by ORNL under the terms and conditions of the Interagency Agreement between IVA, DOE, and ORNL regarding support for FBC research (reference: Agreement TV-48296A, Subagreement 5).

\subsection{AFBC Technology Support - Task 2 \\ M. Siman-Tov and J. E. Jones Jr.}

\subsubsection{Contract objective}

The objective of this program is to provide technical support of a general nature in FBC systems and respond to specific requests from TVA personnel. Such requests may include reviews, assessments, participation in TVA tasks, and similar activities.

\section{1 .2 Status summary}

A review of proposals from Babcock \& Wilcox and Combustion Engineering to design and build an AFBC pilot plant for TVA has been initiated and practically completed this past month. The review was undertaken by a multidiscipline team which involved ORNL Engineering, Engineering Technology Division, Chemical Technology Diviston, Melals and Ceramics Division, and Instrumentation and Control Division.

Two meetings have been held with TVA personnel from the Energy Demonstration and Technology Section in Chattanooga to convey our comments and explain our position on various issues. Also, a preliminary summary letter was drafted and submitted to TVA which included 43 comments and discussions on a number of issues of specific concern to TVA.

A substantial difference between the two proposals was found in both scope and presentation. The areas that seem to be of major concern include the operational procedures (which in both cases involves slumping techniques), feed distribution and conveying, and control and instrumentation for both operation and data collection. Problems involving design and material compatibility are also included. Specific key issues were 
discussed in more detail to assist TVA on possible modifications in their request for proposals. That includes the justification for a carbon burn-up cell (CBC), a reduction in superficial velocity requirement, the minimum initial feed points distribution, and the scope and extent of instrumentation required.

A formal summary letter is being prepared to be delivered to TVA before the Board of Directors meet to decide on the issue sometime in mid-September.

\subsection{4 x. 4 Cold Flow Model - Task 3}

R. S. Holcomb and M. E. Lackey

\subsubsection{Contract objective}

The objective of this task is to experimentally investigate slumping of a portion of a fluidized bed using a sub-scale cold flow model. The scope of work includes design and minor modification of the $4 \times 4$ cold flow model for slumping and refluidization tests and conducting bed slumping tests.

\section{2 .2 Status summary}

Design and Modifications - The fluidizing-air plenum will be redesigned so that the air can be shut off to a portion of the $4 \times 4$ bed with the air flow continuing to the other portion. A new simulated tube bundle will be designed for the slumping tests. The design will be based on a $1 / 4$ scale factor - i.e., the tube diameter, bed depth, and fluidizing velocity will be $1 / 4$ that of the full-scale FBC boiler. The cold flow model will be modified to incorporate the design changes.

Testing - Tests will be conducted to investigate the effects of slumping a portion of the bed and continuing operation of the remainder. Observations will be made to study mixing between the active and slumped portions, fluidizing air bypass through the slumped section, elutriation from the fluidized section and deposit in the slumped section, and maximum buildup of the slumped bed. The fluidizing air will then be turned on to the slumped portion, and the action of the two sections will be studied during refluidization. These tests will be done over a range of fluidizing velocities from 1 to $2 \mathrm{ft} / \mathrm{sec}$ and bed depths from 1 to $1.5 \mathrm{ft}$ to represent scale studies of values four times as large. Other operating data will be obtained incidental to these tests.

Progress to date - During the preliminary bed slumping tests that were conducted with a static bed depth of approximately $11-1 / 2$ in, it was determined that the limestone bed expanded approximately $35 \%$ at a superficial velocity of $2 \mathrm{ft} / \mathrm{sec}$. Limestone was added to the bed to give a static bed height of approximately 3-3/4 in. and an expanded bed height of $1 / 5 \mathrm{ft}$ when operating at a superficial velocity of $2 \mathrm{ft} / \mathrm{sec}$. 
The fluidizing characteristics of the bed are shown in Figure 11.1. As can be seen from the data shown in Fig. 11.1, the minimum fluidizing velocity is approximately $0.5 \mathrm{ft} / \mathrm{sec}$. It should also be noted from the data of Fig. 11.1 that the system is not fully fluidized until the superficial velocity approaches a value of approximately $1 \mathrm{ft} / \mathrm{sec}$ or twice the minimum fluidizing velocity.

After determining the fluidizing characteristics of the system, a slumping test was conducted with a nominal superficial velocity of $2 \mathrm{ft} /$ sec in the fluidized section of the bed. The static contour of the bed as a function of operating time is shown in Fig. 11.2. As can be seen from inspection of Fig. 11.2, the solids distribution had reached a state of quasi-equilibrium after an operating period of approximately $4 \mathrm{hrs}$. Slip planes were detected between the slumped bed and the fluidized bed. Figure 11.3 indicates the approximate magnitude of the planes. In the regions of the planes, a downflow of the solids was observed during the operation of the bed.

The bed pressure and velocity distributions at 3 in. above the air inlet nozzles are shown in Figures 11.4 and 11.5. These data were obtained with various flows being maintained through the slumped section of the bed. The data at a slumped section average superficial velocity of $0.252 \mathrm{ft} / \mathrm{sec}$ was obtained with all of the air being supplied to the fluidized side. The $0.252 \mathrm{ft} / \mathrm{sec}$ represents the magnitude of the bypass when operating under these conditions. The higher velocities in the slumped region were obtained by supplying air to the windbox in an attempt to increase the pressure gradient in the slumped bed and thereby reduce the leakage between the fluidized and slumped sections. A solids distributions test will be conducted with an average superficial velocity of $0.462 \mathrm{ft} / \mathrm{sec}$ in the slumped section and an average velocity of $2 \mathrm{ft} / \mathrm{sec}$ in the fluidized section to determine the effects upon the solids build-up of the approximately minimum fluidizing velocity in the slumped region.

\subsection{AFBC Modeling and Simulation - Task 4}

J. W. Wells and R. P. Krishnan

\section{$11: 3.1$ Contract objective}

The objectives of this program are to develop a simple steady-state model for conceptual design of the main cell and carbon burnup cell and to incorporate in this model the ability to predict trends in bed performance under various feed and operating parameters.

\subsubsection{Status summary}

During this month, the ORNL attrition-elutriation model was used to predict the performance of the B\&W $6 \times 6$ AFBC based on test series 5 and 6 performed in November 1978 and February 1979, respectively. The code uses the elutriation and attrition rate expressions of Highley and 


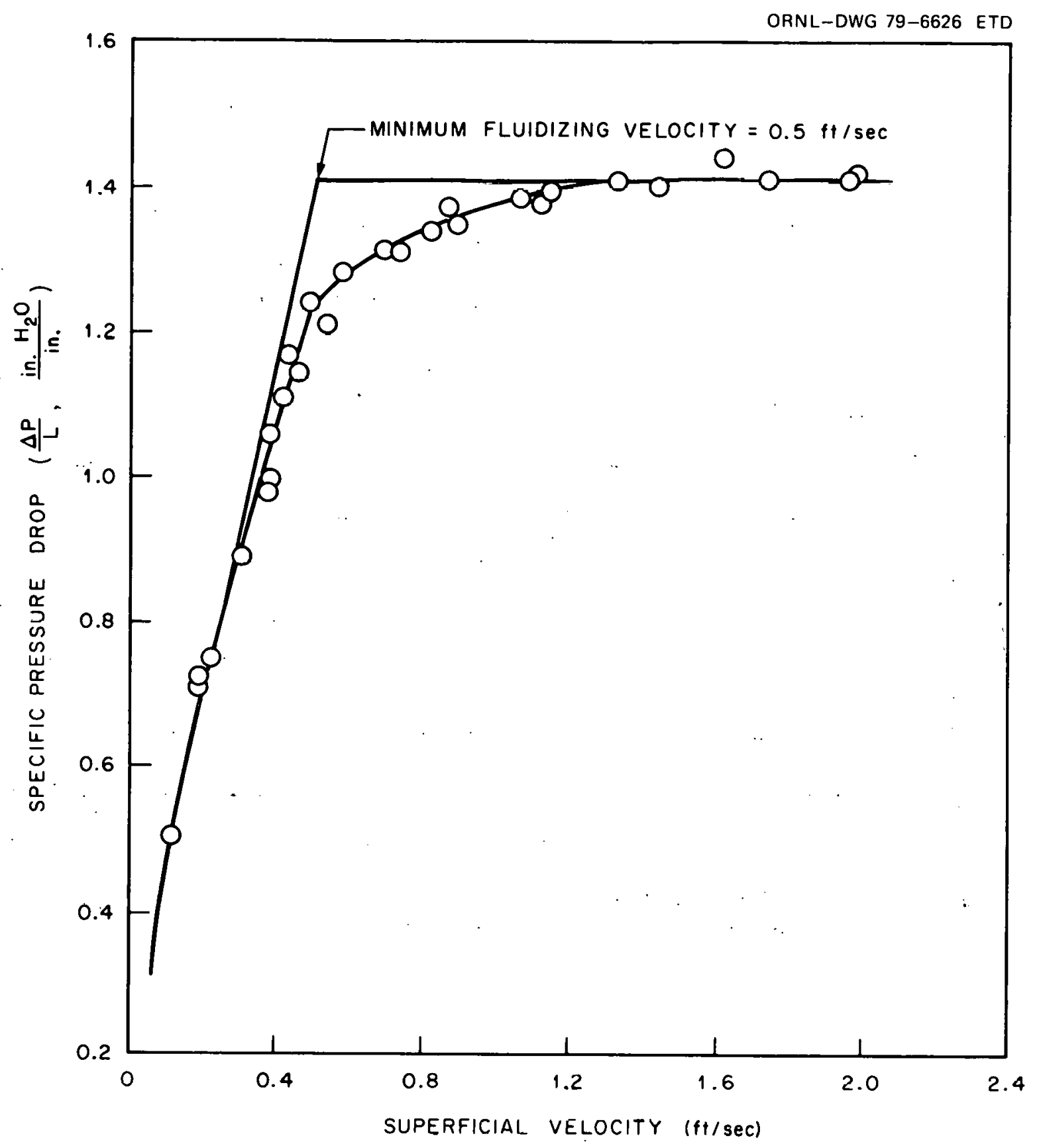

Figure 11.1. Fluidizing characteristics of Quincy Limestone, size $20 \times 60$. 


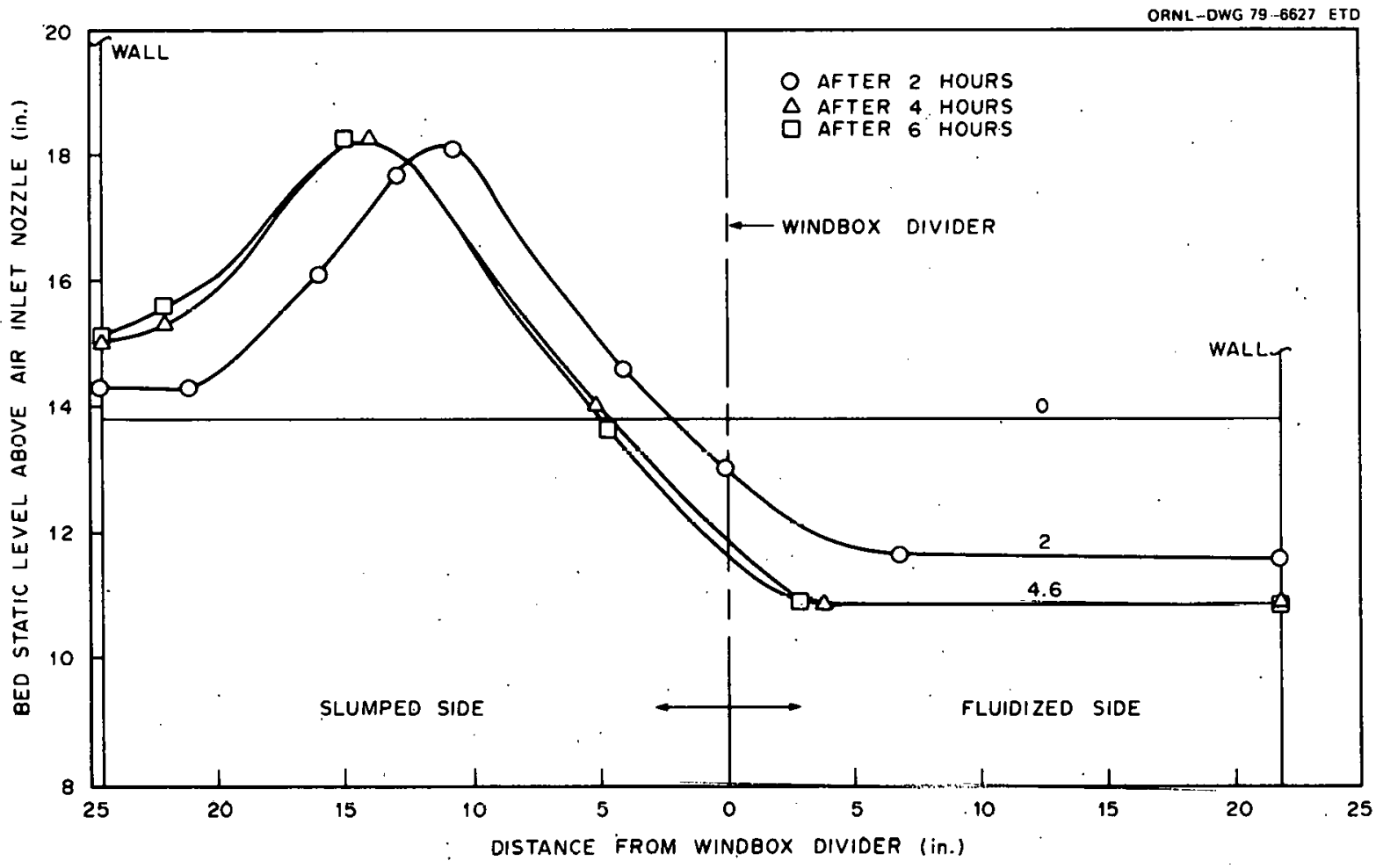

Figure 11.2. Solids distribution after operation for 2,4 , and $6 \mathrm{hr}$ at a superficial velocity of $2 \mathrm{ft} / \mathrm{sec}$. 


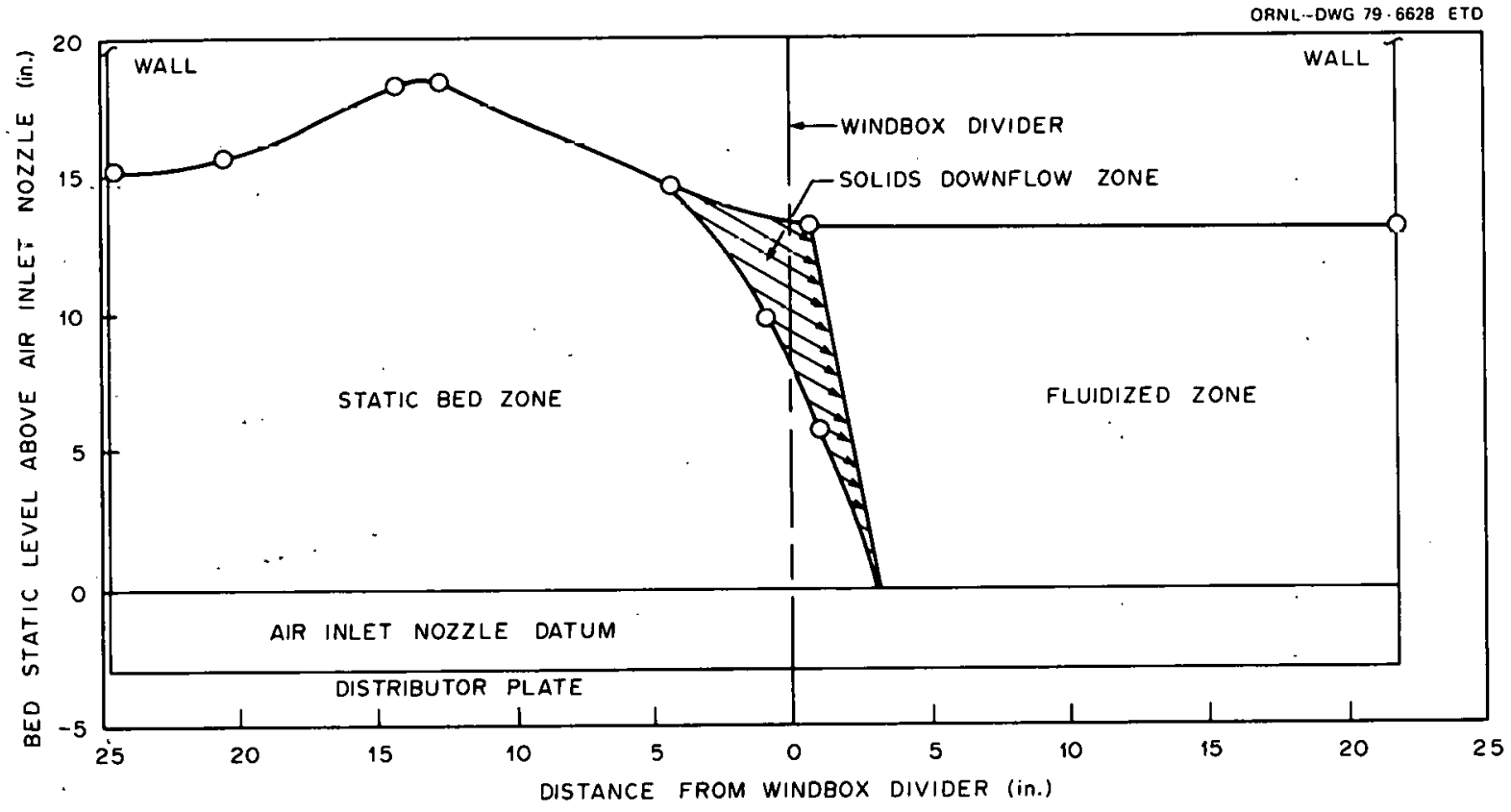

Figure 11.3. Solids distribution after operation for $6 \mathrm{hr}$ at a superficial velocity of $2 \mathrm{ft} / \mathrm{sec}$. 


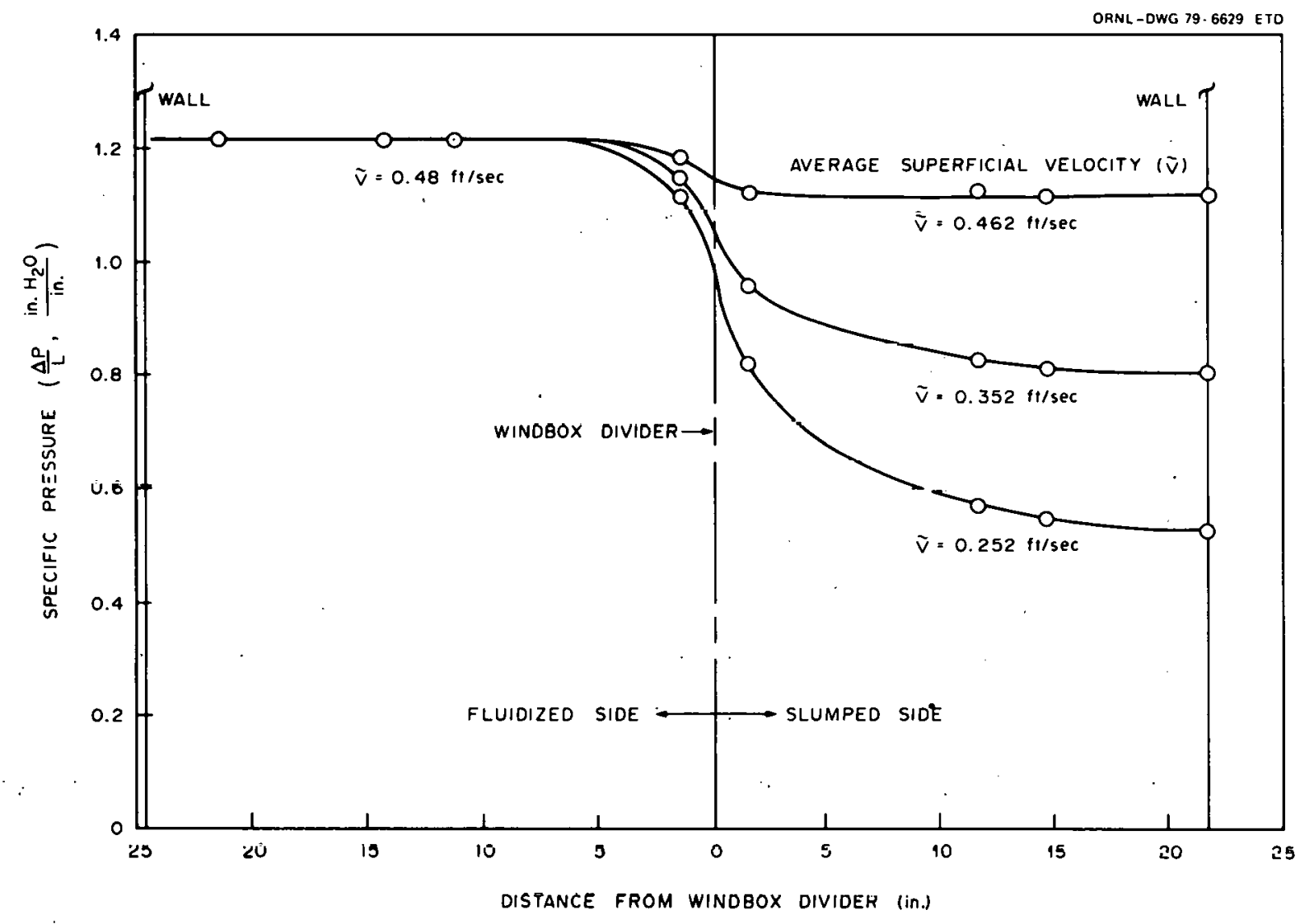

Figure 11.4. Bed pressure distribution at 3 in. above the air inlet nozzles with various slumped bed flows. 


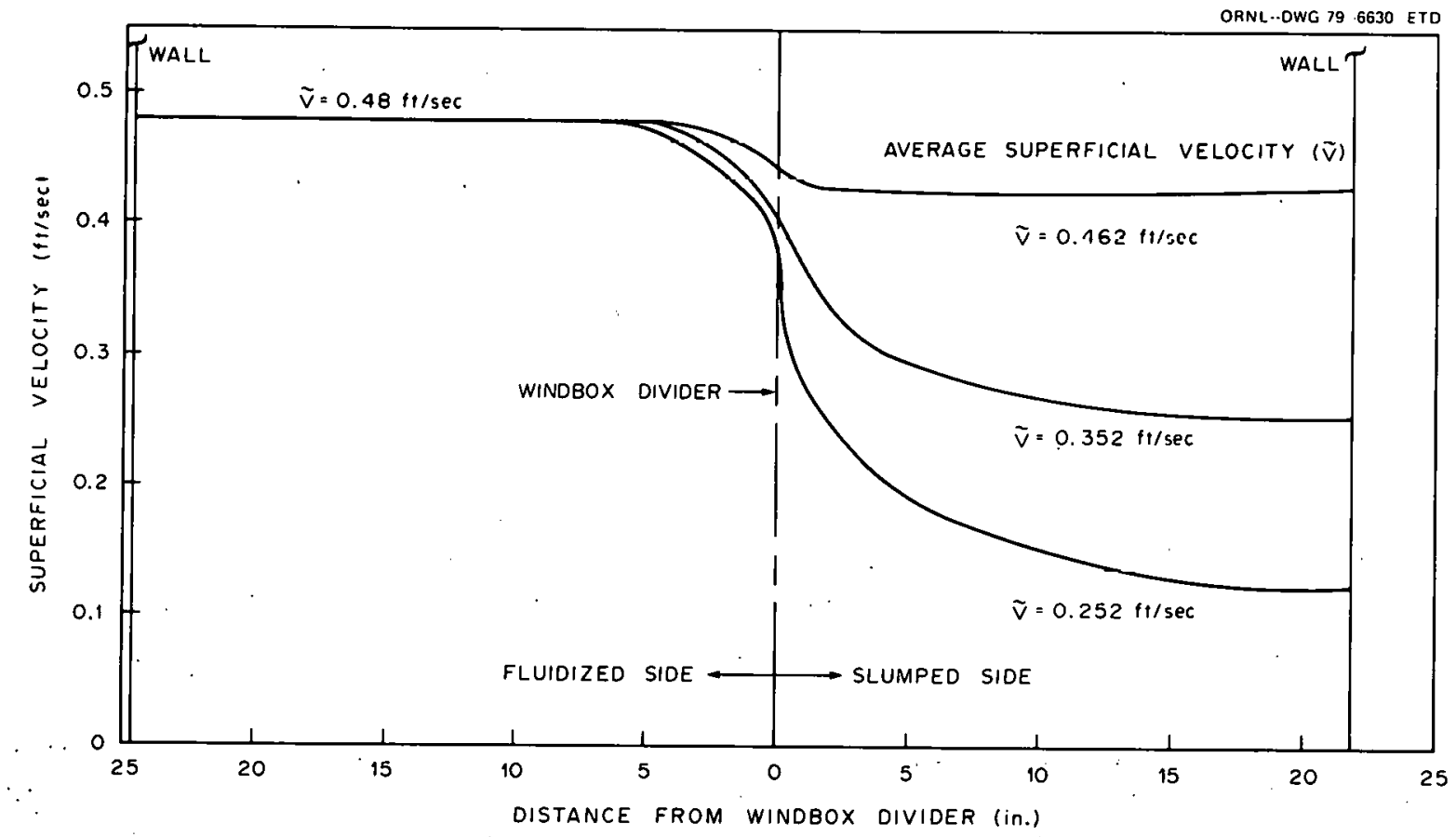

Figure 11.5. Estimated bed superficial velocity distribution with various slumped bed flows. 
Merrickl. The preliminary results of simulation are shown in Fig. 11.6 and are summarized in Table 11.1. The differential particle size distribution for the feed material in the bed and for the elutriated solids are presented. These results predict that $21.1 \mathrm{gm} / \mathrm{sec}(22 \%)$ of inlet limestone solids are blown out of the cell and that about half of this ( $11.6 \mathrm{gm} / \mathrm{sec}$ or $12 \%$ ) is caused by attrition.

Table 11.1. Results from ORNL attrition-elutriation code for B\&W tests conditions performed during 1979 .

\section{Inputs}

Limestone feed rate $-94.5 \mathrm{gm} / \mathrm{sec}$

Superficial velocity - $234.7 \mathrm{~cm} / \mathrm{sec}$

Height of bed $-121.2 \mathrm{~cm}$

\section{Outputs}

Total limestone solids elutriated - $21.07 \mathrm{gm} / \mathrm{sec}$

Limestone solids underflow $-73.4 \mathrm{gm} / \mathrm{sec}$

Weight of limestone solids in bed $-2.44 \times 10^{6} \mathrm{gm}$

Attrition is the reduction of the solids particle size by abrasion of the particles with the walls, with the internals and among themselves. Preliminary estimates from experimental data ${ }^{2}$ indicate that roughily $4 \%$ of the bed weight is attrited in an hour. The calculations based on the $4 \%$ estimate yield an attrition rate for the overall bed of $27.11 \mathrm{gm} / \mathrm{sec}$, as compared to $11.6 \mathrm{gm} / \mathrm{sec}$ predicted by the model. Also, the B\&W data indicate that in the $6^{\prime} \times 6^{\prime}$ unit, $35 \%$ to $60 \%$ of the inlet limestone solids are elutriated ${ }^{3}$ compared to $22 \%$ predicted by the model.

In order to resolve this disagreement, the data from the $B \& W$ experimental series 5 and 6 were analyzed and correlated. Specifically, the total rate of limestone solids elutriated and the rate due to attrition were calculated from the data. This was done by making the following assumptions.

1. The bed drain (overflow) is assumed to be all limestone solids.

2. It is assumed that all limestone particles below a certain critical size are blown out of bed.

The series 6 data were correlated by the following equation.

$$
\operatorname{ATT}=6.74 \mathrm{dp}(\mathrm{FD}) \mathrm{U}_{\mathrm{o}} \tau^{-1.224},
$$




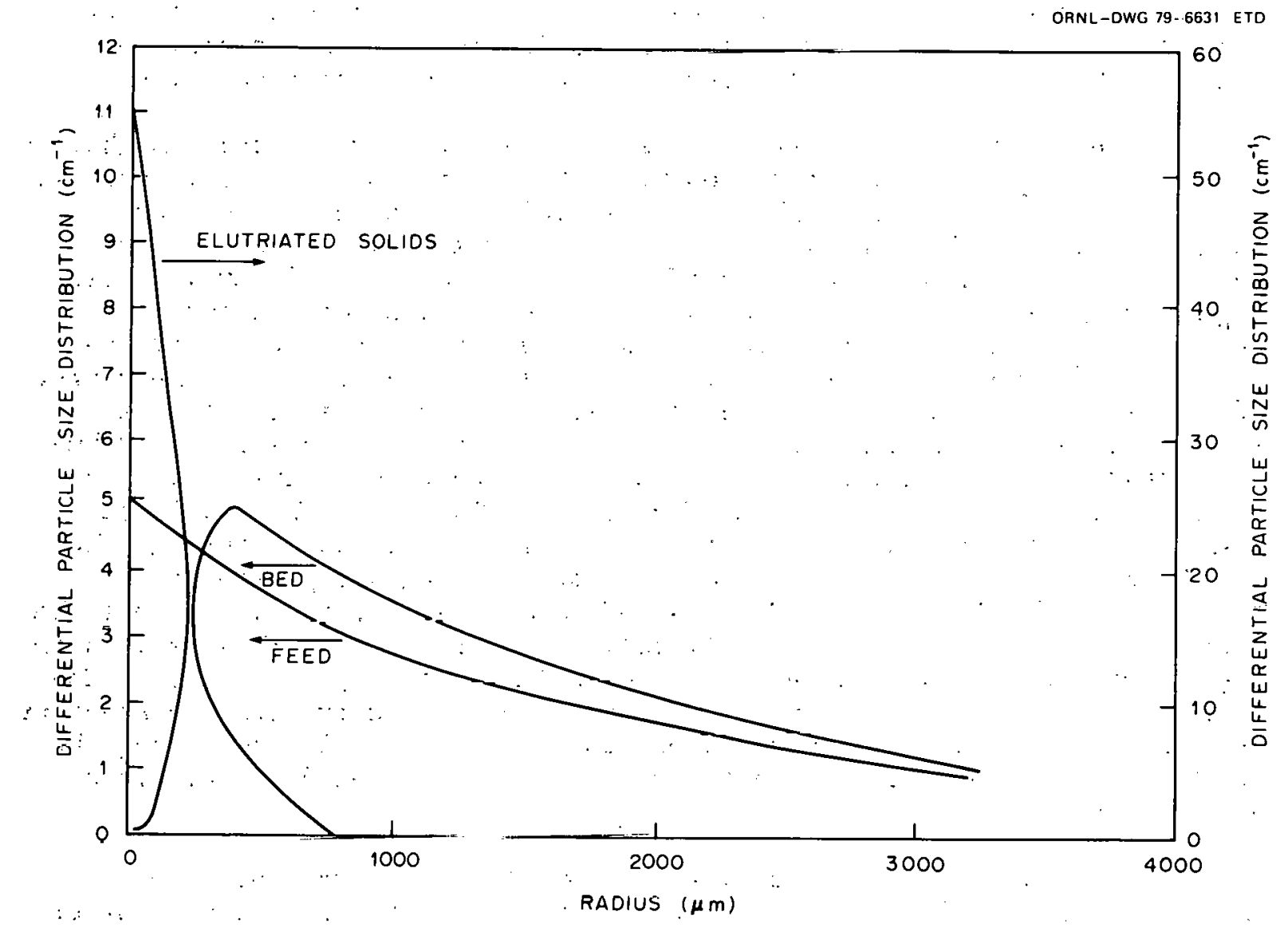

Figure 11.6. Preliminary results of ORNL code with Highley \& Merrick attrition and elutriation. 
where:

$$
\begin{aligned}
\mathrm{ATT}= & \text { attrition rate, } \mathrm{gm} / \mathrm{sec}, \\
\mathrm{dp}(\mathrm{FD})= & \text { weight mean of limestone feed, } \mathrm{cm}, \\
\mathrm{U}_{\mathrm{O}}= & \text { superficial velocity, } \mathrm{cm} / \mathrm{sec}, \\
\tau= & \text { weight space time (weight of the bed divided by limestone } \\
& \text { flow), hr. }
\end{aligned}
$$

This fit of the data and the derived correlation are shown in Fig. 11.7. However; the correlation does not fit well with the series 5 data.

Between series 5 and 6 , the feed system was modified by enlarging some of the solid transport piping from 1-1/2 in. to 2-in. in diameter. This may have caused the difference in the observed attrition rates.

In analyzing the $B \& W$ data another contradiction was noted. Highley and Merrick ${ }^{1}$ and Geldart ${ }^{3}$ have reported that there is a critical particle size in a fluid bed, beluw which all. particlco are blown nit nf the hed. Only particles larger than the critical size remain in the bed. For inert bed material such as ash and limestone, the critical particle size is given by Highley and Merrick as 1.6 times the size of the particle having a terminal velocity equal to the superficial velocity. For the $\mathrm{B} \& W 6^{\prime} \times 6^{\prime}$ conditions, this particle size is around $1270 \mu \mathrm{m}$. Therefore, the size distribution of the bed material can be expected to start at around this size. Analysis of the $B \& W$ data shows that bed size distribution starts at $300 \mu \mathrm{m}$ and above for all runs reported. This is contrary to the observation of Highley and Merr1ck dud Geldart. This could be due to the decrease in the velocity of the gas as it passes through the freeboard convection section. No freeboard cooling was present in Highley and Merrick's bed. For the B\&W data freeboard, cooling lowers the flue gas temperature from approximately $1600^{\circ} \mathrm{F}$ iu $700^{\circ} \mathrm{F}$. This reaulte in an increase in gas density and a decrease in the flue gas velocity. The flue gas cannot carry the larger particles beyond the ficibuard conventinn bundles. These particles disengage from the gas and fall down along the walls into the bed. The BdW data from series 4, 5, and 6 support this liypothesis.

This shows that theisize distribution of the cyclone catch is always $300 \mu \mathrm{m}$ and less, and that of the bed is always $300 \mu \mathrm{m}$ and larger. It appears that particles larger than $300 \mu \mathrm{m}$ but smaller than $1270 \mu \mathrm{m}$ may be trapped in the bed-freeboard convection sections and attrited down to $300 \mu \mathrm{m}$ before they are released to the cyclones.

In summary, during this month the ORNL attrition-elutriation code was used to simulate the $B \& W 6^{\prime} \times 6^{\prime}$ type conditions. The results from this code did not agree with the B\&W data.

Analysis of the $B \& W$ data established a correlation for prediction of attrition and showed that the attrition rate is dependent on the solid feed system configuration. Also, this analysis showed that the presence of a freeboard convective section may affect the amount and particle size of solids blown out of the bed. 


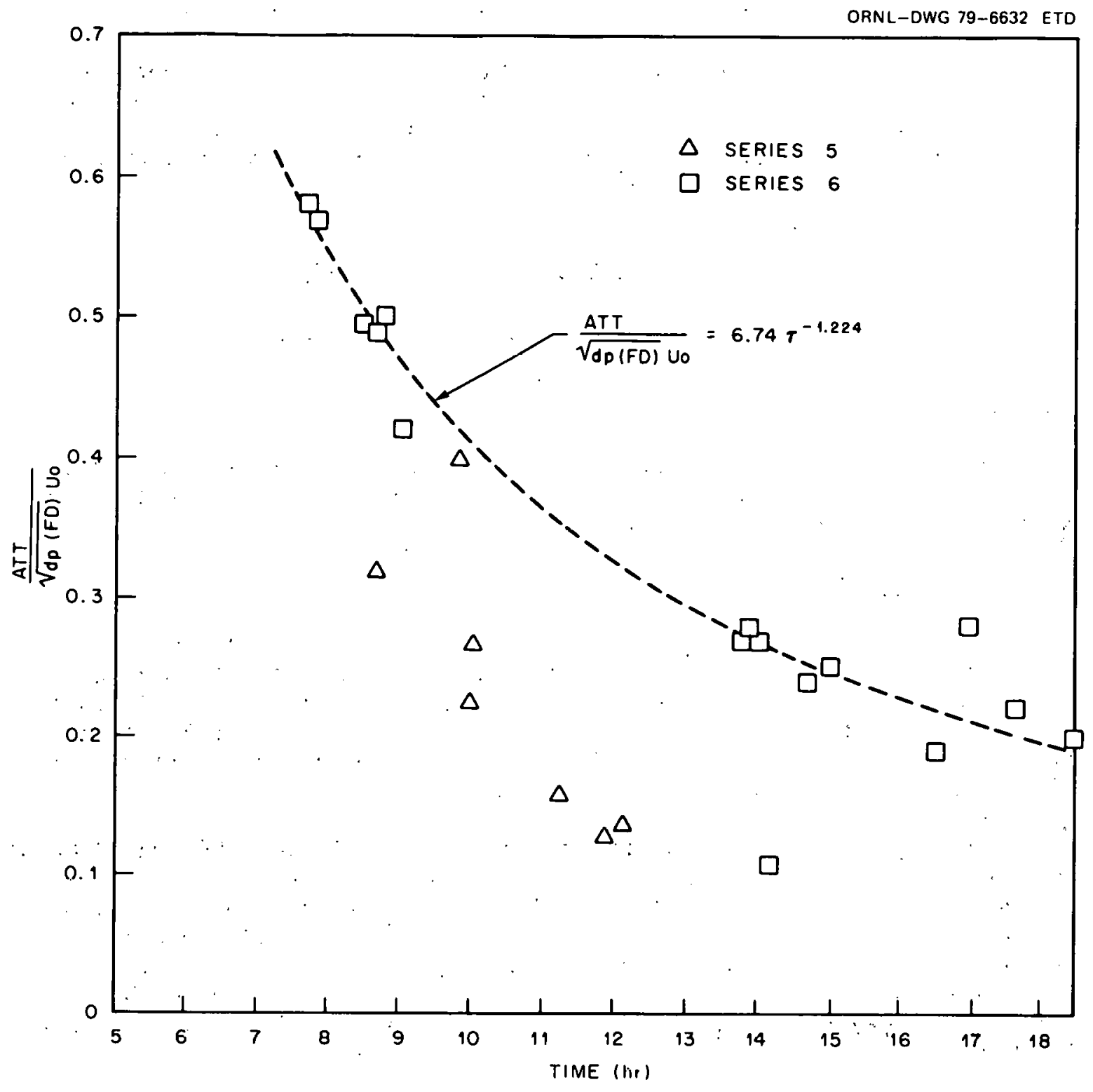

Figure 11.7. B\&W attrition data. 
The effects of the feeding system and convection cooling in the freeboard on attrition have not been previously considered in the literature. 45 Discussion with $B \& W$ and others will be necessary to confirm these ideas and establish experimental programs to quantize these effects.

The present ORNL model does not incorporate these phenomena, but they will be included when their validity is established and quantized (hopefully next year). During the upcoming month, ash attrition and elutriation will be modeled and work will begin on the combustion and sulfur capture codes.

\subsection{AFBC Bench Scale Facility - Task 5}

R. S. Holcomb, R. H. Guymon, and G. P. Zimmerman

\section{4 .1 Contract objective}

The objective of this task is to experimentally investigate heat transfer, sulfur capture, carbon loss, and combustion of recycle carbon using the ORNL AFBC bench scale combustor.

\section{4 .2 status summary}

Test facility description - The combustor is 10-in. ID and about 15-ft tall. The combustor is designed for burning 10 to $30 \mathrm{lb} / \mathrm{hr}$ of coal and is equipped for limestone addition. The system is designed to operate with a bed fluidizing velocity in the range of 4 to $10 \mathrm{ft} / \mathrm{sec}$ and bed temperatures up to $1600^{\circ} \mathrm{F}$. The bed is cooled by compressed air flowing through $0.5-i n .-O D$ tubes immersed in the bed.

Test program - Heat transfer tcots will be done for 1000 and $1900 \mu \mathrm{m}$ mean size limestone over the fluidizing velocity range of 4 to $10 \mathrm{ft} / \mathrm{sec}$ at bed temperatures of 1400 to $1600^{\circ} \mathrm{F}$. Sulfur capture and carbon loss tests will be run for selected coals and limestones of interest to TVA for severa $\perp$ values of $\mathrm{Ca} / \mathrm{S}$ over a fluidizing velocity and temperature range similar to that for heat transfer. Tests to investigate the combustion of recycle char removed by the cyclone separator will be run for various operating conditions.

Progress to date - Ten coal combustion runs totaling 36 hours were completed during the month. Superficial velocities of 4,5 , and $6 \mathrm{ft} / \mathrm{sec}$ were investigated for sulfur capture. Test results for August appear in Table 11.2. Test results for the month of June, which have been reviewed and have been determined to be good data, are listed in Table 11.3. As mentioned in a previous report, no reliable data were obtained in July due to $\mathrm{SO}_{2}$ meter problems.

Table 11.2 indicates that for a superficial velocity of $6 \mathrm{ft} / \mathrm{sec}$ and a bed temperature of $1550^{\circ} \mathrm{F}$, a calcium to sulfur mole ratio of about $4.5: 1$ is required in order to achieve $90 \%$ sulfur capture. There is some test 
Table 11.2. AFBC sulfur capture results for August 3-7, 1979.

\begin{tabular}{|c|c|c|c|c|c|c|c|}
\hline $\begin{array}{l}\text { Date } \\
\text { Time }\end{array}$ & $\begin{array}{r}8-3-79 \\
14: 56\end{array}$ & $\begin{array}{r}8-3-79 \\
15: 32\end{array}$ & $\begin{array}{r}8-3-79 \\
15: 52\end{array}$ & $\begin{array}{r}8-7-79 \\
12: 51\end{array}$ & $\begin{array}{r}8-7-79 \\
13: 35\end{array}$ & $\begin{array}{r}8-7-79 \\
14: 06\end{array}$ & $\begin{array}{r}8-7-79 \\
14: 34\end{array}$ \\
\hline Bed temperature, ${ }^{\circ} \mathrm{F}$ & 1569 & 1581 & 1564 & 1551 & 1544 & 1549 & .1510 \\
\hline Superficial velocity, ft/sec & 6.1 & 6.2 & 6.1 & 5.9 & 5.8 & 5.9 & 5.8 \\
\hline Static bed depth, inches & 35 & 36 & 36 & 31 & 32 & 34 & 36 \\
\hline Coal feed rate, $1 \mathrm{~b} / \mathrm{hr}$ & 25.8 & 27.4 & 26.0 & 24.0 & 24.8 & 25.8 & 26.7 \\
\hline Limestone feed rate, $1 \mathrm{~b} / \mathrm{hr}$ & 4.5 & 5.9 & 6.25 & 7.8 & 8.7 & 9.9 & 9.9 \\
\hline Calcium/sulfur, mole ratio & 2.1 & 2.6 & 2.9 & 3.9 & 4.25 & 4.65 & 4.5 \\
\hline Combustion air flow, $1 \mathrm{~b} / \mathrm{hr}$ & 232 & 232 & 231 & 226 & 224 & 226 & 227 \\
\hline $\mathrm{O}_{2}$ in flue gas, percent & 3.1 & 2.0 & 2.75 & 3.15 & 3.0 & 3.0 & 2.9 \\
\hline Indicated excess air, percent & 16.9 & 10.3 & 14.7 & 17.3 & 16.4 & 16.4 & 15.7 \\
\hline Carbon utilization, percent burned & 87.0 & 87.0 & 87.0 & 79.7 & 79.7 & 79.7 & 79.7 \\
\hline $\begin{array}{l}\mathrm{SO}_{2} \text { in flue gas, } \mathrm{ppm} \\
\text { Sulfur capture (weight percent remo }\end{array}$ & 900 & 900 & 600 & 375 & 305 & 260 & 200 \\
\hline As-fed coal & 58.3 & 60.6 & 72.7 & 82.5 & 85.9 & 87.9 & 90.5 \\
\hline As-burned coal & 65.5 & 69.2 & 78.1 & 85.3 & 88.6 & 90.7 & 93.2 \\
\hline
\end{tabular}

Limestcne size: $12 \times 30$ mesh

Coal analysis: C $67.66 \%$

$\mathrm{H}_{2} \quad 4.66$

$\mathrm{O}_{2} \quad 5.79$

$\mathrm{N}_{2} \quad 1.33$

$\mathrm{H}_{2} \mathrm{O} 2.33$

$\mathrm{S} \quad 2.53$

Ash 15.7 
Table 11.2. AFBC sulĩu capture results for August 10-14, 1979.

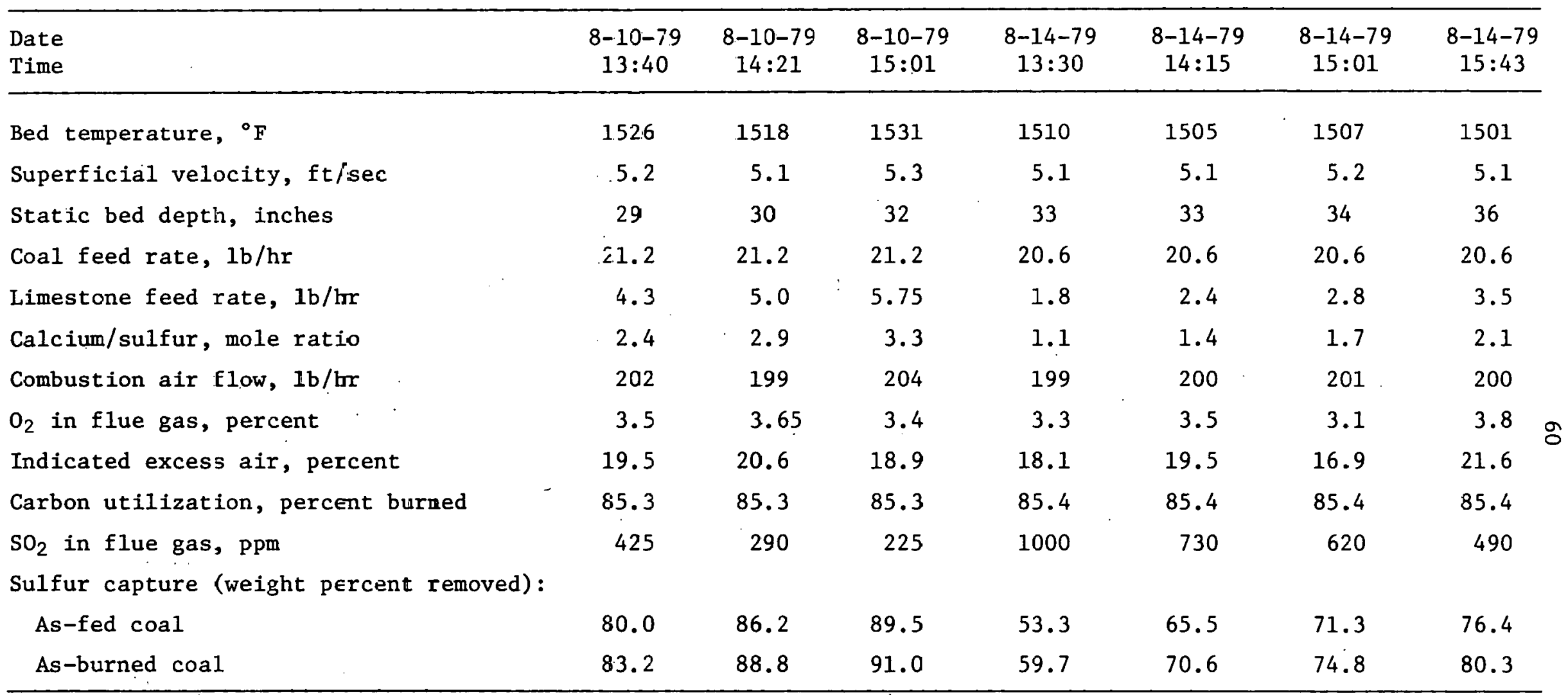

Limestone size: $12 \times 30 \mathrm{mesh}$

Coal analysis: C $67.66 \%$

$\mathrm{H}_{2} \quad 4.66$

$\mathrm{O}_{2} \quad 5.79$

$\mathrm{N}_{2} \quad 1.33$

$\mathrm{H}_{2} \mathrm{O} \cdot 2.33$

$\mathrm{S} \quad 2.53$

Ash 15.7 
Table 11.2. AFBC sulfur capture results for August 16-24, 1979 .

\begin{tabular}{|c|c|c|c|c|c|c|c|}
\hline $\begin{array}{l}\text { Date } \\
\text { Time }\end{array}$ & $\begin{array}{c}8-16-79 \\
14: 16\end{array}$ & $\begin{array}{c}8-16-79 \\
15: 02\end{array}$ & $\begin{array}{c}8-16-79 \\
15: 48\end{array}$ & $\begin{array}{c}8-23-79 \\
13: 33\end{array}$ & $\begin{array}{c}8-24-79 \\
13: 20\end{array}$ & $\begin{array}{c}8-24-79 \\
14: 20\end{array}$ & $\begin{array}{c}8-24-79 \\
15: 23\end{array}$ \\
\hline Bed temperature, ${ }^{\circ} \mathrm{F}$ & 1519 & 1500 & 1520 & 1470 & 1470 & 1478 & 1480 \\
\hline Superfizial velocity, ft/sec & 5.0 & 5.1 & 5.2 & 4.1 & 4.1 & 4.1 & 4.2 \\
\hline Static bed depth, inches & .28 & 30 & 30 & 32 & 36 & 36 & 37 \\
\hline Coal feed rate, $1 \mathrm{~b} / \mathrm{hr}$ & 19.4 & 20.7 & 19.7 & 16.1 & 16.3 & 16.3 & 15.8 \\
\hline Limestone feed rate, $1 \mathrm{~b} / \mathrm{hr}$ : & 2.8 & 3.4 & 4.1 & 1.3 & 2.8 & 3.5 & 3.65 \\
\hline Calcium/sulfur, mole ratio & 1.75 & 2.0 & 2.5 & 1.0 & 2.1 & 2.6 & 2.8 \\
\hline Combustion air flow, $1 \mathrm{~b} / \mathrm{hr}$ & 193 & 201 & 202 & 163 & 163 & 162 & 166 \\
\hline $\mathrm{o}_{2}$ in flue gas; percent & 3.3 & 3.4 & 3.8 & 3.5 & 3.8 & 3.65 & 3.8 \\
\hline Indicated excess air, percent & 18.2 & 18.8 & 21.6 & 19.5 & 21.6 & 20.6 & 21.6 \\
\hline Carbon stilization, percent burned & 87.6 & 87.6 & 87.6 & 89.9 & 86.7 & 86.7 & 86.7 \\
\hline $\begin{array}{l}\mathrm{SO}_{2} \text { in flue gas, ppr } \\
\text { Sulfur capture (weight percent remc }\end{array}$ & 675 & 625 & 535 & 880 & 680 & 590 & 530 \\
\hline As-fed coal & 68.4 & 70.6 & 74.2 & 58.4 & 67.2 & 71.8 & 74.4 \\
\hline As-burned coal & 72.0 & 74.8 & 77.0 & 62.8 & 71.6 & 75.5 & 76.6 \\
\hline
\end{tabular}

$\begin{array}{clc}\text { Limestone size: } & 12 \times 30 \text { mesh } \\ \text { Coal analysis: } & \mathrm{C} & 67.66 \% \\ \ldots & \mathrm{H}_{2} \ldots & 4.66 \\ \cdots & \mathrm{O}_{2} & 5.79 \\ & \mathrm{~N}_{2} & 1.33 \\ & \mathrm{H}_{2} \mathrm{C} & 2.33 \\ & \mathrm{~S} & 2.53 \\ & \text { Ast } & 15.7\end{array}$


Table 11.2. AFBC sulfur captire results for August 27-30, -979.

\begin{tabular}{|c|c|c|c|c|c|c|c|}
\hline $\begin{array}{l}\text { Date } \\
\text { Time }\end{array}$ & $\begin{array}{c}8-27-79 \\
13: 47\end{array}$ & $\begin{array}{c}8-27-79 \\
14: 45\end{array}$ & $\begin{array}{c}8-27-79 \\
15: 45\end{array}$ & $\begin{array}{c}8-30-79 \\
13: 02\end{array}$ & $\begin{array}{c}8-30-79 \\
13: 46\end{array}$ & $\begin{array}{c}8-30-79 \\
14: 29\end{array}$ & $\begin{array}{c}8-30-79 \\
15: 16\end{array}$ \\
\hline Bed temperature, ${ }^{\circ} \mathrm{F}$ & 1475 & 1470 & 1468 & 1462 & 1464 & 1472 & 1468 \\
\hline Superficial velocity, ft/sec & 4.0 & 4.0 & 4.0 & 4.0 & 4.0 & 4.1 & 4.1 \\
\hline Static bed depth, inches & 29 & 30 & 32 . & 34 & 34 & 36 & 37 \\
\hline Coal feed rate, $1 \mathrm{~b} / \mathrm{hr}$ & 16.5 & 16.5 & 17.0 & 15.7 & 15.7 & 15.7 & 15.7 \\
\hline Limestone feed rate, $1 \mathrm{~b} / \mathrm{hr}$ & 1.8 & 5.2 & 5.5 & 5.0 & 5.8 & 6.5 & 7.6 \\
\hline Calcium/sulfur, mole ratio & 1.3 & 3.8 & 3.9 & 3.9 & 4.5 & 5.0 & 5.9 \\
\hline Combustion air flow, $1 \mathrm{~b} / \mathrm{hr}$ & 158 & 159 & 158 & 161 & 161 & 163 & 164 \\
\hline $\mathrm{O}_{2}$ in flue gas, percent & 3.3 & 4.3 & 3.25 & 3.8 & 3.95 & 3.3 & 3.8 \\
\hline Indicated excess air, percent & 18.2 & 25.2 & 17.9 & 21.7 & 22.7 & 18.3 & 21.8 \\
\hline Carbon utilization, percent burned & 81.0 & 81.0 & 81.0 & 86.2 & 86.2 & 86.2 & 86.2 \\
\hline $\mathrm{SO}_{2}$ in flue gas, $\mathrm{ppm}$ & 930 & 370 & 260 & 480 & 425 & 465 & 425 \\
\hline Sulfur capture (weight percent remo & & & & & & & \\
\hline As-fed coal & 56.5 & 81.6 & 87.9 & 76.9 & 79.3 & 78.2 & 79.5 \\
\hline As-burned coal & 62.8 & 85.1 & 90.0 & 79.3 & 81.7 & 79.6 & 81.2 \\
\hline
\end{tabular}

$\begin{array}{clc}\text { Limestone size: } & 12 \times 30 \text { mesh } \\ \text { Coal analysis: } & \mathrm{C} & 67.66 \% \\ & \mathrm{H}_{2} & 4.66 \\ & \mathrm{O}_{2} & 5.79 \\ \therefore \quad & \mathrm{N}_{2} & 1.33 \\ & \mathrm{H}_{2} \mathrm{O} & 2.33 \\ & \mathrm{~S} & 2.53 \\ & \text { Ash } & 15.7\end{array}$


Table 11.3. AFBC Sulfur capture results for June.

\begin{tabular}{|c|c|c|c|c|c|c|c|}
\hline $\begin{array}{l}\text { Date } \\
\text { Time }\end{array}$ & $\begin{array}{r}6-8-79 \\
14: 18\end{array}$ & $\begin{array}{r}6-8-79 \\
15: 33\end{array}$ & $\begin{array}{c}6-19-79 \\
14: 25\end{array}$ & $\begin{array}{c}6-25-79 \\
14: 30\end{array}$ & $\begin{array}{c}6-29-79 \\
15: 15\end{array}$ & $\begin{array}{c}6-29-79 \\
15: 35\end{array}$ & $\begin{array}{c}6-29-79 \\
15: 50\end{array}$ \\
\hline Bed temperature, ${ }^{\circ} \exists$ & 1454 & 1426 & 1495 & 1533 & 1513 & 1533 & 1519 \\
\hline Superficial velocity, ftisec & 5.0 & 4.8 & 4.6 & 5.9 & 5.1 & 5.1 & 5.2 \\
\hline Static bed depth, inches & 21 & 24 & 19.5 & 25 & 31 & 31 & 31 \\
\hline Coal feed rate, $1 \mathrm{~b} / \mathrm{hr}$ & 22.7 & 22.4 & 20.9 & 27.5 & 22.4 & 23.9 & 23.9 \\
\hline Limestone feed rate, $1 \mathrm{~b} / \mathrm{hr}$ & 7.5 & 7.9 & 7.6 & 7.5 & 5.8 & 5.8 & 5.8 \\
\hline Calcium/sulfur, mole ratio & 4.0 & 4.3 & 4.4 & 3.3 & 3.1 & 2.9 & 2.9 \\
\hline Combustion air flow, $1 \mathrm{~b} / \mathrm{hr}$ & 202 & 194 & 182 & 225 & 199 & 198 & 203 \\
\hline $\mathrm{O}_{2}$ in flue gas, percent & 3.4 & 4.0 & 3.85 & 2.12 & 3.35 & 2.68 & 2.65 \\
\hline Indicated excess air, Fercent & 18.9 & 23.1 & 22.0 & 11.0 & 18.6 & 14.3 & 14.1 \\
\hline Carbon utilization, percent burned & 73.8 & 73.8 & 73.2 & 73.0 & 79.0 & 79.0 & 79.0 \\
\hline $\mathrm{SO}_{2}$ in flue gas, ppm & 160 & 140 & 230 & 170 & 260 & 270 & 270 \\
\hline \multicolumn{8}{|c|}{ Sulfur capture (weight percent removed): } \\
\hline As-fad coal & 92.5 & 93.2 & 88.9 & 92.6 & 87.9 & 87.8 & 87.9 \\
\hline As-biarned coal & 94.1 & $95: 0$ & 91.7 & 94.4 & 90.6 & 91.2 & 90.8 \\
\hline
\end{tabular}

\begin{tabular}{lll}
\hline Limestone size: & $12 \times 30$ mesh \\
Coal analysis: & $\mathrm{C}$ & $67.66 \%$ \\
& $\mathrm{H}_{2}$ & 4.66 \\
& $\mathrm{O}_{2}$ & 5.79 \\
& $\mathrm{~N}_{2}$ & 1.33 \\
& $\mathrm{H}_{2} \mathrm{O}$ & 2.33 \\
& $\mathrm{~S}$ & 2.53 \\
& Ash & 15.7
\end{tabular}


data which indicates sulfur capture is better at $1500^{\circ} \mathrm{F}$ and worse at $1600^{\circ} \mathrm{F}$ for the $6-\mathrm{ft} / \mathrm{sec}$ case. The carbon burnup for this series of tests was about $83 \%$. This is reasonable when shallow beds with no recycle of char are considered.

For the $5 \mathrm{ft} / \mathrm{sec}$ series of tests, bed temperatures were held to $1500^{\circ} \mathrm{F}$. A calcium to sulfur mole ratio of just over $3: 1$ is required for $90 \%$ sulfur capture. Carbon burnup was about $86 \%$.

For the test series at $4 \mathrm{ft} / \mathrm{sec}$, the bed temperature was limited to $1470^{\circ} \mathrm{F}$ due to the temperature on the surface of the bed exchanger tubes. The bulk of the sulfur capture results lie between the 5 and $6 \mathrm{ft} / \mathrm{sec}$ data. This phenomenon is not completely understood but is attributed to both the lower temperature and the possibility of poor mixing at the lower velocity. This effect will be studied next month. Carbon burnup for the $4 \mathrm{fc} / \mathrm{sec}$ tests averaged $86 \%$.

During August the fluldized bed was successfully ignited with hot air at $760^{\circ} \mathrm{F}$. Apparently the volatile material ignites at this point while the fixed carbon accumulates in the bed. At about $950^{\circ} \mathrm{F}$, the percent oxygen in the flue gas begins to dramatically decrease, indicating complete ignition of the accumulated remainder of the coal.

Particle densities of the bed material were measured at 70 to $75 \mathrm{lb} /$ cu. ft during the August testing.

One of the combustion runs during August was terminated after $1-1 / 2$ hours due to complete power failure inside the building. Since the combustion air is supplied by the plant system, no problems were encountered with either bed slumping or slagging despite loss of all instrument. readings.

Troblems have continucd to ocour with draining of hot bed material. Apparently the problems are caused by the characteristic type of ball valve used to control the flow of solids. Differential expansion of the ball and seat has caused the valve to stick in the open position on three occasions. This problem has been circumvented during these short tests by performing most bed drains at room temperature prior to preheat and ignition.

Early in August a gas cylinder was filled with a mixture of $\mathrm{SO}_{2}$ and nitrogen gases so that the operation of the $\mathrm{SO}_{2}$ meter could be checked without repeating the entire recalibration process. It is believed that good, consistent data has been obtained with this method.

An electric vibrator was added to the coal hopper early in the month. This modification has resulted in a much needed improvement in the uniformity of the coal feeding process.

At the end of August, 33 drums of limestone and 100 drums of coal were received from TVA. A portion of this material will be prepared during September so that testing with TVA materials can begin in October. 
Unfortunately, the coal was wet when it was loaded into the drums. This will make it necessary to dry the coal before it can be crushed or fed to the combustor. This will entail a considerable amount of additional effort and expense in preparing the coal for use.

\subsection{Assessment of the State-of-the-Art of PFBC Systems - Task 6}

R. L. Graves, M. E. Lackey, and A. P. Fraas $^{a}$

\subsubsection{Contract objective}

The purpose of this program is to provide TVA with an assessment and overview of the state-of-the-art for PFBC systems and their associated components.

\section{5 .2 Status summary}

This month's activity consisted of writing the section of the final. report on the state-of-the-art of pressurized fluidized bed combustion dealing with the parametric study of plant efficiency. This section of the report is being submitted to ASME for review and possible application subsequent to the review.

\subsection{Analytical Support and Alternate Design Concepts Evaluation - Task 7 \\ E. C. Fox, C. S. Daw, and R. P. Krishnan}

\subsubsection{Contract objective}

The objectives of this task are to assist TVA in determining the design parameters which are critical to an effective AFBC system from the standpoinls of efficiency, and cost and to provide direction as to better design options.

\section{6 .2 Status summary}

We have completed performance analyses for 16 cases. Case conditions and results are summarized in Tables $11.4,11.5$, and 11.6. Preliminary cunclustons for the cases studied are:

- Couluustion above the bed can have a major impact on the location and area of the heat transfer surfaces (see July monthly).

\footnotetext{
$a_{\text {Consultant }}$
} 
Table 11.4. AFBC with carbon burnup cell

\begin{tabular}{|c|c|c|c|c|c|c|c|c|c|c|c|}
\hline \multicolumn{7}{|c|}{ Main Bed } & \multicolumn{5}{|c|}{$\mathrm{CBC}$} \\
\hline & $\mathrm{T}$ & & v & Ho & E.A. & $\alpha$ & $\mathrm{T}$ & & v & Ho & E.A. \\
\hline 1 & $1550^{\circ} \mathrm{F}$ & 8 & $\mathrm{ft} / \mathrm{sec}$ & $4 \mathrm{ft}$ & $20 \%$ & .85 & $1800^{\wedge} \mathrm{F}$ & 8 & rL/sec & $4 \mathrm{ft}$ & $20 \%$ \\
\hline 2 & $1550^{\circ} \mathrm{F}$ & $G$ & $f t / s \in c$ & $4 \mathrm{ft}$ & $20 \%$ & .85 & $1800^{\circ} \mathrm{F}$ & 8 & $\mathrm{ft} / \mathrm{sec}$ & $4 \mathrm{It}$ & $20 \%$ \\
\hline 3 & $1550^{\circ} \mathrm{F}$ & 4 & $\mathrm{ft} / \mathrm{sec}$ & $4 \mathrm{ft}$ & $20 \%$ & .85 & $1800^{\circ} \mathrm{F}$ & 8 & $\mathrm{ft} / \mathrm{sec}$ & $4 \mathrm{ft}$ & $20 \%$ \\
\hline 4 & $1550^{\circ} \mathrm{F}$ & 8 & fr/sec & $0 \mathrm{ft}$ & $20 \%$ & .85 & $1800^{\circ} \mathrm{F}$ & 8 & fth/sec & $4 \mathrm{ft}$ & $20 \%$ \\
\hline 5 & $1550^{\circ} \mathrm{F}$ & 6 & $\mathrm{ft} / \mathrm{sec}$ & $6 \mathrm{ft}$ & $20 \%$ & .85 & $1800^{\circ} \mathrm{F}$ & 8 & $\mathrm{ft} / \mathrm{sec}$ & $4 \mathrm{ft}$ & $20 \%$ \\
\hline 6 & $1550^{\circ} \mathrm{F}$ & 4 & $\mathrm{ft} / \mathrm{sec}$ & $6 \mathrm{ft}$ & $20 \%$ & .85 & $1800^{\circ} \mathrm{F}$ & 8 & $\mathrm{ft} / \mathrm{sec}$ & $4 \mathrm{ft}$ & $20 \%$ \\
\hline 7 & $1550^{\circ} \mathrm{F}$ & 6 & $\mathrm{ft} / \mathrm{sec}$ & $3 \mathrm{ft}$ & $20 \%$ & .85 & $1800^{\circ} \mathrm{F}$ & 8 & $\mathrm{ft} / \mathrm{sec}$ & $4 \mathrm{ft}$ & $20 \%$ \\
\hline 8 & $1550^{\circ} \mathrm{F}$ & 4 & $\mathrm{ft} / \mathrm{sec}$ & $4 \mathrm{ft}$ & $10 \%$ & .85 & $1800^{\circ} \mathrm{F}$ & 8 & $\mathrm{ft} / \mathrm{sec}$ & $4 \mathrm{ft}$ & $20 \%$ \\
\hline 9 & $1550^{\circ} \mathrm{F}$ & 4 & $\mathrm{ft} / \mathrm{sec}$ & $4 \mathrm{ft}$ & $3 \%$ & .85 & $1800^{\circ} \mathrm{F}$ & 8 & $\mathrm{ft} / \mathrm{sec}$ & $4 \mathrm{ft}$ & $20 \%$ \\
\hline 10 & $1550^{\circ} \mathrm{F}$ & 4 & $\mathrm{ft} / \mathrm{sec}$ & $4 \mathrm{ft}$ & $20 \%$ & .85 & $1650^{\circ} \mathrm{F}$ & 8 & $\mathrm{ft} / \mathrm{sec}$ & $4 \mathrm{ft}$ & $20 \%$ \\
\hline 11 & $1550^{\circ} \mathrm{F}$ & 4 & ft/ gec & $4 \mathrm{ft}$ & $20 \%$ & .85 & $1800^{\circ} \mathrm{F}$ & 4 & $\mathrm{ft} / \mathrm{sec}$ & $4 \mathrm{ft}$ & $20 \%$ \\
\hline
\end{tabular}

IA Case 1 conditions with $\alpha=1.0$

IB Case 1 conditions with $\alpha=0.95$

1C Case 1 conditions with $\alpha=0.90$

1D Case $I$ conditions with $\alpha=0.80$

$1 E$ Case 1 conditions with $\alpha=0.75$

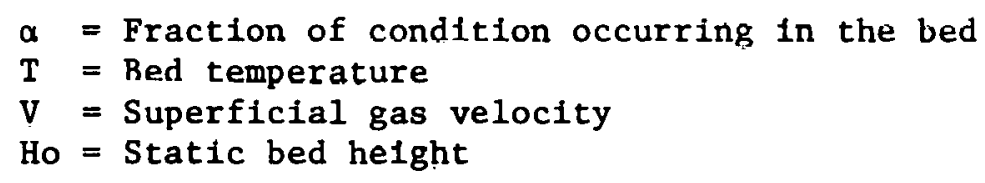


Table 11.5. Results of AFBC performance analysis.

\begin{tabular}{|c|c|c|c|c|c|c|c|c|c|}
\hline Case & $\begin{array}{c}\text { Void fraction } \\
\text { in no tube } \\
\text { zone }\end{array}$ & $\begin{array}{l}\text { Void fraction } \\
\text { in tube zone }\end{array}$ & $\begin{array}{l}\text { Expanded } \\
\text { bed } \\
\text { height } \\
\text { (ft) }\end{array}$ & $\begin{array}{l}\text { Transport } \\
\text { disengaging } \\
\text { height } \\
\text { (ft) }\end{array}$ & $\begin{array}{l}\text { Fraction of } \\
\text { limestone } \\
\text { elutriated }\end{array}$ & $\begin{array}{l}\text { Main bed } \\
\text { combustion } \\
\text { efficiency }\end{array}$ & $\begin{array}{l}\mathrm{Ca} / \mathrm{S} \\
\text { ratio }\end{array}$ & $\begin{array}{c}\text { CBC } \\
\text { combustion } \\
\text { effictency }\end{array}$ & $\begin{array}{c}\text { Overall } \\
\text { boiler } \\
\text { efficiency }\end{array}$ \\
\hline 1 & 0.695 & 0.745 & 7.15 & 10.20 & 0.203 & 0.952 & 2.73 & 0.999 & 0.870 \\
\hline 2 & 0.637 & 0.682 & 6.06 & 8.37 & 0.167 & 0.941 & 2.68 & 0.999 & 0.870 \\
\hline 3 & 0.567 & 0.604 & 5.11 & 6.41 & 0.132 & 0.948 & 2.49 & 0.999 & 0.873 \\
\hline 4 & 0.695 & 0.745 & $10.8 \mathrm{~J}$ & 10.20 & 0.203 & 0.973 & 2.23 & 0.999 & 0.877 \\
\hline 5 & 0.638 & 0.682 & 9.10 & 8.36 & 0.167 & 0.957 & 2.21 & 0.999 & 0.876 \\
\hline 6 & 0.567 & 0.604 & 7.65 & 6.41 & 0.132 & 0.954 & 2.11 & 0.999 & 0.877 \\
\hline 7 & 0.638 & 0.682 & $4.5 \dot{4}$ & 8.36 & 0.167 & 0.931 & 3.18 & 0.999 & 0.864 \\
\hline 8 & 0.567 & 0.604 & 5.11 & 6.41 & 0.132 & 0.944 & 2.50 & 0.999 & 0.876 \\
\hline 9 & 0.567 & 0.604 & 5.11 & 6.41 & 0.132 & 0.940 & 2.50 & 0.999 & 0.878 \\
\hline 10 & 0.567 & 0.604 & 5.11 & 6.41 & 0.132 & 0.948 & 2.49 & 0.992 & 0.872 \\
\hline 11 & 0.567 & 0.604 & 5.11 & 6.41 & 0.132 & 0.948 & 2.49 & 0.999 & 0.873 \\
\hline $1 \mathrm{~A}$ & 0.695 & 0.745 & 7.15 & 10.20 & 0.203 & 0.952 & 2.73 & 0.999 & 0.870 \\
\hline $1 B$ & 0.695 & 0.745 & 7.15 & 10.20 & 0.203 & 0.952 & 2.73 & 0.999 & 0.870 \\
\hline $1 C$ & 0.695 & 0.745 & 7.15 & 10.20 & 0.203 & 0.952 & 2.73 & 0.999 & 0.870 \\
\hline $1 \mathrm{D}$ & 0.695 & 0.745 & 7.15 & 10.20 & 0.203 & 0.952 & 2.73 & 0.999 & 0.870 \\
\hline$I E$ & 0.695 & 0.745 & 7.15 & 10.20 & 0.203 & 0.952 & 2.73 & 0.999 & 0.870 \\
\hline
\end{tabular}


Tab1e 11.6. Resuitt: of AFBC Performance Analys1s

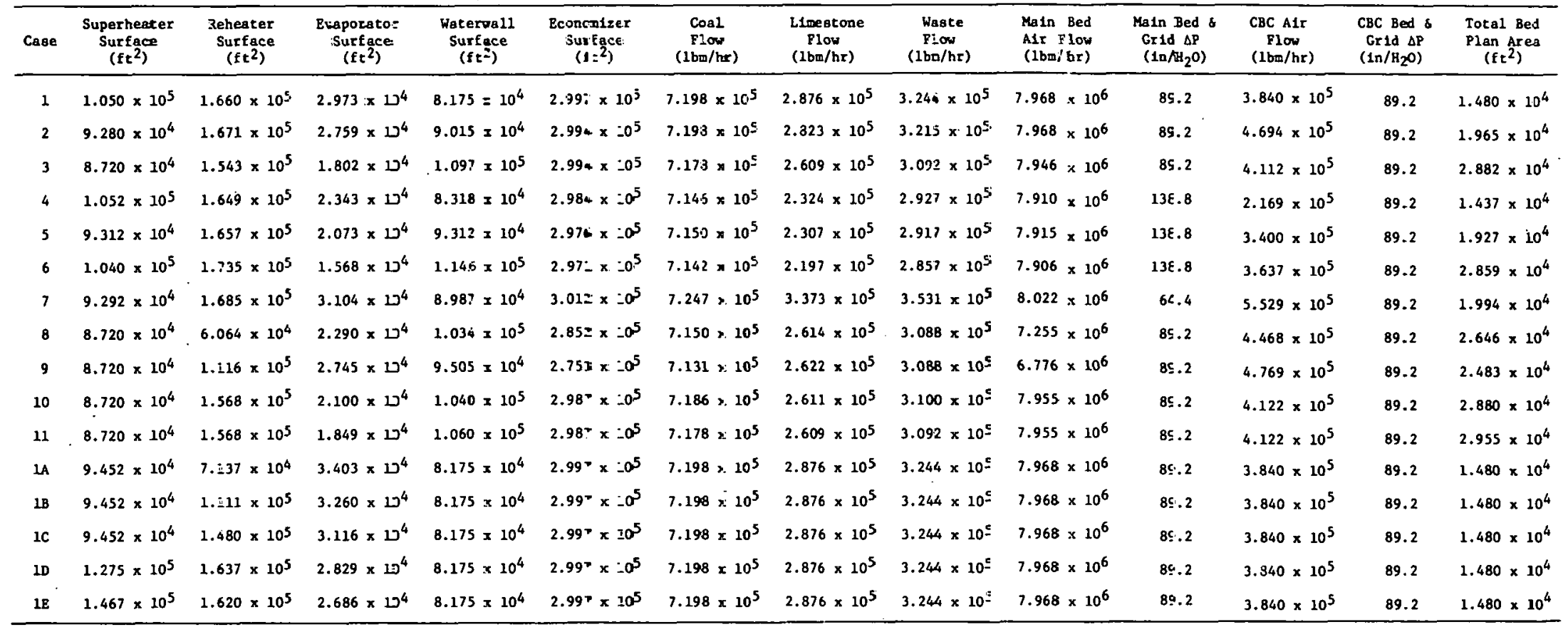


- Bed depth is very important in combustion efficiency and sulfur capture. Reducing the static bed depth from 6 to $3 \mathrm{ft}$ reduced combustion efficiency about $3 \%$ and increased limestone requirements almost $50 \%$.

- Velocity changes have a relatively minor effect on operation. The primary result of higher velocity is greatly reduced plan area.

- Reducing excess air increases overali boiler efficiency, increases the maximum freeboard temperature, and decreases combustion efficiency. Cutting excess air from $20 \%$ to $3 \%$ increased boiler efficiency by $0.65 \%$, increased the maximum freeboard temperature from $1945^{\circ} \mathrm{F}$ to $2003^{\circ} \mathrm{F}$, and decreased main bed combustion efficiency from $94.8 \%$ to $94.0 \%$.

Overall, bed depth and freeboard combustion appear to be the most. important parameters evaluated to date. Further performance evaluations will include variations in limestone and coal properties, operation without a $\mathrm{CBC}$ or recycle, operation with recycle in place of a $\mathrm{CBC}$, and a sensitivity analysis of the effects of uncertainty in the $B \& W$ correlations for combustion efficiency, sulfur capture, and elutriation.

Economic evaluations are now being completed for the first 16 cases.

\subsection{AFBC Technical Source Book and R\&D Evaluation - Task 8}

M. Siman-Tov and A. A. Khan

\subsubsection{Contract objective}

The objectives of this program are: 1) to develop a single comprehensive cource book of technical. data for design procedures and evaluation of AFBC facilities and programs, 2) to review and evaluate existing and proposed AFBC facilities to perform research and development for TVA, and 3) to interpret and translate results of test studies performed for TVA and further the knowledge in AFBC research and development activities.

\section{7 .2 Status summary}

Heat transfer correlations. were reviewed this month for immersed tube bundles inside the fluidized hed. It was concluded that the following correlations gave reliable estimates for the heat transfer coefficient. 
1. The outside convective heat transfer coefficient is given by Andeen and Glicksman's modification of Vreedenberg's equation. For single horizontal tube,

$$
\left(h_{c} d_{t} / K_{g}\right) / P r^{0.3}=900(1-e)\left[\left(G d_{t} p / p_{g} \mu\right)\left(\mu^{2} / d_{p}^{3} \rho_{p}^{2} g\right)\right] \text {, }
$$

where:

$h_{c}=$ single tube convection coefficient, $\mathrm{Btu} / \mathrm{hr}-\mathrm{ft}{ }^{2}-{ }^{\circ} \mathrm{F}$,

$d_{t}^{c}=$ tube $0 D, f t$,

$\mathrm{K}_{\mathrm{g}}^{\mathrm{t}}=$ gas thermal conductivity, Btu/hr-ft ${ }^{2}-{ }^{\circ} \mathrm{F} / \mathrm{ft}$,

$\mathrm{Pr}=$ Prandt 1 number $=\mathrm{Cg} \mu / \mathrm{K}$,

$\mu=$ viscosity of gas, $1 \mathrm{~b} / \mathrm{f} / / \mathrm{hr}$,

$\mathrm{e}=$ void fraction in bed, dimensionless,

$G=$ mass flow rate, $1 b / h r-f t^{2}$,

$\mu_{p}=$ time density of bed material, $1 \mathrm{~b} / \mathrm{ft}^{3}$,

$\rho_{\mathrm{g}}=$ gas density, $1 \mathrm{~b} / \mathrm{ft}$,

$d_{p}=$ average particle size ${ }^{\text {in bed }} \mathrm{ft}$,

$\stackrel{\mathrm{p}}{\mathrm{g}}=$ constant $=4.173 \times 10^{8} \mathrm{ft} / \mathrm{hr}^{2}$,

$\mathrm{Vg}=$ superficial bed velocity, $\mathrm{ft} / \mathrm{hr}$.

2. Radiant portion for outside heat transfer surface coefficient is given by,

$$
h_{r}=\frac{0.173 E\left[\left(T_{B} / 100\right)^{4}-\left(T_{W} / 100\right)^{4}\right]}{T_{B}-T_{W}} \text {. }
$$

where:

$h_{\mathrm{f}}=$ radiant heat transfer coefficient, Btu/hr-ft ${ }^{2}-{ }^{\circ} \mathrm{F}$,

$E \equiv$ overal1 effective cmissivity -0.80 ,

${ }^{\prime} \mathrm{I}_{\mathrm{B}}=$ bed temperature, ${ }^{\circ} \mathrm{R}$,

$\mathrm{I}_{\mathrm{W}}^{\mathrm{B}}=$ external tube wa11 temperature.

3. Overall outside heat transfer coefficient,

$$
\mathrm{U}=\mathrm{h}_{\mathrm{c}} \mathrm{F}_{\mathrm{A}}+\mathrm{hr} \text {, }
$$

where:

$\mathrm{U}=$ outside of bundle heat transfer coefficient, Btu/hr=ft ${ }^{2}-{ }^{\circ} \mathrm{F}$

$F_{A}=$ tube arrangement factor,

$$
F_{A}=\left\{1-\frac{1}{\left(S_{1} / D\right)}\left[1+\frac{1}{\left(S_{11} / D\right)+1}\right]\right\}
$$

where $S_{1}$ and $S_{11}$ are the horizontal p1tch and the vertical pitch, respectively. 
For particles whose average size is greater than $1 \mathrm{~mm}$, the Glicksman Decker equation gives a better estimate for $h_{c}$.

Glicksman Decker Equation

$$
\frac{h_{c} d_{p}}{K_{g}}=(1-\delta)\left[9.42+0.042 \mathrm{v}_{g} d_{p} p\left({ }_{g} c_{g} / K_{g}\right){ }_{g}\right] \text {, }
$$

where $\delta$ is the bubble fraction volume in the bed.

Other considerations affecting the heat transfer coefficient that have been reviewed this month are:

1. flattening the tubes,

2. adding fins on tubes,

3. slanting the tubes, and

4. particle size.

The first version of the fluidization section is almost complete. The details of the subsections were presented in last month's report. The fluidization section will be reviewed with Henry Withers of TVA during the coming month.

\subsection{Materials Support for TVA Pilot and Demonstration AFBC Plants - Task 9}

T. G. Godfrey: J, H. DeVan, R, H. Cooper, and R. A. Bradley

\section{8 .1 Contract objective}

ORNL proposes to assist TVA technically in the materials area. The unique part of an AFBC is the fluidized bed combustor and its associated hardware, since the balance of the plant closely resembles a conventional pulverized-coal supply system. The principal areas of concern are the in-bed heat-exchanger tubes and hangers, the air distributor, side walls, coal feed lines and nozzles, spent-bed removal hardware, and cyclones for separating elutriated material.

\section{8 .2 Status summary}

Review of Proposals for 20-MW(e) AFBC Pilot Plant: The proposals submitted to TVA by Babcock and Wilcox (B\&W) and Combustion Engineering:(CE) for the AFBC pilot plant were reviewed in terms of materials requirements and selections, and the comments were forwarded to the ORNL/TVA Program Manager for incorporation into the overall review package. In general, neither bidder adequately addressed potential problem areas with respect to materials; however, this is primarily a reflection of a lack of definitive information regarding response of materials to potential environments in an $\mathrm{AFBC}$. 
In most respects. B\&W took the approach that the pilot plant would be an oversize laboratory unit much like their 6-ft $x$ 6-ft AFBC in Alliance, whereas CE considered it to be a small-scale demo plant. These views lead to quite different designs, particularly in the area of instrumentation and controls. However, both bidders based their boiler material selections on the standard specifications which have evolved for conventional coal-fired convection-pass boilers. Interestingly enough, $B \& W$ took a very conservative position on the distributor plate, while CE took an equally conservative position on the in-bed hangers and supports. Neither design was clearly superior in all respects: A compromise between the two might yield the most desirable pilot plant.

Examination of EPRI/Leatherhead 1000-h AFBC Heat Exchanger Specimens: Metallographic examination of the specimens from the first 1000-h test in the 1.1-m (43-in) diam AFBC at Leatherhead, England, has continued. Spool pieces of alloys, which ranged in composition from $1-1 / 4 \%$ chromium - $1 / 2 \%$ molybdenum steels to high-nickel alloys, were welded to form inbed tubes that were steam-cooled to temperatures over the range 480 to $650^{\circ} \mathrm{C}\left(900\right.$ to $\left.1200^{\circ} \mathrm{F}\right)$ for most of the 1000 -h test. The specimen identification and recorded temperatures are shown in Table 11.7. During the test there were two significant system failures. At $620-\mathrm{h}$, a steam tripout caused a significant specimen temperature rise to occur over a period of about 15 minutes as reflected in the last column of Table 11.7. Earlier, at 590-h, a total electrical failure shut the system down (slumped the hot bed) for a period of two hours. Subsequent inspection of the specimens revealed no visible damage and a later simulation test indicated that the metal temperatures declined rapidly upon a power failure if steam flow was maintained for a short time (40 minutes).

A $1.5 \%$ sulfur coal, Pittsburgh No. 8 , was used with a $\mathrm{Ca} / \mathrm{S}$ ratio of about nine which resulted in a stack gas $\mathrm{SO}_{2}$ level of $100 \mathrm{ppm}$ or lower. The high limestone feed rate was required in order to maintain the desired bed level in the low-freeboard system.

Metallographic examinations show that, in general, the sulfate deposits are unusually thick on the chrome-moly steels, probably caused by the relatively low exposure temperature and high thermal conductivity of the ferritic steels. Beneath the oxide-metal interface are numerous small inclusions of manganese sulfides that are exposure related, while thri:oughout the alloy are other sulfide inclusions that are indigenous to the as-received alloy. The stainless steels show much thinner sulfate deposits, thin continuous oxide scale, and subsurface sulfide inclusions to depths of about $20 \mu \mathrm{m}$. The type $304 \mathrm{H}$ stainless steel seems to have an abnormally high number of indigenous inclusions. The nickel alloys, Inconel 601 and. Incoloy $800 \mathrm{H}$, show the same general features as the stainless steels, with the Incoloy possibly having a higher and more localized concentration of subsurface sulfides. At this time, it is not apparent that the corrosion of any specimen is positional or orientation dependent, although the temperatures reported in Table 11.7 indicate that the top (downstream) side of the samples was hotter than the bottom. 
Table 11.7. Specimen identification and exposure temperatures for the first 1000-h test in the Leatherhead AFBC.

\begin{tabular}{|c|c|c|c|c|}
\hline Specimen & Alloy & $\begin{array}{l}\text { Average } \\
\text { temperature } \\
{ }^{\circ} \mathrm{C}\left({ }^{\circ} \mathrm{F}\right)\end{array}$ & $\begin{array}{l}\text { Standard } \\
\text { deviation } \\
{ }^{\circ} \mathrm{C}\left({ }^{\circ} \mathrm{F}\right)\end{array}$ & $\begin{array}{c}\text { Maximum } \\
\text { temperature } \\
{ }^{\circ} \mathrm{C}\left({ }^{\circ} \mathrm{F}\right)\end{array}$ \\
\hline $\mathrm{A}-0 *$ & $1-1 / 4 \mathrm{Cr}-1 / 2 \mathrm{Mo}$ & 534 (993) & $9(17)$ & $639(1081)$ \\
\hline$A-180$ & $1-1 / 4 \mathrm{Cr}-1 / 2 \mathrm{Mo}$ & $457(856)$ & $8(14)$ & $507(946)$ \\
\hline $\mathrm{B}-180$ & $1-1 / 4 \mathrm{Cr}-1 / 2 \mathrm{Mo}$ & $522(972)$ & $8(15)$ & $557(1036)$ \\
\hline$C-180$ & $2-1 / 4 \mathrm{Cr}-1 \mathrm{Mo}$ & $545(1013)$ & $9(17)$ & $578(1071)$ \\
\hline$D-180$ & $11 \mathrm{Cr}-1 \mathrm{Mo}$ & $542(1009)$ & 11 (19) & $583(1081)$ \\
\hline$E-90$ & 304 H SS & 597 (1107) & 8 (15) & $650(1202)$ \\
\hline$E-270 * *$ & $304 \mathrm{H} \mathrm{SS}$ & $593(1100)$ & - & - \\
\hline$F-180$ & 347 SS & $592(1098)$ & 11 (19) & $633(1171)$ \\
\hline$G-180 * * *$ & $304 \mathrm{H} \mathrm{SS}$ & $563(1044)$ & - & - \\
\hline $\mathrm{H}-\mathrm{O}$ & $\mathrm{I}-800 \mathrm{H}$ & $639(1182)$ & 11 (19) & $683(1261)$ \\
\hline $\mathrm{H}-180$ & $\mathrm{I}-800 \mathrm{H}$ & $590(1092)$ & $12(22)$ & $624(1153)$ \\
\hline $\mathrm{J}-180$ & $310 \mathrm{sS}$ & $618(1142)$ & 11 (19) & $644(1191)$ \\
\hline $\mathrm{K}-180$ & 347 SS & $630(1164)$ & $9(17)$ & $673(1242)$ \\
\hline$L-180$ & $\mathrm{I}-800 \mathrm{H}$ & $615(1139)$ & 11 (19) & $668(1234)$ \\
\hline$M-90$ & $I-601$ & 648 (1197) & $10(18)$ & $678(1251)$ \\
\hline$M-270 * * *$ & $I-601$ & 657 (1205) & - & - \\
\hline
\end{tabular}

* Number is circumferential orientation of thermocouple on specimen (0. on top)

** Not on data logger: used for control

*** Faulty thermocouple 
While the observation of corrosion features to depths of about $20 \mu \mathrm{m}$ in a 1000-h test might seem alarming, it should be noted that other tests have indicated that corrosion of these and similar alloys in AFBC's is initially rapid, but decreases with time. The kinetics appear to be parabolic for the type of corrosion observed in these samples where the oxide scale is adherent and protective, and the subsurface manganese sulfides are considered to be innocuous.

Examination of these specimens will continue with measurements of corrosion penetrations and microprobe analyses. The samples removed at the end of the second 1000-h have now been received and will be examined in the near future. This new set is comprised of corrosion markers of Incoloy $800 \mathrm{H}$ exposed for the full 2000 huurs; coupons of two varieties of alloys exposed for the final 1600 hours; and two steam-cooled specimen probes like the first, one exposed for the secund 1000-h test and one for the entire 2000-h period. No unusual events were reported during the second 1000-h test.

\subsection{Dynamic Modeling of the TVA Fluidized Ded Combuotion Pilot Plant - Task 10}

0. L. Smith

\subsubsection{Contract objective}

The objective of this task is to provide dynamic modeling and transient systems analysis directly applicable to the TVA p1luL plant. As an Important benefit, the information obtainable from a dynamic model would help in the specification of such features as function, range, and type of instrumentation required to provide the desired plant uperating characteristics.

\section{9 .2 Status summary}

A portion of this month was devoted to reviewing the vendors' proposais for the TVA pilul plant. A number of observations and recommendations related to the instrumentation and controls sections were submitted to TVA for consideration. The bidder's digital computer software and hardware seemed unduly generous, and it appeared that a streamlined version might be more cost-effectlve. On the otherhand, some of the proposed Instrumentiation seemed Spartan, and additions were suggested. In some instances, the two proposals appeared to be in disagreement on fundamental system behavior and control requirements. It was suggested that the differences needed to be reconciled between the vendors, or else the pilot plant should be made sufficiently flexible to investigate both alternatives. These and other points were detailed in the written review submitted to TVA. 
As time permitted, development of an $\mathrm{SO}_{2}$ capture submodel for the dynamic modeling work was undertaken. Detalls will be reported next month, when the submodel is expected to be completed.

\subsection{References}

1. D. Merrick and J. Highley, AIChE Symposium Series, No. 137, Vol. 70, pp. 366-378, 1974.

2. "B\&W Quarterly Technical Progress Report for Period of January through March 1979," LR:79:4775:01, 1979.

3. D. Geldart, "Advanced Fluidization," Center for Professional Advancement, Somerville, New Jersey, 1979.

4. R. A. Newbt, N. H. Ulerich, E. P. O'Neill, D. F. Cililerti, and D. L. Heairns, "Effect of $\mathrm{SO}_{2}$ Emission Requirements on Fluidized Bed Combustion Systems," EPA-600/7-78-163, p. 148, 1978.

5. C. Y. Wen and S. Dutta, AIChE Symposium Series, Nō. 161, Vo1. 73, 1977. 


\title{
12. COAL COGENERATION/DISTRICT HEATING PLANT ASSESSMENT
}

\author{
M. A. Karnitz and R. L. Graves
}

\subsection{Objective}

The objective of this work is to provide the Fossil Fuel Utilization Division of DOE with an evaluation of the coal-fired closed-cycle gas turbine as a cogeneration power plant specifically for district heating in the Minneapolis-St. Paul area. This entails a preliminary design study, including a cost estimate. The design study is a cooperative effort between ORNL, United Engineers and Constructors (UE\&C), and Northern States Power (NSP). Design of an extraction steam system for the same application is being carried out simultaneously by UE\&C and will allow a comparative evaluation of both cogeneration plants. These design studies are part of a considerably larger program involving other divisions of DOE with the objective of evaluating district heating in Minnoapolio-St. Paul.

\subsection{Status Summary}

In early August, we initiated the contracting procedure with the St. Paul District Heating Development Company. The goal is to have the contract in place by October 1, 1979. During the month of September, the Development Company will start work on the design and implementation plans for a 200-MW hot water district heating system, utilizing the funds provided by the State of Minnesota. They have opened an office in downtown St. Paul and presently have a staff of four people.

M. A. Karnitz attended a DOE District Heating Task Force Meeting on August 7 in Washington D.C. The function of this group is to put together a National District Heating Program. The Task Force is to complete its work by November 1979 .

Editorial work continued on the full Studsvik report, the Building Conversion Study, the District Heating Net Energy Analysis Study, and the District Heating/Cogeneration Symposium Proceedings. It is anticipated that all four of these will be printed during the month of September. We have also started to edit the Power Plant Retrofit Study.

Preliminary performance curves for the two closed-cycle gas turbine systems for district heating were derived. A significant result was the apparent poor fit of a highly recuperated, low-pressure ratio closedcycle turbine to district heating demands: Although the low pressure ratio gives rise to a maximized electric-only efficiency, it also results in a rather low power output. at high thermal loads when inventory control and recuperator bypass are used to shift from power to heat. In fact, the power generation at maximum heat load is about $50 \%$ of what might be expected from a conventional steam cogeneration plant at similar heat load and overall fuel utilization. Although the electric-only efficiency is reduced slightly, it appears that a higher pressure ratio will be necessary to resolve this problem. 
The closed-cycle gas turbine with a steam bottoming cycle displays the characteristics of an extraction steam cogeneration plant. The apparent difference is a slightly higher power output at the same heat load while suffering giving up no advantage in overall fuel utilization to the conventional plant.

A review meeting was held August 21 and 22, 1979, in Philadelph1a at the United Engineers and Constructors (UE\&C) office. Progress reports were given by Northern. States Power (NSP), UE\&C, and ORNL. Most of the economic ground rules for the cogeneration plant assessment have been finalized. UE\&C has received considerable interest from turbine manufacturers after sending out specifications. Most of the response is from foreign manufacturers.

Representatives from Garrett (AiResearch) and Rocketdyne presented their findings and opinions on the closed-cycle gas turbine application at the meeting. ORNL and UE\&C intend to use the results of their studies wherever suitable. 


\title{
13. TECHNICAL SUPPORT TO MAJOR LIQUEFACTION PROJECTS
}

\author{
T. W. Pickel
}

Technical support is being provided for the major liquefaction projects being managed by the Oak Ridge Operations Office of DOE. Current activities are related to the Solvent Refined Coal Demonstration Plant Projects, SRC-I and SRC-II, and the H-Coal Pilot Plant Project. A major part of the current effort is concerned with the review and evaluation of contract deliverables for Phase 0 of the SRC-I and SRC-II projects.

\subsection{SRC Demonstration Plants Design Review}

J. J. Kurtz, J. M. Holmes, A. R. Irvine, W. R. Williams, W. R. Winsbro

\subsubsection{Contract objective}

This activity consists of providing technical assistance to the DOEORO Solvent Refined Coal Projects Office on the SRC-I and SRC-II projects. The SRC-I project involves the design, construction, and operation of a coal liquefaction plant for the production of a clean solid boiler fuel. The SRC-II project is for the production of a clean liquid boiler fuel. The government-funded preliminary design of the SRC-I project is contracted with the Southern Company Services, Inc., (SCS) and the SRC-II project contract is with the Pittsburg and Midway Coal Mining Company $(P \& M)$.

The principal purposes of the SKC projects review and evaluation activities are to provide objective assessments of the contractors' technical progress, identification of potential problems, and critiques of project deliverables.

\subsubsection{Status summary}

Space limitations at the ORNL site necessitated the off-site establishment of two temporary work centers for the review of the SRC projects Phase 0 deliverables. The contracted deliverables for the SRC-I project and the SRC-II project were installed in the respective work centers on August 3 . Teams were designated from a roster of 36 representatives from ORNL technical divisions and UCC-ND Engineering disciplines with specific review and risk assessment responslbilltles for technical, environmental, economic and management proposals presented by the SRC-I and SRC-II contractors. Reviews were initiated on August 6. A preliminary assessment of the review findings was presented to ORO SRC Projects Office representatives on August 10. Preliminary drafts of the technical risk assessment and environmental risk assessment were transmitted to the ORO SRC Projects Office on August 23. Final drafts were transmitted on August 28. 
Review comments, observations, and notes of interest were exchanged with UOP/SDC and transmitted to the SRC Projects office as information for the DOE Evaluation Committee for SRC Projects.

The UCC-ND/ORNL comments on specific project deliverables have been screened for pertinence to the SRC-I and SRC-II project contractors. The pertinent comments are in the process of being prepared for integration with UOP/SDC comments to be transmitted by DOE to the SRC project contractors.

\subsection{Direct Liquefaction R\&D Review}

M. S. Edwards, B. R. Rodgers, C. H. Brown, W. R. Gambill

\subsubsection{Contract objective}

This project is an intensive, short-term assessment of current research and development activities of importance to the SRC Demonstration Project. The assessment includes acquisition and review of published information, discussions with R\&D personnel involved in relevant activities, visits to sites of important R\&D activities, monitoring of critical R\&D operations, accessing, to the extent possible, the proprietary information of importance to the project, and cross-matching $R \& D$ activities to the technical data needs of the industrial partners in the demonstration project. Based on the assessment of R\&D activities against the data needs of the SRC demonstration project, recommendations will be formulated, including: priority of activities; adequacy of the $R \& D$ program; the need for possible acceleration, extension, or redirection of current activities; and possible new activities required beyond the current program.

\subsubsection{Status summary}

The complete draft report, ORNL/TM-6952, "Technical Support to the

SRC Demonstration Project: Assessment of Current Research and Development," has been provided to DUE-URU tor comments, and has been transmitted by ORO to the industrial groups involved in SRC demonstration efforts. Upon receipt of ORO approval, the draft report will be widely distributed, particularly to those institutions whose activities in coal conversion research are described within the report. No other substantive effort has been possible in this area because of the commitment of personnel to the ongoing SRC demonstration plants design review. 


\subsection{SRC Source Data Book}

J. P. Belk, M. H. Culver, J. R. Horton, M. R. Lambert, H. A. Mitche11, B. Niemann, W. R. Reed, J. R. Tate, B. T. Thompson, W. T. Thompson

\subsubsection{Contract objective}

The objective of this project is to develop and to make available in one package an independent source of technical information and data base as an aid to DOE program management and other participants in the DOE program to design, construct, and operate SRC demonstration plants.

\subsubsection{Status summary}

During much of the month of August, the work on this task was directed at technical editing for the first deliverable item in the SRC source honk project. Minor revisions are being made to the content and format prior to review and release. Recent additions to the source book include an introductory section and an appendix on methods of design. Further appendices and an index may be included in future versions of the source book as a help to the users.

Contents of the first deliverable item, besides the introductory section and appendix, include the several sections that are described below.

1. The flowsheets, mass balances, and energy balances section contains flowsheets for the main process areas of both SRC-I and SRC-II processes; the section also includes a partial mass balance for the SRC-I procese, with indesed columns showing flow rate and composition of streams identified on the flowsheets.

2. The SRC-I process equipment information section includes information on the solid-liquid separation equipment, the coal slurry recirculation pump, the waste water treatment plant, incinerators, and flares.

3. The SRC-II process equipment information section includes information on the coal slurry mix tanks, the dissolvers, the atmospheric and vacuum fractionators, the recycle hydrogen cryogenic separator, the slurry preheater, the oxygen plant, and the equipment for acid gas rcmoval and sulfur recovery.

4. A chapter on reliability, maintainability, and availability as these factors pertain to the SRC process is included.

5. A section on safety considerations is included.

6. A chapter on mathematical simulation of the SRC plants and the correlations investigated is included. 
Future revisions and additions of source book material would include further equipment information to cover all major plant components, further development of flow sheets, mass and energy balances, and text for the chapters on process contro1, energy recovery, development needs, and the current data base for the SRC process.

\title{
13.4 SRC Environmental Support
}

\author{
S. G. DeCicco
}

\subsubsection{Contract objectives}

The objective of this project is to provide DOE with program assistance in the performance of environmental assessment functions related to the SRC projects. Assessment functions include review of environmental monitoring programs and results, guidance to DOE's industrial partners in their environmental impact analyses, review of environmental permits and licensing requirements, review of SRC contract deliverables, and providing the lead role in fulfilling DOE's responsibilities under the National Environmental Policy Act (NEPA).

\subsubsection{Status summary}

SRC. Market Penetration Study - At DOE's request, ORNL performed a market penetration study for SRC products. The final document was transmitted to DOE on August 20, 1979. Part of this study involved health and environmental aspects of SRC market penetration. The approach used to address this topic divided the issue into three facets: (1) the industrial health hazards to workers employed in an SRC production plant, (2) the environmental hazards of transporting SRC products (especially accidents and spills), and (3) the environmental effects of end-use combustion of SRC products.

Because SRC technology is in the developmental stage, a definitive treatment of these important topics is years away, as most synfuel documents polnt out. However, these issues are timely and deserve treatment. The approach taken was to bracket the health and environmental risks by comparing SRC products with other commodities in the market place which are more, and less, hazardous. For both the industrial hygiene and transportation issues we described the hazards involved for SRC products and comparative surrogates, the methods for protecting the workers and the environment from the hazards, and the cost for these protective measures.

For industrial hygiene, SRC plants are compared with petroleum refineries (less hazardous) and plants manufacturing hazardous chemicals such as acrylonitrile. The transportation comparative surrogates were coal, No. 2 distillate fuel oil, and acrylonitrile. 
Preliminary data suggests that the health risks during production and the environmental risks during transportation are apt to be more severe than for petroleum refineries and fuel products and less severe than for hazardous chemical manufacture and transport. Because of the relationship between overall product cost and transportation and industrial hygiene costs, little or no increase in product cost is anticipated from the extra precautions necessary in these areas. Combustion of SRC liquid fuels will probably produce similar environmental effects as petroleum liquids. Combustion of SRC solid fuel will probably meet EPA New Source Performance standards for $\mathrm{SO}_{2}$ only when produced from certain feed coals.

SRC-I and SRC-II Demonstration Projects - Several tasks occurred this month which were common to the two SRC projects. On August 15, a letter of understanding was sent to DOE concerning a revised EIS schedule for the two SRC projects. The current schedule calls for ORNL to transmit preliminary draft EISs to ORO on December 15 for DOE internal revi.ew, and draft EISs to DOE on April 15 for public review and comment. A meeting on this subject was held at DOE-HQ on August 23. Attendees included ORNL, R. C. Martin (ORO), L. Joseph (FE), A. Govan (ET), J. Johnson (FE), J. Nardella (FE), R. Stern (EV), and W. Ichord (EV).

After several internal drafts and comments from DOE and its industrial partners, ORNL sent a draft annotated EIS outline to DOE. This outline follows the Council on Environmental Quality's (CEQ) new regulations governing the format, style, contents, and purpose of EISs. The EISs for the SRC projects will be among the first prepared under these new regulations. ORNL remains active in trying to interpret the way in which these new regulations apply to the SRC projects.

On August 16 ORNL sent letters to DOE identifying the key envirun= mental issues to be addressed in the EISs for the two projects. These were also sent to the industrial partners' environmental subcontractors who will use them in preparing their input to ORNL's EISs. The new CEQ regulations emphasize the treatment of significant issues and the avoidance of irrelevant bulk.

On August 22 our chemical engineer met with Gulf (SRC-II) and Stearns-Roger to advise them on the manner in which to present their plant design, effluent description, and alternative plant design analysis in the environmental report to ORNL.

The SRC-I EIS preparation is experiencing difficulty in that much of the needed process effluent information was not developed during Phase 0 . With the exception of some socioeconomic impacts, most environmental impacts of an operating plant can be traced to a process effluent; thus the importance of these data. Steps have been initiated to obtain the missing data. 
Review of SRC Deliverables - The Fossil Energy Environmental Project was asked to review the SRC-I Task 7 Environmental Analysis Report, and the SRC-II Environmental Suitability, Site Suitability, and Environmental Analysis Reports. The major environmental issues for the demo plant and a future commercial plant were identified and the completeness of the deliverables for evaluating these issues was addressed.

\subsection{SRC Net Energy Analysis}

W. P. Huxtable, K. F. Wu

\subsubsection{Contract objective}

The objective of this project is to evaluate the overall energy efficiency of solvent refined coal (SRC) processes from coal mining to electricity production and delivery. Analysis will consider not only plant efficiency but will also encompasss energy requirements of raw material acquisition, product distribution, plant construction, and other factors.

\subsubsection{Status summary}

A preliminary SRC net energy analysis was completed several months ago. An initial draft report covering the results of our study was also completed. Following an internal review of this draft report, further revisions and explanations were made. The draft report has been expanded into four sections; summary, methodology, assumptions and models, and numerical results. The summary was completed a month ago and has been reviewed and revised. 'l'his past month the section on methodology was completed and is currently being revised. The remaining two sections are now being written and will cover most of the material considered in the initial draft report. Unless major revisions are requested, the report should be completed this coming month.

\subsection{H-Coal Materlals and Technuluğy Review}

R. A. Bradley, K. H. Lin, R. J. Beaver, P. Carlson, V. Guthrie, J. R. Horton, H. A. Mitchell, B. Niemann, L. Parsly, W. R. Reed, R. W. Swindeman

\section{6.i Contract objective and scope}

Overa11. ohjertive - The materials of construction and the coal liquefaction technologies planned for use in the $\mathrm{H}$-Coal Pllot Plant relative to the available data and experiences will be evaluated. The evaluation will attempt to ensure the maximum utilization of the existing information and experiences from other liquefaction pilot plants and PDUs, and to provide the bases for efficient and relfable operation of the plant. 
Scope - The project activities will cover the following five.subjects pertaining to the H-Coal Pilot Plant:

1. materials of construction and potential materials-related problems. in the plant;

2. reliability of critical components in the pilot plant design;

3. potential problems associated with the plant equipment and accessories due to deficiencies in the engineering design;

4. an "incident report" system to distribute information on technical problems;

5. uncommon and/or abnormal operating and maintenance experience from other liquefaction pilot plants, which will be useful to the H-Coal Pilot Plant.

\subsubsection{Status summary}

Review of technical data on H-Coal Pilot Plant - Preliminary review of the following technical information for the $\mathrm{H}$-Coal Pilot Plant was completed:

1. engineering drawings and process flow diagrams (93 total) from HRI and C. E. Lummus,

2. H-Coal mode operation plan,

3. a list of post-mechanical completion capital revisions prepared by ASFI (Ref. 1).

The above information was reviewed (a) to become familiar with the design of the H-Coal Pilot Plant in preparation for the site visit and meeting with the Ashland Synthetic Fuels, Inc., (ASFI) representatives and (b) to determine any additional data required for the Task Force activities.

Meeting with ASFI and tour of H-Coal Pilot Plant - The initial meeting with ASF'L representatives was held on August 2, 1979 , in Catlettsburig, Kentucky. Participants at the meeting included representatives from DOE/ H-Coal Site Representative (1), ASFI (2), and H-Coal Materials and Technology Task Force (7). The primary purpose of the meeting was to coordinate the work of the Task Force with similar activities being performed by ASFI.

The meeting proceeded in a cooperative atmosphere with free exchange of pertinent technical information between representatives of ASFI and UCC-ND/ORNL. R. A. Bradley (ORNL) commenced the meeting by outlining the organization and the goal of the H-Coal Material and Technology Task Force as well as the purpose of the visit. This was followed by presentation 
of the background information on the $\mathrm{H}$-Coal process development by Ray Schutter (ASFI). Also described by Schutter was the extent of ASFI's interaction with SRC pilot plants (Ft. Lewis and Wilsonville), EDS pilot plant and HRI-Trenton PDU. Ray Searles (ASFI) outlined ASFI's ongoing material evaluation program, including development of the failure analysis procedure.

The remainder of the meeting was devoted to discussion of the basis for ASFI's post-mechanical completion capital revisions (Ref. 1) and other pertinent technical issues. A guided tour of the H-Coal Pilot Plant was made after the meeting. The discussion clarified many of the questions raised by the UCC-ND/ORNL representatives. There are, however, a number of technical problems to be evaluated and additional plant technical data to be acquired. Nevertheless, both parties considered the meeting to be mutually beneficial and an important first step in establishing a liaison between the two organizations for future cooperation.

Preparation of revised work statement - The revised work statement describing an action plan for the Task Force in support of the H-Coal project was completed and submitted to DOE-ORO. The work statement reflects the result of the initial meeting with ASFI outlined above. The scope has been reduced and redirected toward a short-term Task Force effort to carry out (a) an independent identification of potential problems associated with materials, equipment and engineering design in the $\mathrm{H}$-Coal Pilot Plant and (b) an independent assessment of the adequacy. of the operating procedures and plans for corrective actions to cope with the problems. The revised action plan now covers the following four tàs $\ddot{k}$ areas:

Task 1. Evaluation of Materials of Construction Planned for Use in H-Coal Pilot Plant Relative to Operating Experience in Other Pilot Plants and PDUs.

Task 2. H-Coal Component Reliability Characteristics with Relation to Fxperience in other Operations.

Task 3. Assessment of Engineering Problems and Significant Operation and Maintenance Experiences in Coal Liquefaction Pilot Plants.

Task 4. Establishment of an "Incident" Report System to Distribute Information on Technical Problems.

Task 3 above represents consolidation and reduction in the scopes of Tasks 3 and 5 described in the previous draft work statement (Ref. 2). 


\subsection{H-Coal Quality Assurance Assistance}

K. K. K1indt

\subsubsection{Contract objective}

The objective of this task is to provide technical support to DOE/SRC in the resolution of weld quality problems in the piping system at the H-Coal Pilot Plant.

\subsubsection{Status summary} plan.

The repair of piping system butt welds is progressing according to .

The socket weld fit-up is the only problem on which total agreement has not been reached. The present proposed plan for base-line and inservice examination of the most critical socket welds has been reviewed and concurred with.

\subsection{References for Section 13}

1. Letter with attachment, J. C. Swan to J. F. Pearson, Jr., "H-Coal "Pilot Plant: Post Mechanical Completion Capital Revisions," No: $\mathrm{AD}-877$, June 14, 1979.

2. Letter with attachment, L. E. McNeese to J. F. Pearson, Jr., "Material and Technology Force," June 21, 1979. 
ORNL/TM-7057 (August)

INTERNAL DISTRIBUTION

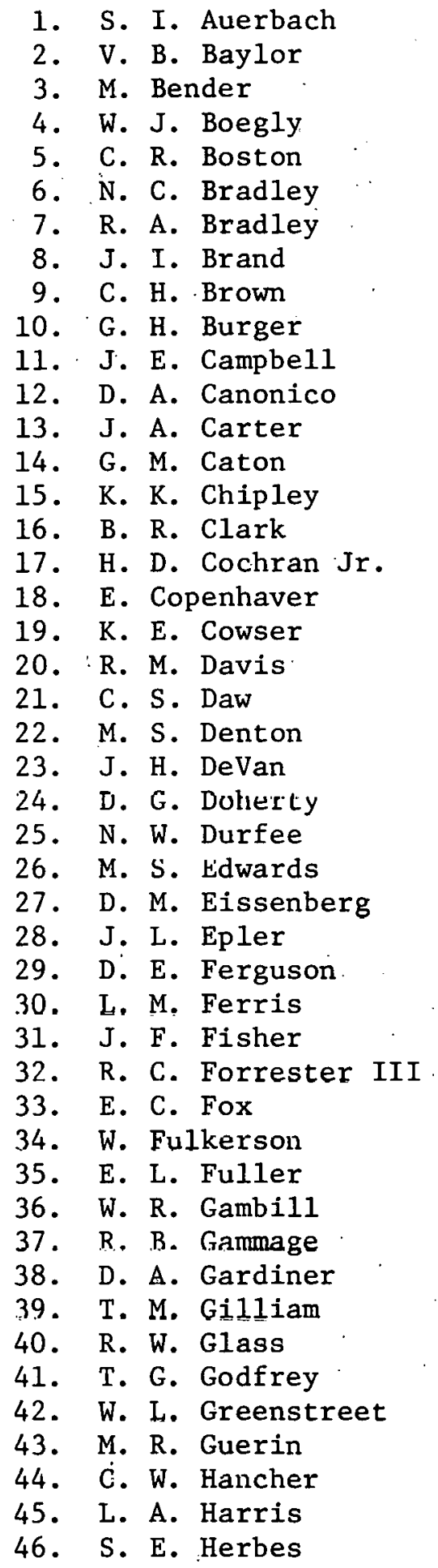

47. J. R. Hightower

48. E. C. Hise

49. R. S. Holcomb

50. A. S. Holman

51. J. M. Holmes

52. J. K. Huffstetler

53. G. R. Jasny

54. R. L. Jolley

55. J. E. Jones Jr.

56. R. R. Judkins

57. J. R. Keiser

58. 0. L. Keller

59. A. D. Kelmers

60. J. A. Klein

61. R. P. Krishnan

62. J. W. Larsen

63. K. H. Lin

64. R. E. MacPherson

65. A. P. Malinauskas

66. G. B. Marrow

67. C. J. McHargue

68-72. L. E. McNeese

73. J. P. Meyer

74. J. E. Mrochck

75. P. Nettesheim

76. B. Niemann

77. L. C. Oakes

78. C. J. Oen

79. G. E. Oswald

80. L. F. Parsly

81-82. T. W. Pickel

83. W. W. Pitt

84. H. Postma

85. M. L. Poutsma

86. D. E. Reichle

87. C. R. Richmond

88. L. W. Rickert

89. B. R. Rodgers

90. M. W. Rosenthal

91. T. H. Row

92. W. L. Russel1

93. A. R. Sadlowe

94. R. Salmon

95. C. Samuels

96. D. D. Schuresko

97. C. D. Scott 
98. W. D. Shults

99. V. K. Sikka

100. M. Siman-tov

101. S. P. N. Singh

102. C. B. Smith

103. G. P. Smith

104. I. Spiewak

105. R. L. Spore

106. J. B. Storer

107. R. A. Strehlow

108. R. W. Swindeman

109. 0. K. Tallent

110. I. L. Thomas

111. V. J. Tennery

112. H. E. Tramel1

113. D. B. Trauger

114. W. C. Ulrich
115. R. I. Van Hook

116. P. R. Vanstrum

117. J. S. Watson

118. J. R. Weir

119. P. R. Westmoreland

120. M. K. Wilkinson

121. D. T. Wilkes

122. L. V. Wilson

123. R. G. Wymer

124. E. L. Youngblood

125. C. S. Yust

126. H. W. Sternberg (Consultant)

127. Patent office

128-132. Laboratory Records

133. Laboratory Recordo - RC

134-135. Central Research Library

136. Document Reference Section

\section{EXTERNAL DISTRIBUTION}

DOE-Oak Ridge Operations

137. Office of Assistant Manager for Research and Development

138. Office of Assistant Manager for SRC Projects

DOE-Denver Project Office, Suite 211, 1075 S. Yukon Street, Lakewood, CO 80226

139. W. L. No11

DOE-Office of Fossil Energy, Washington, DC. 20545

110. W. T. Bakker

141. J. T. Bartis

157. E. Li.evens

142: E. K. Bastrẻss

158. E. A. Lloyd

143. J. D. Batchelor

159. G. V. McGuri

144. D. L. Bauer

160. C. Miller

145. L. M. Burman

161. J. A. Nardella

146. T. B. Cox

162. F. S. Pierce

147. A. Deitz

163. H. E. Podal1

148. R. H. Fischer

149. J. Forst

150. S. I. Freedman

151. G. Fumich

152. R. M. Ham11 con

164. J. L. Powel1

153. R. H. Hertzberg

165. M. D. Shapiro

166. J. Shen

167. A. P. Sikri

168. J. Smith

154. H. Jones

155. L. M. Joseph

169. D. K. Stevens

170. G. E. Voelker

171. J. W. Watkins

156. T. K. Lau

172. H. L. Weisenfeld

173. P. R. Wieber 
DOE-Environment, Washington, DC

174. N. F. Barr

175. R. M. Jimeson

176. W. E. Mott

177. R. W. Wood

Department of Housing and Urban Development, 4517 th St., S.W., Washington, DC 20410

178. G. S. Leighton

179. J. H. Rothenberg

DOE-Morgantown Energy Research Center, P. O. Box 800, Morgantown, W.V. 26506

180-185. The Director (6 copies)

186. W. J. Haggerty

187. J. E. Notestein

188. L. A. Schrïder

189. W. E. Wallace, Jr.

190. J. S. Wilson

DOE-Pittsburgh Energy Technology Center, 4800 Forbes Ave., Pittsburgh, PA 15213

191. B. D. Blaustein

194. R. E. Hucko

192. S. W. Chun

193. A. W. Deurbrouck

195. J. J. Lacey

196: A. G. Sharkey

197-219. Director for J. 0. Barreca

National Science Foundation, 1800 G Street, N.W., Washington, DC 20550

220. Robert Rabin

Tennessee Valley Authority, 440 Commerce Union Bank Building, Chattanooga, TN 37401

221. C. K. Andrews

222. C. E. Ba11

223. M. J. Mayfield

224. W.. T. Newberry

225. H. W. Withers

Tennessee Valley Authority, 1230 Commerce Union Bank Building, Chattanooga, TN 37401

226. J. M. Castleberry

227. Randy M. Cole

228. Barry Goss

229. G. A.'Hollinden

230. Manville J. Mayfield

231. Stephen R. Smith

232. Dona1d C. Thomas

233. Uwe Zitzow

Tennessee Valley Authority, 1300 Commerce Union Bank Building, Chattanooga, TN 37401

234. W. D. Goins

University of Kentucky, Institute for Mining and Minerals Research,

$21.3:$ Bradley Ha11, Lexington, KY 40506

235. Theresa Wiley, Inst1tute Librarlan

236. . O. J. Hahn

237. J. K. Shau 
238. Seymour Alpert, Manager, Process Development Fossil Fue1 Department, Electric Power Research Institute, 3412 Hillview Ave., P. 0. Box 10412, Palo Alto, CA 94304

239. Frank Baranowski, Mechanical Technology Incorporated, Crystal Square 4, Suite 310, Jefferson Davis Highway, Arlington, VA 22202

240. Lou Batta, Union Carbide Corp., 61 E. Park Drive, Tonawanda, N.Y. 14150

241. Harold Beuther, Manager, Synthetic Fuels, Gulf Research and Development Company, P. O. Box 2038, Pittsburgh, PA 15230

242. Prof. Al Bishop, Chemical Engineering Department, University of Pittsburgh,. Pittsburgh, PA 15213

243. N. S. Boodman, U.S. Steel Corp., Applied Research Laboratory, 125 Jamison Lane, Monroeville, PA 15145

244. E. L. Clark, Chemical Engineering Services, 4615 North Park Ave., Chevy Chase, MD 20015

245. Richard C. Corey, Mitre Corporation, Metrek Division, 1820 Dolley Madison B1vd., McLean, VA 22101

246. A. K. Dubberly, 650 S. Cherry St., Suite 400, Denver, Colorado 80222

247. William R. Epperly, Exxon Research and Engineering Company, P.0. Box 101, Florham Park, NJ 07932

248. Dr. R. A. Greenkorn, Chemical Engineering Dept., Purdue University, West Lafayette, IN 47907

249. Jack L. Gregory, Project Manager, TRW Energy Systems, 7600 Colshire Drive, McLean, VA 22101

250. L. R. Harris, National Institute of Occupational Health and Safety, MS 8A-45, 5600 Fishers Lane, Rockville, MD 20857

251. George Heunisch, Research Division of Conoco Coal Development Co., Library, PA 15129

252. Everitt Huffman, Manager of Fuel Processing Programs, Southern Company Services, P. 0. Box 2625, Birmingham, AL 35202

253. Martha Koehler, Bechtel Corp., P. 0. Box 3695, San Francisco, CA 94119

254. Robert W. Laza, Director, Interim Project Office, Department of Energy, Chicago Operations Office, 9800 S. Cass Ave., Argonne, IL 60439

255. W. J. Lochmann, Ra1ph M. Parsons Co., 100 W. Walnut Street, Pasadena, CA 91124

256. Walter McGough, Jr., Tetra Tech., Inc., 1911 N. St. Myer Drive, Suite 601, Arlington, VA 22209

257. Joe Morha11, Heat Research Corporation, 3440 Richmond Ave., Houston, TX 77046

258. Robert J. Novak, ERCO, 5509 Tarrywood Court, Raleigh, NC 27609

259. Thomas E. O'Hare, Department of Energy and Environment, Brookhaven National Laboratory, Associated Universities, Inc., Upton, LI, NY 11973

260. F. N. Peeblec, Dean of Enginccring, University of Tennessee; Knoxville, TN 37916

261. Kenneth P. Lue Phang, Development Engineering Staff, Tennessee Valley Authority, 220 Liberty Building, Knoxville, TN 37902 
262. Dan Rimmer, City Svc. Co., 1305, 4-NB, Box 300, Tulsa, OK 74102

263. Charles B. Sedman, U.S. Environmental Protection Agency, Research Triangle Park, NC 27711

264. Dr. Marion Semchyshen, Director of Research, Materials Research for Molybdenum Development, Climax Molybdenum Research Laboratory, 1600 Huron Parkway, P. 0. Box 1568, Ann Arbor, MI 48106

265. W. R. Siegart, Texaco, Inc., 2000 Westchester Ave., White Plains, NY 10650

266. Carl Streed, Process Research and Development Division, Mobil Research and Development Corporation, Billingsport Road, Paulsboro, NY 08066

267. Prof. C. V. Wen, Chairman, Department of Chemical Engineering, West Virginia University, Morgantown, WV 26506

268. Dr. Wendel Wiser, Department of Mining and Fuels Engineering, University of Utah, Salt Lake City, UT 84112

269-295. Technical Information Center. 